Universidade de Brasília

Instituto de Ciência Política

\author{
Daniel Amaro
}

\title{
Modulando a participação: o potencial democrático das rádios comunitárias
}




\section{Daniel Amaro}

\section{Modulando a participação: o potencial democrático das rádios comunitárias}

Monografia elaborada pelo aluno Daniel Araújo Amaro, matrícula 05/79629, como exigência do curso de graduação em Ciência Política da Universidade de Brasília, sob a orientação do Professor Luis Felipe Miguel. 


\section{Folha de Aprovação}

Trabalho apresentado ao Instituto de Ciência Política da Universidade de Brasília (IPOL/UnB), sob a orientação do Professor Doutor Luis Felipe Miguel e aprovado por:

Prof. Luis Felipe Miguel (IPOL/UnB)

Prof $^{a}$. Flávia Milena Biroli Tokarski (IPOL/UnB) 


\section{Sumário}

Agradecimentos, i

Resumo, ii

Introdução, 1

\section{Capítulo I, 4}

A democracia como uma idéia

\section{Capítulo II, 14}

Análise do discurso parlamentar: o imaginário a respeito das rádios comunitárias

\section{Capítulo III, 28}

A legislação vigente e as perspectivas de avanço

Conclusão, 39

Anexo A, 43

Anexo B, 49

Anexo C, 59

Anexo D, 75

Bibliografia, 92 


\section{Agradecimentos}

Agradeço primeiramente a minha família, por ter me fornecido o suporte necessário para chegar ao fim de mais essa etapa. À Marize Ferreira, mãe querida e dedicada, fonte de bom senso, que me ensinou a ser uma pessoa estudiosa e disciplinada. À Larissa Amaro, afetuosa irmã e brilhante tradutora, por ter revisado este trabalho e, principalmente, por ter sido a primeira pessoa a me apoiar na decisão de largar o curso de Ciência da Computação para cursar Ciência Política.

Agradeço aos amigos que tive a oportunidade de fazer na Universidade de Brasília, Fabíola Nader, Julia Viana, Dhyego Silva, Pedro Ribeiro, Guilherme Souto, Ronan Soares e Marcus Crispim, pelos bons momentos proporcionados em quase quatro anos de convivência. Agradeço também aos amigos de longa data, Gustavo Annes e Fernanda Feitosa, por me incentivarem nos momentos em que mais precisei. À família Werneck Cortes, por tudo que fizeram por mim no momento em que dava meus primeiros passos na Ciência Política e no Superior Tribunal de Justiça. À Fernanda Werneck e Déborah Alencar, pela compreensão e apoio que, em momentos diversos da minha vida, souberam dispensar a minha pessoa.

Agradeço à professora Flávia Biroli, do IPOL/UnB, pelos ensinamentos a respeito da história e da realidade social deste país, indispensáveis à formação de qualquer cientista político.

E, finalmente, agradeço ao meu estimado orientador Luis Felipe Miguel, figura ímpar no mundo da Ciência Política, pela motivante acidez com que tocou o processo de feitura desta monografia. 


\section{Resumo}

Dez anos após o retorno do regime democrático, os políticos brasileiros se viram pressionados a regularizar um fenômeno que se espalhava por todas as regiões do país: as rádios de baixa potência, conhecidas como rádios comunitárias. O objetivo deste trabalho é investigar um ponto específico da relação entra a política e a radiodifusão, qual seja, o potencial das rádios comunitárias para agirem como agentes da democracia e como instrumentos de transformação social, considerando as bases que foram estabelecidas pela Lei $\mathrm{n}^{\circ}$ 9.612/2008 e demais instrumentos jurídicos que regulam o sistema. Ao olharmos as normas definidas e, principalmente, os costumeiros entraves burocráticos que permeiam o Brasil, podemos ter um relance do pequeno espaço de manobra que foi concedido às rádios para alcançarem as finalidades estabelecidas por sua legislação. 


\section{Introdução}

A democracia está em voga. Em que lugar não se quer um pouco mais dela? No Brasil, nos Estados africanos - na universidade - seja lá para onde voltamos nossa atenção, o discurso que se escuta é de fortalecimento da democracia, quando não de sua imposição a força, situação por si só curiosa. Fato é que a partir da "terceira onda” de democratização ocorrida nos anos 70 e 80 a democracia tem sido defendida como um valor quase universal.

No Brasil, a democracia enquanto sistema político retornou com a Constituição de 1988. O jurista José Gomes Canotilho conta doze ocasiões em que expressões diretamente ligadas à democracia são encontradas em nossa Carta Constitucional, sem contar ainda os princípios que derivam ou são correlatos a estes, de modo que "o princípio democrático incorporou-se com força na Constituição em vigor, deixando em seu texto marcas profundas típicas de um princípio político constitucionalmente conformador”. (Canotilho apud Garcia, 1999, p. 122).

Se os princípios tendem a ser abstrações, "guias” para um desenvolvimento, deve-se observar que houve uma explícita transformação destes em regras de caráter democrático. Encontramos na Constituição todos os mecanismos de uma democracia representativa, inclusive o tão pleiteado voto direto, a partir daquele momento estendido de forma facultativa aos maiores de 16 e menores de 18 anos, e mesmo mecanismos pertencentes à democracia direta, como a possibilidade de um conjunto da população propor um projeto de lei (Kinzo, 2001, p. 8).

Dez anos após o retorno do regime democrático, os políticos brasileiros se viram pressionados a regularizar, por meio da Lei $\mathrm{n}^{\circ}$ 9.612/98, um fenômeno que se espalhava por todas as regiões do país: as rádios de baixa potência, conhecidas como rádios comunitárias. Dez anos após a promulgação da lei, já haviam sido abertas inscrições para a instalação de rádios comunitárias em 99,86\% dos municípios brasileiros, constando 3.202 entidades habilitadas a prestar o serviço, sendo que 2.379 destas desfrutam da licença definitiva (JB Online, 2008). No entanto, segundo a Abert (Associação Brasileira das Emissoras de Rádio e de Televisão), no final de 2006 existiam nada menos que 15.000 rádios operando de forma ilegal ou com autorização pendente de aprovação (Lobato, 2006). 
A expansão da radiodifusão comunitária levou a uma série de estudos quanto ao seu modo de funcionamento e a natureza de seu relacionamento com a esfera política. As controvérsias são muitas e começam mesmo no momento de caracterizar uma emissora. O mesmo objeto de estudo pode ser, para alguns, uma rádio comunitária; para outros, uma rádio pirata e, para terceiros, uma rádio livre. No entanto, um ponto compartilhado por todos os estudiosos é que existe uma relação direta entre o mundo político e os veículos comunitários, relação que não é exclusiva destes e que engloba todos os serviços de radiodifusão. Segundo Venício Artur de Lima e Cristiano Aguiar Lopes, “o vínculo entre radiodifusão e política é fenômeno fortemente arraigado na cultura e na prática política brasileira e perpassa os tempos de ditadura e os tempos de democracia” (2007, p. 8).

O objetivo deste trabalho é investigar um ponto específico dessa relação, qual seja, o potencial das rádios comunitárias para agirem como agentes da democracia e como instrumentos de transformação social, considerando as bases que foram estabelecidas pela Lei $n^{0}$ 9.612/2008 e demais instrumentos jurídicos que regulam o sistema. Ao olharmos as normas definidas e, principalmente, os costumeiros entraves burocráticos que permeiam o Brasil, podemos ter um relance do pequeno espaço de manobra que foi concedido às rádios para alcançarem as finalidades estabelecidas por sua legislação.

Para atingir o objetivo proposto, dividiu-se este trabalho em três capítulos. Antes de partir para uma análise focada propriamente nas rádios, o primeiro capítulo promove uma breve discussão sobre a tão fluida noção de democracia, caracterizada por muito mais do que as simples regras presentes em nossa Constituição. Pelo contrário, por meio das idéias do filósofo americano John Dewey, buscou-se apresentar uma noção de democracia que faça jus ao termo, que não se limite a enxergá-la como um sistema de governo, mas sim como um modo de vida; a democracia como uma idéia. É estabelecendo um referencial claro da noção de democracia que se torna possível avaliar se as rádios possuem ou não a capacidade de trabalhar como agentes democratizantes.

O segundo capítulo apresenta os resultados de pesquisa desenvolvida no $2^{\circ}$ semestre de 2007 e que teve como objetivo mapear o debate político relativo à radiodifusão comunitária por meio da análise dos discursos proferidos no Plenário da Câmara dos Deputados no período de 2003 a 2006. A pesquisa permitiu identificar uma fala razoavelmente homogênea entre os parlamentares, que enxergam nas rádios 
comunitárias uma capacidade intrínseca de promover transformações sociais, contribuindo também para o desenvolvimento da democracia.

Por fim, o terceiro capítulo apresenta o marco legal referente ao serviço de radiodifusão comunitária, destacando as principais leis, normas e portarias que regulam o setor. Após listar os objetivos e finalidades previstos, são destacados os entraves presentes na legislação brasileira, bem como uma relação dos principais projetos de lei que se encontram tramitando na Câmara dos Deputados, identificando-se, também, as temáticas recorrentes. 


\section{Capítulo I}

\section{A democracia como uma idéia}

O processo de investigação do potencial democrático das rádios comunitárias nos obriga primeiramente a discutir qual rumo a noção de democracia tem tomado. Indagar se as rádios possuem ou não capacidade para agir como agentes democratizantes pressupõe separar visões completamente distintas a respeito da democracia, destacando, ao fim, aquela que faça jus ao sentido do conceito, onde o poder de decisão esteja no maior grau possível sendo exercido pelos cidadãos, onde exista a menor limitação possível de sua participação e que não exclua em sua formulação a dimensão social.

Antes de apresentar a teoria que resgata as bases acima mencionadas, é impossível não tratar de forma breve a respeito da democracia concorrencial, corrente que há certo tempo domina as discussões, tendo se tornado a visão predominante a respeito da democracia, enfatizando a estabilidade, a descentralização burocrática e a disputa competitiva entre elites, ao mesmo tempo em que diminui o papel da participação direta da população no processo político (Whipple, 2005). Seu marco é o livro Capitalismo, Socialismo e Democracia, lançado em 1942 pelo austríaco Joseph Schumpeter, cujas idéias contribuíram para legitimar os regimes eleitorais do Ocidente como verdadeiros espaços democráticos e para minar os avanços dos que defendiam maior espaço para participação (Miguel, 2002).

Schumpeter inverte a lógica que, segundo ele, estaria presente na "democracia clássica”, apresentada em detalhes no capítulo XXI de seu livro. Se antes a escolha dos representantes era fator secundário, subjacente ao poder da população de tomar decisões políticas, em sua teoria democrática os posicionamentos e decisões por parte da população são considerados secundários em relação à eleição dos representantes. Sua definição de democracia é tão clara quanto vazia: “o método democrático é aquele acordo institucional para se chegar a decisões políticas em que os indivíduos adquirem o poder de decisão através de uma luta competitiva pelos votos da população” (Schumpeter, 1984, p. 336). Digo vazia porque é meramente procedimental, porque não possui em seu cerne questões como a igualdade entre os indivíduos e a tomada coletiva de decisões; pelo contrário, Schumpeter considera as pessoas egoístas e desinformadas, 
intrinsecamente incapazes de tratarem de assuntos coletivos e de avaliarem as conseqüências de seus atos (Miguel, 2002). O único princípio assegurado é o da liberdade formal, no sentido de que todos podem concorrer aos cargos em disputa.

Algumas das idéias de Schumpeter foram antecipadas por Hans Kelsen em sua obra Essência e o valor da democracia, de 1929, onde encontramos também uma visão procedimental, tendo como centro a idéia de que a democracia é um método para seleção de “chefes” (Brandão, 2006). Aqui, como em Schumpeter, a eleição se torna o elemento essencial da democracia, envolvendo a luta competitiva pelo poder em um ambiente onde está garantida a liberdade individual dos cidadãos. O que diferencia os autores é a intensidade na incorporação dos valores liberais, explícita em Kelsen e tímida em Schumpeter, onde existe uma distinção clara entre método democrático e liberalismo político, podendo o primeiro ocorrer onde o segundo está, em alguma dimensão, ausente (idem, p. 137).

Valendo-me da expressão de Luis Felipe Miguel, o que ocorre aqui é um "rebaixamento do ideal democrático”, onde a participação dos indivíduos é esvaziada a ponto de se resumir apenas ao ato de depositar seu voto em uma urna. Na teoria de Schumpeter, a soma de todos os votos nem mesmo expressa a vontade da maioria, tendo em vista que o autor considera que a massa de eleitores é sempre manipulada pela propaganda política ${ }^{1}$; segundo Schumpeter, “ao votar, o povo não decide nada, mas pensa que está decidindo - e, por isso, dispõe-se a obedecer aos governantes” (Miguel, 2002). Assim, enquanto a democracia assume um caráter legitimador da ordem vigente em cada realidade onde pode ser encontrada - ordem que tende a ser definida em outros planos da vida social - a teoria de Schumpeter ajuda a legitimar os regimes eleitorais como um todo, regimes que cada vez mais excluem a participação de forma direta por parte dos cidadãos.

Um contraponto direto à democracia concorrencial é a democracia participativa, que procura “incorporar na prática democrática novos e modernos instrumentos de controle e de participação no poder” (Carrion, 2001, p. 51). Trabalhada inicialmente por Rousseau, J. S. Mill e G. D. H. Cole, essa teoria democrática propõem que a participação dos indivíduos produz um maior controle da agenda política, dos processos de decisão e implementação, possuindo ainda um efeito educativo, fundamental para estimular e sustentar a participação, transformando as pessoas envolvidas por meio de

\footnotetext{
${ }^{1}$ Outro teórico que compartilha dessa visão é Robert Michels, cujas idéias são contrapostas à corrente da democracia participativa em Wolfe, 2008.
} 
um crescimento psicológico e do aumento de experiência prática para o envolvimento em questões políticas (Wolfe, 1985). Segundo Carole Pateman, “a participação desenvolve e promove as principais qualidades necessárias ao seu fim; quanto mais os indivíduos participam, se tornam cada vez mais capazes de realizar tal ação” (Pateman apud Wolfe, 1985, p. 371).

Para Botwinick e Bachrach (1983, p. 365), a verdadeira face da democracia participativa ainda não pôde ser vista devido à noção de "participação política" estabelecida pela doutrina liberal, exemplificada nas palavras de Sidney Verba e Norman Nie: “atividades desempenhadas por cidadãos comuns que visam, de certa forma, influenciar a seleção de funcionários do governo ou as ações por eles tomadas”. Assim, a participação das pessoas se resumiria em comunicar seus interesses particulares à elite dirigente. Essa noção de participação como mera promotora de interesses (econômicos e sociais) privados se tornou hegemônica, favorecida pela época de abundância de recursos em que vive o homem. Enquanto os indivíduos encontram oportunidades de crescimento em sua esfera privada, as tensões da sociedade são parcialmente absorvidas, existe relativo consenso e o próprio incentivo para ação política tende a ser pequeno. No entanto, em momentos de escassez, quando a esfera privada for incapaz de proporcionar a satisfação esperada pelos indivíduos, uma reorientação para a verdadeira democracia participativa pode ser a única alternativa para a permanência na sociedade de princípios da democracia liberal, evitando outras soluções para momentos de escassez, como coletivizações de caráter socialista ou fascista (Botwinick e Bachrach, 1983).

Mesmo que consideremos válida a definição liberal de participação citada anteriormente, fica difícil enxergar nela traços mínimos de democracia, tendo em vista que a própria participação ficaria restrita aqueles que possuem melhores meios para influenciar o governo e se fazer ouvir. Assim, Botwinick e Bachrach (1983) destacam a importância da criação de fóruns e de redes de participação dentro da sociedade, espaços de educação onde possa ocorrer uma transformação dos interesses pessoais e a redefinição das relações de poder, a fim de se garantir a permanência dos valores democráticos.

Norberto Bobbio pode também ser considerado um defensor da democracia participativa, no período em que pertencia ao Partido da Ação italiano, tendo sido influenciado por correntes tão distintas quanto o socialismo e o liberalismo, possuindo como pilares de seu pensamento a participação ativa da cidadania e o federalismo, 
enxergando como finalidade máxima da democracia a educação dos cidadãos para a liberdade (Brandão, 2006). Do liberalismo, tomou as idéias do escritor italiano Cattaneo, que defendia o federalismo como forma de descentralização política; do socialismo, a ampla participação política em todas as esferas da sociedade. Segundo Bobbio, a descentralização estatal, na medida em que promove a autonomia municipal, abre a possibilidade de encaminhar-se "na direção de uma genuína democracia, posto que esta multiplicidade de centros autônomos pressupõe e promove uma maior participação dos cidadãos na coisa pública” (Bobbio apud Brandão, 2006, p. 130). Nesse sentido temos também o jurista Eduardo Carrion, para o qual “o desenvolvimento da prática de uma democracia participativa, mesmo no contexto de uma democracia liberal, poderá revelar-se fator de educação política e de fortalecimento de uma cidadania mais ativa” (Carrion, 2001, p. 52).

Os teóricos da democracia participativa não excluem por completo a representação política, tendo em vista a incompatibilidade de tal supressão com o elevado número de cidadãos em cada Estado e a multiplicidade e complexidade de uma série de questões que permeiam o debate político, como a política monetária ou a política industrial (Dexheimer, 2006, p. 19). No entanto, se a adoção de procedimentos (como a regra da maioria) não é suficiente para definir uma democracia, também não se espera que toda decisão política seja tomada por meio de uma consulta popular. O que se busca é conciliar momentos de representação com momentos de participação direta, seja em âmbito nacional, seja na gerência dos assuntos pertinentes à cada localidade ${ }^{2}$.

Joel D. Wolfe (1985) propõe uma teoria revisada da democracia participativa tendo como objeto de estudo grandes partidos e organizações sindicais. Wolfe defende um modelo baseado no desenvolvimento de solidariedade coletiva dentro de pequenos grupos, voltados para relações sociais igualitárias e livres de exploração, pertencentes a uma base social que, por sua vez, daria origem a uma outra comunidade formada por conselhos de delegados. O autor segue o modelo de C. B. Macpherson de "um sistema piramidal na base e democracia delegativa à cada nível acima” (Wolfe, 1985).

A noção de solidariedade é trabalhada também por Jane Mansbridge (1983) em seu modelo intitulado "Unitary Democracy”, uma oposição direta à democracia concorrencial e sua visão inspirada nas idéias econômicas do laissez-faire, visão que concebe a sociedade como um mero agregado de interesses egoístas que, reunidos,

\footnotetext{
${ }^{2}$ Um apanhado dos autores que defendem a articulação entre as duas correntes democráticas pode ser encontrado em Vitullo, 2008.
} 
levariam automaticamente a um interesse comum. O modelo de Mansbridge apresenta uma nova proposta para as bases da democracia: igualdade de respeito contra igualdade na proteção de interesses; consenso contra regra de maioria; contato face-a-face contra voto secreto. Esse modelo dialoga diretamente com a corrente da democracia comunitária (Communitarian Democracy), que considera a democracia como um meio de se realizar o bem comum baseado na mobilização de valores morais compartilhados, a fim de alcançar um consenso tão forte que tenha um peso maior que os direitos individuais e o somatório do conjunto de interesses. Nesse sentido, o primeiro ambiente para a experiência democrática não é o governo ou o mercado, pelo contrário, são as comunidades, desde famílias e vizinhanças passando a municípios, cidades e nações (Gabardi, 2001).

As idéias da autora se tornam de fácil visualização quando aplicadas a grupos comunitários, onde se encontra presente um sentimento de amizade (e conseqüentemente de igualdade) fundamental para o desenvolvimento da democracia. Nesse ambiente, a similaridade dos interesses permite que as decisões sejam tomadas não pelo somatório dos votos - que tende, inclusive, a desagregar as pessoas e sufocar as minorias - mas por consenso, pela discussão direta entre os interessados, aumentando sua identificação com o outro e, conseqüentemente, com o grupo; identificação que, por sua vez, retro-alimenta a similaridade de interesses.

As correntes expostas até aqui trabalham a democracia, grosso modo, como um sistema de governo. Tratam do acesso a um conjunto de instituições e ao processo de tomada de decisões, seja pela eleição de representantes ou pela participação direta da população. Essas correntes não enquadram a democracia nas múltiplas dimensões que esta possui, tendo como resultado, em alguns casos, uma pequena lacuna e, em outros, a perda quase total do significado da palavra. Assim, torna-se necessário buscar uma teoria que restabeleça o conteúdo do conceito, que faça a distinção entre a democracia enquanto sistema e a democracia enquanto idéia. Thamy Pogrebinschi resume bem a questão:

A democracia, sua realização, transcende o Estado: ela encontra-se, simultaneamente, em todos os modos de associação humana dentro da comunidade, afetando-os reciprocamente. Para que a idéia de democracia seja realizada, em conseqüência, ela precisa produzir os efeitos sobre a família, a escola, a religião, o trabalho. Nesse sentido, a "democracia política" - isto é, a democracia como sistema de governo - com seus arranjos políticos e instituições governamentais consiste meramente em um mecanismo destinado a assegurar canais 
de operação para a "idéia" de democracia. (...) A democracia enquanto forma de governo pode a qualquer momento ser revista, modificada, sem que isso afete a idéia de democracia. Isso porque a “idéia” sempre encontrará uma maquinaria política mais adequada para, por meio dela, continuar funcionando (2004, p. 44).

A teoria que resolve essa equação foi desenvolvida por John Dewey. É a noção de democracia trabalhada pelo filósofo americano que deverá estar em mente a partir deste momento sempre que me referir ao "potencial democrático" da radiodifusão comunitária. Antes de tratarmos propriamente de suas idéias, precisamos destacar o principal ponto de discordância apresentado com a corrente procedimental da democracia. Dewey deixa claro em "The Ethics of Democracy" que reduzir a democracia ao princípio numérico da regra da maioria significa assumir que a sociedade é nada mais do que uma desorganizada massa de indivíduos isolados cujos objetivos são tão incompatíveis uns com os outros que a intenção ou opinião da maioria precisa ser descoberta de forma matemática; seria muito fora da realidade, para Dewey, acreditar que a vida social se dá sem nenhuma associação entre indivíduos que seja anterior às associações de caráter político (Honneth e Farrell, 1998). Como veremos posteriormente, o grande diferencial em seu modo de enxergar a democracia se encontra justamente em destacá-la do mundo político, ressaltando sua influência na vida social e no cotidiano dos indivíduos.

John Dewey é mais comumente reconhecido como um dos principais expoentes do pragmatismo, suas obras datando do final do século XIX e do início do século XX. Seus estudos tratam de uma série de temas como educação, psicologia, religião e teoria da democracia, esta última abordada por diversos caminhos ${ }^{3}$. Foge do escopo deste texto fazer uma revisão completa da obra do autor ligada à democracia. Vamos nos ater aqui a dois pequenos fragmentos de seu pensamento: a democracia como uma idéia, de forma central, e a noção de "reflective human agency" que, trabalhando elementos como conflito e participação, se mostra como instrumento para a superação de falhas de comunicação, outro ponto importante para o estudo da radiodifusão comunitária.

Pogrebinschi expõem de forma clara e sucinta o primeiro ponto em seu artigo “A democracia do homem comum: resgatando a teoria política de John Dewey”, afirmando que o filósofo não estava preocupado com as "práticas governamentais” - sufrágio, regra da maioria - maquinários que seriam a "manifestação política” da idéia de

\footnotetext{
${ }^{3}$ Análises do filósofo sobre educação, a influência da psicologia bem como a questão epistemológica da democracia podem ser encontradas em Metz (1969) e Kaufman-Osborn (1984).
} 
democracia, esta ligada aos meios pelos quais a população pode reconhecer a si mesmo de modo a definir e expressar seus próprios interesses. Tanto Pogrebinschi (2004) quanto Debra Morris (1999) destacam que, para Dewey, a "Grande Sociedade" conceito de Grahan Wallas que concebe as sociedades modernas como abstratas e impessoais, incapazes de promoverem o entendimento de seus membros por meio de contato pessoal - deveria ser convertida em "Grande Comunidade” por meio de uma reestruturação tendo como modelo comunidades locais que propiciam o contato pessoal, a fim de que efetivamente o instrumental democrático passe a servir como auxiliar na solução cooperativa de problemas.

O conceito deweyano de comunidade consiste antes “em uma concepção idealizada de vida comunal, isto é, em um certo modo de vida a ser perseguido como ideal ético ou moral. (...) A democracia para Dewey possui os mesmos pressupostos que a comunidade, quais sejam, a participação, a educação e a comunicação” (Pogrebinschi, 2004, p. 45). Segundo o próprio Dewey, “a pura consciência de uma vida comunal, com todas as suas implicações, constitui a idéia de democracia” (Dewey apud Pogrebinschi, 2004, p. 46). Ao trabalhar a noção de comunidade em seu conceito de democracia, fica explícita a aproximação de suas idéias com as de Jane Mansbridge e a corrente da democracia comunitária, expostas anteriormente. Participação e educação, pontos chaves da democracia participativa, também são destacados.

Como será mostrado posteriormente, as rádios comunitárias precisam necessariamente estar ligadas a uma associação comunitária legalmente constituída. Assim, um modo simples de averiguar se as rádios podem agir como agentes democratizantes é investigar se elas possuem os meios para promover a participação, a educação e a comunicação da população a que estão ligadas, se ajudam a aproximar o contato pessoal de seus membros. Aqui, mais uma vez, devemos ressaltar a amplitude da teoria de Dewey, que não enxerga a democracia como vinculada necessariamente à política. Sintetiza Pogrebinschi:

A política passa a ser apenas um dos lugares, um dos momentos, uma das formas que assume a democracia. [Por outro lado], é na comunidade que os indivíduos e os grupos podem comunicar-se, interagindo uns com os outros, compartilhando suas atividades e conseqüências. Diante disso, talvez possamos afirmar que, para Dewey, a democracia encontra-se mais no social que no político mesmo porque este último plano só deve vir à tona quando o público descobrir-se e isso somente pode acontecer por meio do social (2004, p. 46). 
Estando no social, a noção de democracia aqui trabalhada deve ser entendida como um modo de vida, que por sua vez irá refletir nas instituições que são moldadas a partir dos entendimentos firmados pelas pessoas. Escreve Dewey em Democracy is Radical que “(...) no pensamento e na ação que a democracia é um modo pessoal de vida individual; que ela significa a possessão e o uso contínuo de certas atitudes” (Dewey apud Pogrebinschi, 2004, p. 50); posteriormente, afirma: “Ao invés de pensar em nossas próprias disposições e hábitos como acomodados a certas instituições, nós temos que aprender a pensar nestas últimas como expressões, projeções e extensões das atitudes pessoais habitualmente dominantes” (idem, p. 50).

O fator participação é especialmente destacado por alguns autores. Segundo Honneth e Farrel, "é apenas a experiência de participar, por meio de uma contribuição individual em atividades específicas de um grupo, que pode conscientizar um indivíduo da importância da democracia” (1998, p. 776). O ato de participar em atividades cooperativas dentro da comunidade possui múltiplos efeitos, no sentido de que ajuda tanto a desenvolver as potencialidades dos indivíduos quanto a aumentar o sentimento de auto-realização, de direção de sua própria vida e da vida da comunidade; "na medida em que a idéia de democracia engloba essa noção de auto-realização, ou seja, de constituição e consolidação recíprocas da individualidade e da coletividade uma por meio da outra, estabelece-se uma espécie de autogoverno” (Pogrebinschi, 2004, p. 47).

No entanto, nem sempre é possível observar empiricamente esse espírito participativo. Como destacado no início deste capítulo, as pessoas tendem a buscar crescimento e resolução de problemas na esfera privada e não na pública. Dewey não responsabiliza os cidadãos pelo que chama de “o eclipse do público”, mas sim os hábitos e costumes que emergem do processo político como ele tipicamente se apresenta, ou seja, passivo-representativo ao contrário de participativo (Whipple, 2005). O que pode reverter esse quadro é a inteligência dos indivíduos, fator que possui papel importante para o filósofo, que chega a definir a democracia como "inteligência organizada” (Morris, 1999, p. 616). Segundo Dewey, a inteligência não é apenas moldada pelo contexto social em que se insere, pelos hábitos da sociedade, ela possui também a habilidade de usar o pensamento e a crítica para mudar esse mesmo contexto social de que se deriva, agindo de forma reflexiva (Whipple, 2005). Daí provém o supracitado termo reflective human agency, que poderia ser livremente traduzido como “agência humana reflexiva”, firmando a noção de que os indivíduos não são meros 
escravos de seus hábitos e costumes, mas agentes ativos capazes de refletir a respeito de suas experiências passadas a fim de melhor direcionar suas futuras ações.

A capacidade de inteligência discutida no parágrafo anterior é desenvolvida não apenas por meio da educação, mas também no exercício da cidadania por meio do debate a respeito dos problemas que envolvem determinada comunidade, debate que deve ocorrer em um ambiente onde impera o livre exercício da comunicação (Pogrebinschi, 2004). Nesse ambiente, a inteligência exercida por meio da agência humana reflexiva funciona como ferramenta para a superação do dissenso e resolução de conflitos. Segundo Dewey, “a democracia expõe abertamente os conflitos, de modo que as reivindicações especiais advindas deles podem ser vistas, avaliadas, discutidas e julgadas à luz de interesses mais inclusivos” (Dewey apud Morris, 1999, p. 616).

No entanto, o "livre exercício da comunicação” previamente citado muitas vezes não é encontrado, ocorrendo uma série de distorções que minam a capacidade de deliberação, participação e agência humana reflexiva por parte dos indivíduos. Mark Whipple (2005) destaca dois problemas estruturais diretamente responsáveis por essas distorções e pela centralização de informações e conhecimento: a concentração dos meios de comunicação nas mãos de alguns poucos conglomerados e a grande expansão dos direitos de propriedade intelectual. Segundo o autor, por diversas vezes se provou que comercialização da comunicação e a redução do número de proprietários levam a difusão de um número menor de idéias, de forma que a própria mídia comercial tende a estreitar a quantidade de vozes e perspectivas que representa. Por outro lado, o foco na mera diversidade de conteúdo deixa de lado o potencial participatório-democrático e de agência humana reflexiva presente nas modernas comunicações.

Whipple apresenta, então, o trabalho do professor da Universidade de Nova York Yochai Benker, segundo o qual a tecnologia hoje existente torna possível a descentralização das comunicações e a concretização da democracia, no sentido em que permite que pequenos grupos de indivíduos se tornem usuários, participantes ativos na produção de informação ligada a seu ambiente e a sua realidade social. O objetivo é aumentar a capacidade de crítica e de agência humana reflexiva por parte dos cidadãos, o que demanda uma mudança de foco do modelo tradicional de mídia ligado à representação, onde as pessoas são vistas como consumidoras de um determinado (e muitas vezes limitado) espectro de idéias, para um modelo participativo e democrático onde o espectro de idéias sede um pouco de espaço para se acentuar a capacidade de crítica e reflexividade dos indivíduos como criadores e produtores. Afirma Benkler: 
“identificar e sustentar espaços públicos e assegurar acesso às fontes de comunicação são focos mais importantes para uma política de informação preocupada com a democracia do que assegurar que existam oito e não apenas três redes de TV ou rádio, ou que nenhuma delas esteja sob o controle de um mesmo grupo” (Benkler apud Whipple, 2005, p. 176).

As idéias apresentadas referentes à participação, agência humana reflexiva e à necessidade de incentivar a mudança de papel dos cidadãos de consumidores para usuários, bem como a discussão prévia a respeito da democracia como uma idéia, mostram como a radiodifusão comunitária parece se inserir bem dentro da concepção de democracia formulada por John Dewey, concepção que leva em conta as diversas dimensões do conceito, fortalecendo novamente seu significado. Mesmo sem nenhuma investigação detalhada, seria intuitivo pensar que rádios que possuem como base associações comunitárias teriam a capacidade de incentivar a participação cooperativa dentro do ambiente em que se inserem, incentivar o exercício da cidadania e, principalmente, trabalhar pela superação das distorções de comunicação, não só promovendo debates a fim de trabalhar o inevitável dissenso, mas incentivando a agência humana reflexiva por meio de uma participação mais direta na produção de conteúdos.

Antes de investigarmos a fundo o espaço existente para a concretização desses objetivos, mostrarei no capítulo seguinte que essa visão intuitiva a respeito das rádios comunitárias encontra-se cristalizada no pensamento e na fala dos representantes legais do povo brasileiro, ao mesmo tempo em que encontra certo amparo em relatos presentes na grande mídia. Analisando os discursos proferidos no plenário da Câmara dos Deputados, fica clara a disposição dos parlamentares em acreditar que as rádios possuem plena capacidade de promover transformações sociais e de serem ativas promotoras da democracia. 


\section{Capítulo II}

\section{Análise do discurso parlamentar: o imaginário a respeito das rádios comunitárias}

Os dados apresentados a seguir são fruto de pesquisa desenvolvida no $2^{\circ}$ semestre de 2007 e que teve como objetivo mapear o debate político relativo à radiodifusão comunitária por meio da análise do discurso parlamentar e da eventual identificação de uma linha de pensamento que permearia o poder legislativo, representado aqui pelos Deputados Federais. A fim de identificar a recente discussão sobre o tema, buscou-se a princípio os discursos proferidos no Plenário da Câmara dos Deputados durante o período do primeiro governo do Presidente Lula (2003/2006), utilizando-se como critério de pesquisa as expressões "rádios comunitárias", "rádio comunitária”, “radiodifusão comunitária”, “comunicação comunitária”, “rádios livres” e "rádios piratas".

Chegou-se a iniciar uma segunda etapa, tendo como foco a análise dos discursos proferidos desde a promulgação da lei de radiodifusão comunitária, em 1998, até o último ano do segundo mandato do Presidente Fernando Henrique Cardoso, em 2002. No final de 2007, a pesquisa pelo termo “rádios comunitárias”, tendo como base os discursos proferidos no período supracitado, retornava 98 resultados. No entanto, atualmente, valendo-se da mesma chave de pesquisa, a ferramenta de busca do sítio da Câmara dos Deputados simplesmente não retorna nenhum resultado. Diversas comunicações já foram encaminhadas aos responsáveis, promessas de resolução foram recebidas, mas até 5/8/08 os dados continuavam foram do ar.

Em virtude das dificuldades descritas, optou-se por analisar aqui apenas os dados referentes ao período de 2003 a 2006, sendo analisados 196 discursos diferentes. Excluindo-se os discursos onde os termos ligados à temática aparecem de forma incidental, chegou-se ao total de 139 discursos ligados ao tema.

Tendo em vista o número superior de homens no parlamento, era de se esperar uma predominância masculina no número de discursos analisados. No entanto, o domínio masculino é absurdo, com 91,4\% do total, observando-se ainda que 2/3 dos poucos discursos femininos foram proferidos por parlamentares considerados de esquerda. Seguindo os procedimentos usuais na ciência política brasileira (Fernandes, 
1995; Rodrigues, 2002), foram considerados de esquerda o Psol, PDT, PSB, PT, PPS e PV; de centro, PMDB e PSDB; e de direita PTB, PL, PFL, PP, PSL, PSC e PRONA.

A proporção de $2 / 3$ citada anteriormente se mantém também quando consideramos a integralidade dos discursos proferidos, resultado já esperado visto que a temática em foco aborda em seu cerne associações comunitárias, grupos populares e minoritários, historicamente associados com a esquerda.

Tabela 1 - Distribuição dos discursos por espectro ideológico

\begin{tabular}{|c|c|c|}
\hline Partidos & Quatidade de discursos & $\mathbf{\%}$ \\
\hline Esquerda & 90 & 64,8 \\
\hline Centro & 17 & 12,2 \\
\hline Direita & 32 & 23,0 \\
\hline
\end{tabular}

Fonte: pesquisa “Radiodifusão Comunitária” na Câmara dos Deputados (2003-2006)

A distribuição dos discursos dentro das cinco regiões do Brasil é coerente com a distribuição das próprias rádios no território brasileiro, indicando um interesse por parte dos parlamentares proporcional à realidade encontrada em cada região. Em 2006, as regiões Nordeste e Sudeste possuíam o maior número de rádios comunitárias instaladas, 1.059 e 797, respectivamente, totalizando 68,6\% do total. Somando os discursos proferidos por parlamentares destas mesmas regiões, chegamos ao total de 63,3\%. A tabela abaixo mostra que a correlação se mantém nas demais regiões.

Tabela 2 - Distribuição dos discursos, das rádios e dos parlamentares por região

\begin{tabular}{|c|c|c|c|c|c|}
\hline Região & Discursos & $\mathbf{\%}$ & Rádios & $\mathbf{\%}$ & $\begin{array}{c}\text { \% de } \\
\text { Parlamentares } \\
\text { na Câmara }\end{array}$ \\
\hline Sul & 23 & 16,5 & 451 & 16,7 & 15,0 \\
\hline Sudeste & 28 & 20,1 & 797 & 29,5 & 34,9 \\
\hline Centro-Oeste & 15 & 10,8 & 211 & 7,8 & 8,00 \\
\hline Nordeste & 60 & 43,2 & 1.059 & 39,1 & 29,4 \\
\hline Norte & 13 & 9,4 & 186 & 6,9 & 12,7 \\
\hline TOTAL & 139 & 100 & 2704 & 100 & 100 \\
\hline
\end{tabular}

Fonte: pesquisa “Radiodifusão Comunitária” na Câmara dos Deputados (2003-2006) e IBGE 
É possível levantar hipóteses sobre os motivos pelos quais a região Nordeste possui tal predomínio nos dois parâmetros, apresentando também uma quantidade de discursos proferidos proporcionalmente superior a quantidade de parlamentares na Câmara. Primeiramente, e como será explicitado posteriormente, quase 1/4 dos discursos proferidos tratam de arbitrariedades cometidas contra as rádios comunitárias. A rarefeita presença do Estado em algumas localidades e os notórios e recorrentes casos de desrespeito às leis na região certamente culminam em uma quantidade maior de abusos, esta refletida na quantidade de discursos proferidos. Em outra dimensão, a precariedade de grande parte da região pode ter sido campo fértil tanto para o surgimento de rádios efetivamente voltadas para a vida comunitária, reconhecidas muitas vezes nos discursos como prestadoras de serviços sociais, como para o surgimento de rádios ditas comunitárias mas que na verdade funcionam à serviços de interesses particulares, buscando aumentar ou diminuir o prestígio político de figuras locais.

Os discursos analisados foram classificados conforme o Gráfico 1, a fim de se identificar as principais linhas do debate. Era permitida a indicação de mais de uma temática, tendo em vista que os parlamentares muitas vezes aproveitam o escasso tempo de tribuna para tratar de diversos aspectos ligados à mesma questão; por exemplo, um deputado que, ao apresentar um projeto de lei, relata antes o fechamento arbitrário de uma rádio comunitária em seu estado. 


\title{
Gráfico 1 - classificação dos discursos
}

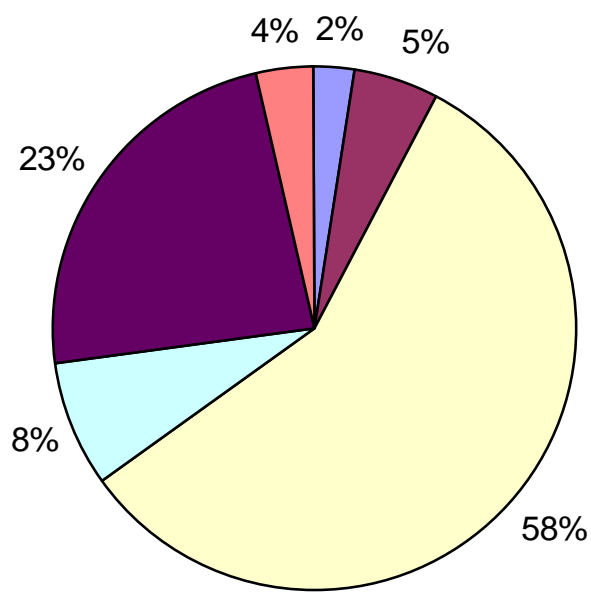

\author{
$\square$ discurso técnico / \\ apresentando resultados \\ de grupos de trabalho \\ $\square$ discurso encaminhando / \\ apresentando projeto de \\ lei \\ $\square$ discurso político com foco \\ em radiodifusão \\ comunitária \\ $\square$ discurso político com foco \\ em comunicação social \\ denúncia: divulgação de \\ abusos / arbitrariedades \\ por parte do governo \\ $\square$ denúncia: divulgação de \\ abusos por parte das \\ rádios
}

Foram classificados como "discurso político com foco em radiodifusão comunitária” aqueles que discutem questões estritamente ligadas ao tema, como o discurso proferido por Adão Pretto (PT/RS), em 10/10/2005, criticando a lentidão no processo de outorga e a criminalização das rádios comunitárias; ou o discurso proferido por Carlos Nader (PL/RJ), em 21/09/2004, que trata dos problemas causados pelas rádios ditas "piratas", traçando uma distinção entre essas e as rádios que operam de acordo com o que prevê a legislação, justificando a adoção de medidas legais contra as primeiras. Já os classificados como “discurso político com foco em comunicação social” tratam de forma subjacente questões ligadas à radiodifusão comunitária, estas inseridas em um debate mais amplo referente à comunicação no Brasil, como o discurso proferido por Sandro Mabel (PL/GO), em 07/04/2004, que, ao tratar da profissão de Jornalista, comenta sobre a concentração dos meios de mídia e da necessidade de se estimular a radiodifusão comunitária; ou o discurso proferido por Eduardo Sciarra (PFL/PR), em 22/09/2005, que, ao tratar sobre a radiodifusão e a profissão de radialista, ao final faz referência especial as rádios comunitárias, que define como "poderosos porta-vozes das comunidades em que atuam”. 
A questão dos abusos contra as rádios se mostrou a segunda maior no número de ocorrências, perdendo apenas para a ocorrência de discursos com foco em radiodifusão comunitária, estando a frente até mesmo dos discursos com foco em comunicação social. Indo ao encontro das hipóteses levantadas anteriormente, esses relatos de abusos foram proferidos prioritariamente por parlamentares da região Nordeste, com 19 ocorrências, praticamente o dobro da região Sul, que aparece em segundo lugar com 10 ocorrências, e quatro vezes maior que a região Sudeste, em terceiro lugar com 5 ocorrências. Os poucos relatos de abuso por parte das próprias rádios, que serão tratados aqui posteriormente, se concentram quase em sua totalidade (5 de 6 ocorrências) no Nordeste. Tendo em vista que abusos e arbitrariedades certamente depõem contra o governo, é interessante constatar que quem mais criticou o aparato governamental (nas figuras da Polícia Federal, ANATEL e Ministério das Comunicações) foram justamente os parlamentares de esquerda, grande parte deles pertencente à base aliada, responsáveis por $86,6 \%$ desse tipo de discurso. O Gráfico 2 mostra como os discursos proferidos por parlamentares de esquerda predominam independente da classificação, salvo quanto aos discursos apresentando projeto de lei, cuja direita possui pequena vantagem.

\section{Gráfico 2 - distribuição dos discursos tendo em vista à classificação e espectro ideológico}

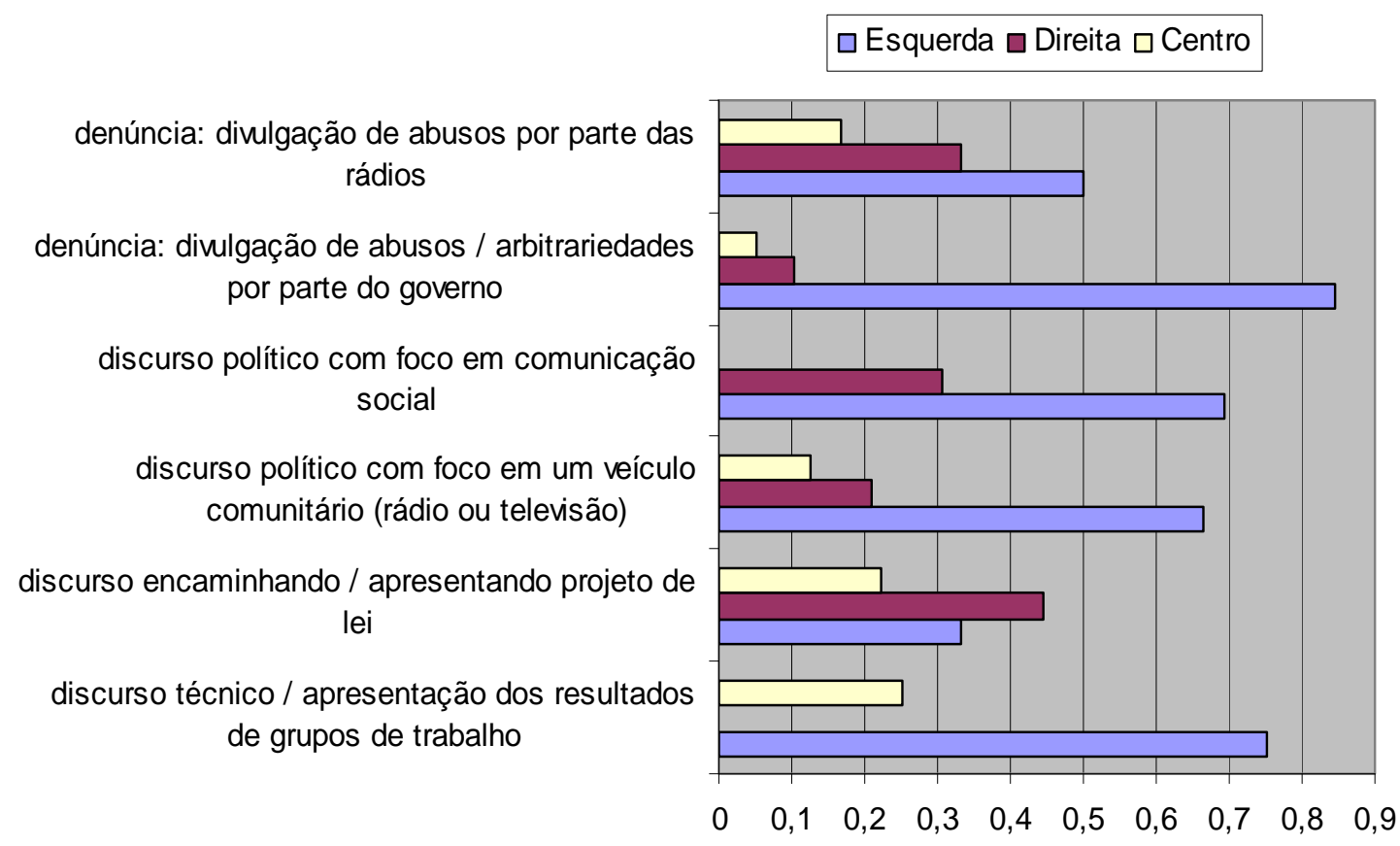


Os discursos com foco em radiodifusão comunitária e comunicação social foram posteriormente agrupados em subcategorias, a fim de se identificar posturas semelhantes e recorrentes na fala dos tão heterogêneos parlamentares. Destacaram-se, assim, oito diferentes tipos: discursos que abertamente exortavam as rádios comunitárias, atribuindo a elas importante papel social; discursos que repudiavam as rádios comunitárias, tratando dos problemas causados por elas; discursos que repudiavam especificamente rádios consideradas piratas e os crimes que estariam sendo praticados por essas emissoras; discursos que clamavam por uma maior regulamentação na área, cobrando um desenvolvimento maior das normas, bem como a outorga a novas emissoras; discursos que apresentavam sugestões de ações a serem implementadas, a fim de desenvolver a radiodifusão comunitária; discursos que exortavam o modo como o governo lida com as rádios, tratando principalmente do grande número de outorgas e da agilidade em se conceder licenças; discursos que repudiavam o modo de agir do governo, tratando do descaso existente com as rádios; e discursos onde o parlamentar apresentava suas realizações, muitas vezes auto-intitulando-se defensor das rádios. Novamente, era permitida a indicação de mais uma subcategoria por discurso.

Gráfico 3 - subcategoria de discurso político
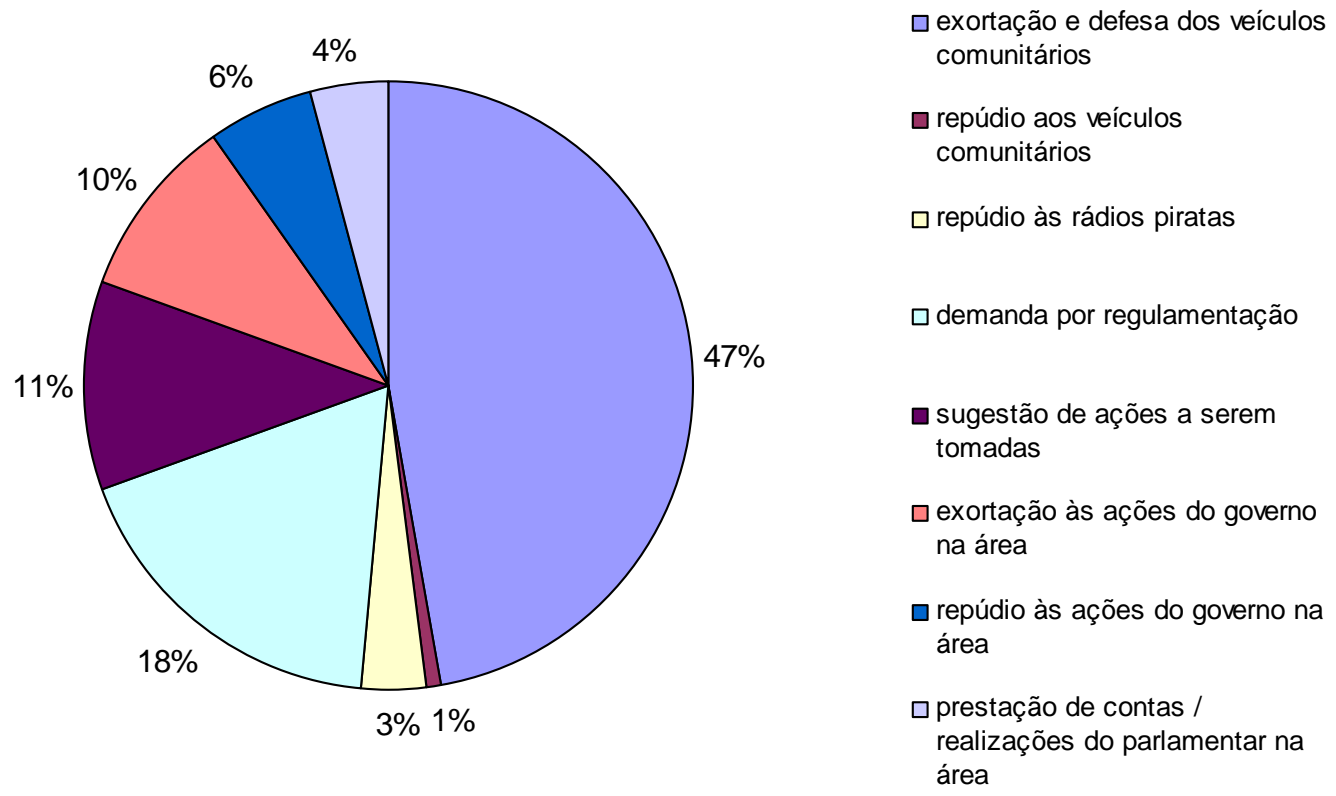

Nesse ponto começa a se desenhar a visão geral a respeito das rádios comunitárias: importantes veículos de comunicação, defendidos de forma expressa 
pelos parlamentares em quase 50\% dos discursos. Outra idéia recorrente é a necessidade de maior regulamentação na área, tanto no sentido de se aprimorar os instrumentos jurídicos, quanto no sentido de agilizar a regulamentação das diversas rádios que operam sem a devida autorização. Alguns parlamentares apresentaram sugestões de como melhorar a questão, formando a terceira maior incidência nas subcategorias.

Observando o Gráfico 3 é possível notar que a questão das rádios piratas, bastante destacada pela grande mídia, pouquíssimas vezes foi tocada pelos parlamentares. O foco se mantém mesmo na importância da radiodifusão comunitária e nos benefícios que esta pode trazer para a população, principalmente aquela de baixa renda ou que reside em pequenas localidades. Como mostra o Gráfico 4, a defesa das rádios é a idéia majoritária, independentemente da corrente ideológica.

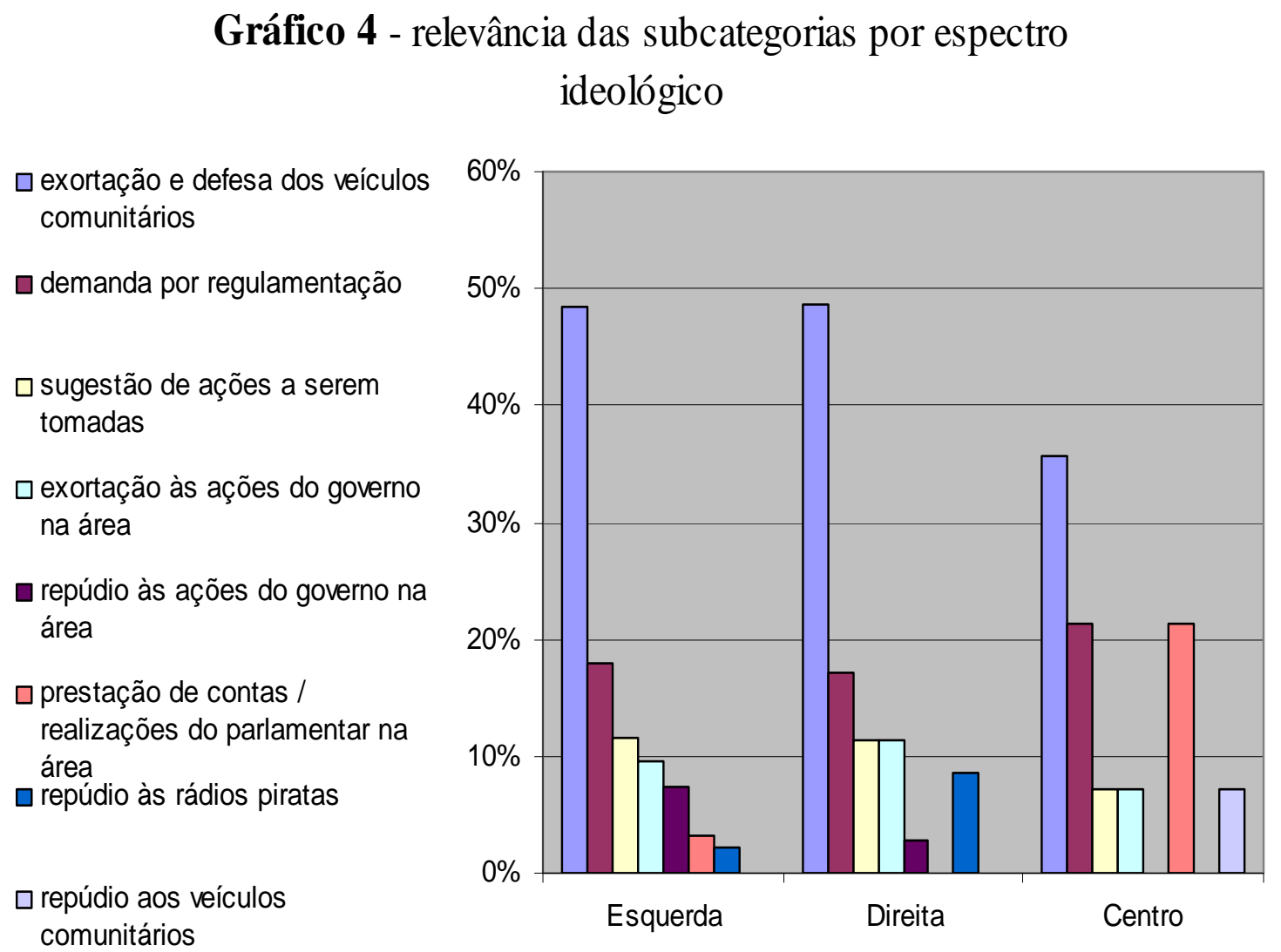

A leitura dos discursos, por fim, revelou uma série de argumentos que formam o núcleo da visão dos parlamentares a respeito das rádios comunitárias. Alguns deputados se limitavam a tocar em apenas um, mas outros em até mesmo quatro diferentes pontos da temática. 
Tabela 3 - Principais argumentos utilizados pelos deputados, número de ocorrências e a porcentagem de discursos em que estão presentes

\begin{tabular}{|l|l|l|}
\hline A Polícia Federal e/ou Anatel agem de forma arbitrária & 47 & $33,8 \%$ \\
\hline As rádios comunitárias são prestadoras de um serviço social & 32 & $23,0 \%$ \\
\hline As rádios comunitárias são promotoras da democracia e / ou cidadania & 25 & $18,0 \%$ \\
\hline Deve-se regulamentar as emissoras existentes & 17 & $12,2 \%$ \\
\hline A grande mídia e/ou emissoras comerciais procuram prejudicar as comunitárias & 17 & $12,2 \%$ \\
\hline O Ministério das Comunicações possui boa atuação na área & 12 & $8,6 \%$ \\
\hline Deve-se expandir a radiodifusão comunitária & 10 & $7,2 \%$ \\
\hline O governo Lula trata com descaso a questão & 8 & $5,8 \%$ \\
\hline As rádios comunitárias são instrumentos para a transformação social & 7 & $5,0 \%$ \\
\hline É necessário democratizar os meios de comunicação & 7 & $5,0 \%$ \\
\hline As outorgas de rádios comunitárias são condicionadas por interesses políticos & 5 & $3,6 \%$ \\
\hline Existem rádios comunitárias a serviço de interesses político-partidários & 5 & $3,6 \%$ \\
\hline É necessário desburocratizar o processo de outorga & 4 & $2,9 \%$ \\
\hline O Ministério das Comunicações é lento na aprovação das concessões & 4 & $2,9 \%$ \\
\hline O Governo FHC tratava com descaso a questão & 3 & $2,2 \%$ \\
\hline
\end{tabular}

Como mostrado anteriormente no Gráfico 1, 23\% dos discursos analisados tratam exclusivamente de denúncias de arbitrariedades cometidas contra as rádios comunitárias. No entanto, esse argumento aparece em 47 discursos diferentes, ou seja, em 33,8\% do total. Relatos de fechamento de rádios que não possuem autorização para funcionar expedida pela Anatel podem ser facilmente encontrados nos jornais: em 6/6/07, a Folha de S. Paulo relatou o fechamento de dez rádios em um único dia, sendo detidas oito pessoas, em operação conjunta envolvendo a Polícia Civil de São Paulo e servidores da Anatel (Freitas, 2007); em 23/10/07, a prefeitura de São Paulo derrubou uma torre que transmitia sinais de duas rádios na zona norte da cidade (Folha Online, 2007a); em 22/11/07, mais duas rádio foram fechadas em São Paulo (Folha Online, 2007b), e em 12/4/08 mais quatro foram fechadas em Osasco (Folha Online, 2008). Usou-se São Paulo como exemplo, mas os fechamentos se repetem de norte a sul do país. Só no Distrito Federal, 34 rádios foram fechadas em 2003 e 36 em 2004 (GOULART, Guilherme; BERNARDES, Adriana, 2005).

Independente das rádios fechadas serem prestadoras de serviços comunitários ou simplesmente estações servindo a interesses privados, o tom empregado nos discursos pelos parlamentares é o de abuso por parte dos agentes estatais: ações realizadas pela Polícia Federal e pela Anatel sem o devido mandado judicial ou, mesmo em casos determinados pela justiça, ações que são marcadas pela violência. O deputado Nazareno 
Fonteles, do PT do Piauí, relata em 31/8/05 o fechamento da “Utopia FM” em uma ação que levou à morte de uma funcionária da rádio. Vale citar que a referida rádio estava com seu pedido de regularização engavetado há sete anos.

Zé Geraldo (PT/PA) relata em 31/11/06 que a Polícia Federal estaria fechando rádios em processo de legalização no Ministério, tema que já havia sido tocado por Fátima Bezerra (PT/RN) em 13/11/03 ao solicitar uma medida provisória que permitisse às rádios comunitárias atuar com tranqüilidade até que a legislação definitiva seja aprovada, idéia defendida no mesmo ano por Ary Vanazzi (PT/RS). Já o deputado Benedito de Lira (PPB/AL), em 21/5/03, isentou de culpa a Polícia Federal nas apreensões realizadas, argumentando que ela estaria apenas cumprindo mandado judicial suscitado pela ANATEL, verdadeira culpada.

Independente do agente causador, os discursos encontram paralelo com o noticiado pela mídia: no dia 4/10/05 a polícia federal invadiu e fechou a "Rádio Pop Goiaba”, um projeto de extensão do Curso de Antropologia da Universidade Federal Fluminense (UFF). "Fizemos os primeiros testes em julho de 2003 e a rádio funcionou até abril de 2004, quando tivemos que mudar de endereço. Depois entramos com toda a documentação necessária para regulamentar a rádio e em fevereiro deste ano conseguimos um registro provisório, que teria um prazo de seis meses para ser aprovado pelo Congresso. Com a crise política, essa aprovação não aconteceu, mas, de qualquer forma, o registro prévio é uma garantia de que a rádio não é ilegal. Nada justifica a invasão”, relata um dos responsáveis pela rádio (Gobbi, 2005).

O quadro descrito é muito diferente do que era esperado meses antes da posse do presidente Lula, em 2003. Segundo Laura Mattos (2003), "Na internet, logo após as eleições, os comentários em blogs de discussão de rádio eram recheados de inocência, para dizer o mínimo. O clima era de 'agora vai’. Uma das razões, claro, é a ligação histórica entre o PT e os primeiros movimentos de defesa das rádios comunitárias do país”. O resultado não poderia ser mais distinto: levantamento realizado pela Anatel a pedido do jornal Folha de S. Paulo mostra que, no primeiro ano da gestão do PT, o número de emissoras fechadas pela Anatel cresceu em cerca de 17\%. Foram 2.759, contra 2.360 em 2002 (Mattos, 2004).

Em número de ocorrências, os argumentos de que as rádios comunitárias são prestadoras de um serviço social e promotoras da democracia e / ou cidadania aparecem logo em seguida, respectivamente em segundo e terceiro lugares. Como será mostrado posteriormente, a visão das rádios enquanto prestadoras de um serviço social é a que 
possui maior incidência nos discursos dos partidos de Direita e de Centro, não sendo possível afirmar que esse é um argumento exclusivo da Esquerda, historicamente ligada à radiodifusão comunitária.

Segundo Zé Geraldo (PT/PA), “uma rádio comunitária é a conseqüência política da democratização da sociedade que traça estratégias de articulação e cria uma 'base social instalada', com inúmeras entidades que necessitam de meios comunicativos para interagir com a sociedade”. Posteriormente, afirma que “as rádios comunitárias acompanham a dinâmica da realidade social, a partir dos fatos relevantes, da implicância de suas causas, das suas conseqüências, de conjecturas e disponibiliza essas informações para toda a sociedade, ensejando a formação para atuação em problemas e soluções”; segundo Cláudio Cajado (PFL/BA), “a rádio comunitária poderia ser denominada de rádio do cidadão, pois a democratização dos meios de comunicação com o acesso às rádios comunitárias é um grande patrimônio do cidadão”; já Thelma de Oliveira (PSDB/MT) reconhece as rádios comunitárias como instrumentos "ligados à luta em favor da sociedade democrática, do pluralismo e da diversidade cultural, da ética e do amplo direito de comunicação”.

Diversos são também os exemplos citados pelos parlamentares para embasar seus discursos, tanto para defender os argumentos supracitados, como para provar que as rádios comunitárias são importantes instrumentos para a transformação social. Fernando Ferro (PT/PE), um dos principais defensores das rádios, expôs em 20/12/06 o êxito do programa de radiodifusão comunitária Prosa Rural, lançado pela EMBRAPA Informação Tecnológica. O programa é desenvolvido pela própria EMBRAPA e distribuído gratuitamente às rádios, tendo como objetivo levar ao público informações sobre temas ligados ao desenvolvimento agrário e rural que tenham alguma aplicação no dia-a-dia do pequeno produtor, de forma prática, clara e acessível. Adão Pretto (PT/RS) exaltou em 10/10/2005 a comemoração do aniversário de 2 anos de funcionamento da rádio comunitária da Associação do Movimento de Desenvolvimento Social e Radiocomunicação da cidade de São Pedro do Butiá, localizada na região das Missões do Rio Grande do Sul. Segundo o parlamentar, "essa rádio comunitária foi criada principalmente com a intenção de unir a comunidade, e trouxe consigo um processo muito grande de valorização da cultura, bem como de desenvolvimento do comércio local”.

Assim como no caso do fechamento das rádios, não é difícil encontrar na mídia referências a emissoras que se enquadram na visão defendida pelos parlamentares. Em 
20/12/05, a Folha de S. Paulo relatou um programa diário veiculado em rádios comunitárias e produzido por garis em Manaus, Amazonas. Com três minutos de duração, o programa é apresentado pelo gari Allan da Silva Nascimento, onde ele e mais três colegas "dão dicas de limpeza pública, de como separar o lixo seletivo, como limpar os quintais para não proliferar os mosquitos da dengue e da malária, além de realizar campanhas, como por exemplo, para proteção dos igarapés e matas que cercam Manaus” (Brasil, 2005). O JB Online em 3/6/05 noticiou que a Agência Nacional de Vigilância Sanitária (Anvisa) e o Procon de Pernambuco haviam renovado parceira com a Associação de Rádios Populares de Pernambuco, com o objetivo de se valer de 170 rádios para "fazer uma ampla divulgação sobre o uso de medicamentos e sobre os direitos dos cidadãos em relação ao consumo desses produtos”. Já o Correio Brasiliense, em 1/10/02, divulgava que a Gerência de DST/Aids da Secretaria de Saúde iria promover um curso gratuito para locutores, com o objetivo de treiná-los para dar orientações sobre as doenças sexualmente transmissíveis de forma correta (Correio Brasiliense, 2002).

A par do quadro positivo descrito até aqui, dois entraves ao bom funcionamento das rádios são destacados pelos parlamentares. Um deles é a existência de grandes conglomerados midiáticos, que de forma direta ou indireta acabam por prejudicar a radiodifusão comunitária. Segundo Nazareno Fonteles (PT/PI), a concentração dos meios de imprensa, que em várias ocasiões se encontram submetidos ao poderio de pequenos grupos, tende a prejudicar as rádios comunitárias, “que são privadas de sua capacidade de atingir em maior grau as comunidades onde funcionam, bem como de promover uma comunicação mais livre e independente”; nesse mesmo sentido temos o Deputado Dr. Rosinha, segundo o qual “cada vez mais há maior número de meios de comunicação pertencendo a menor número de pessoas, e a informação vai-se tornando mais distorcida, sendo objeto de manipulação por alguns setores que privatizaram de vez a comunicação relativa ao rádio e à tevê” (Câmara, 2005). Cecilta Pinheiro (PFL/MT) condenou a iniciativa da TV Globo de oferecer alguns de seus programas para serem retransmitidos pelas comunitárias: "Para nossa surpresa, justamente as grandes redes, que tanto têm combatido a legalização das rádios comunitárias, agora querem se servir delas para tirar proveito próprio”. Mais contundente em sua crítica, o Deputado Adão Pretto chegou mesmo a afirmar que a Anatel e a Polícia Federal estariam fechando rádios comunitárias “a mando das rádios comerciais”. 
O outro entrave destacado é que a concessão de licenças para o funcionamento das rádios comunitárias estaria sujeita a pressões externas, existindo preferência para rádios que fossem apadrinhadas por determinados políticos, argumento presente, entre outros, em discursos proferidos, em 2003, de Zé Geraldo (PT/PA) e Francisca Trindade (PT/PI). Cristiano Aguiar Lopes, um dos autores da pesquisa "Rádios Comunitárias: Coronelismo Eletrônico de Novo Tipo”, afirma que se pode influenciar não só a aprovação de um pedido de concessão, mas também a velocidade de tramitação do processo, que pode variar de 20 dias até cerca de cinco anos (JB Online, 2007b). A um ano das eleições de 2002, o então Ministros das Comunicações, Pimenta da Veiga (PSDB), liberou 138 autorizações para funcionamento de rádios, sendo que 94 saíram apenas no dia 2 de outubro. Dezenove autorizações foram para municípios de Minas Gerais, onde Veiga pretendia se lançar candidato ao governo. Dom Silvério, o prefeito tucano Renato Trindade Teixeira, intercedeu junto ao ministro para obter autorização para a rádio administrada pela Associação de Radiodifusão Comunitária da Cidade de Dom Silvério: "Pedi sim", afirma ele (Gramacho, 2001).

Já a Deputada Luciana Genro (PSOL/RS) destacou, em junho de 2006, um caso conexo, em que Rádio São Vicente FM, na cidade de São Vicente do Sul, foi fechada por noticiar caso de corrupção envolvendo o Prefeito da cidade, o qual passou a ser investigado pelas autoridades locais (Câmara 2006). Noticia posteriormente publicada pelo jornal Zero Hora confirma que o prefeito foi efetivamente cassado (Zero Hora, 2006).

Por fim, e como mostra a Tabela 3, foram detectados 54 argumentos que não se enquadravam dentro dos principais padrões estabelecidos. Diversas foram as temáticas encontradas: parlamentares buscando crédito por terem agilizado processos de regularização junto ao Ministério das Comunicações e por terem inaugurado determinada rádio, parlamentares pedindo agilidade nas regularizações, descrição de novos projetos de lei a serem apresentados (incluindo do Deputado Carlos Nader, do PL do Rio de Janeiro, que previa pena de prisão para quem investisse ou financiasse rádios piratas), um comunicado de que a Polícia Federal de São Paulo deixaria de reprimir as rádios comunitárias, pedidos de anistia aos diretores das rádios fechadas e devolução de equipamentos, críticas à gestão do Presidente Fernando Henrique Cardoso, responsabilizada pelo acúmulo de processos de regularização, até mesmo mais de um caso de rádios proibidas de transmitir as sessões semanais de sua Câmara Municipal. 
O Gráfico 5 mostra a distribuição dos principais argumentos citados e sua relevância para os partidos de Esquerda, Centro e Direita.

Gráfico 5 - relevância dos argumentos por espectro ideológico
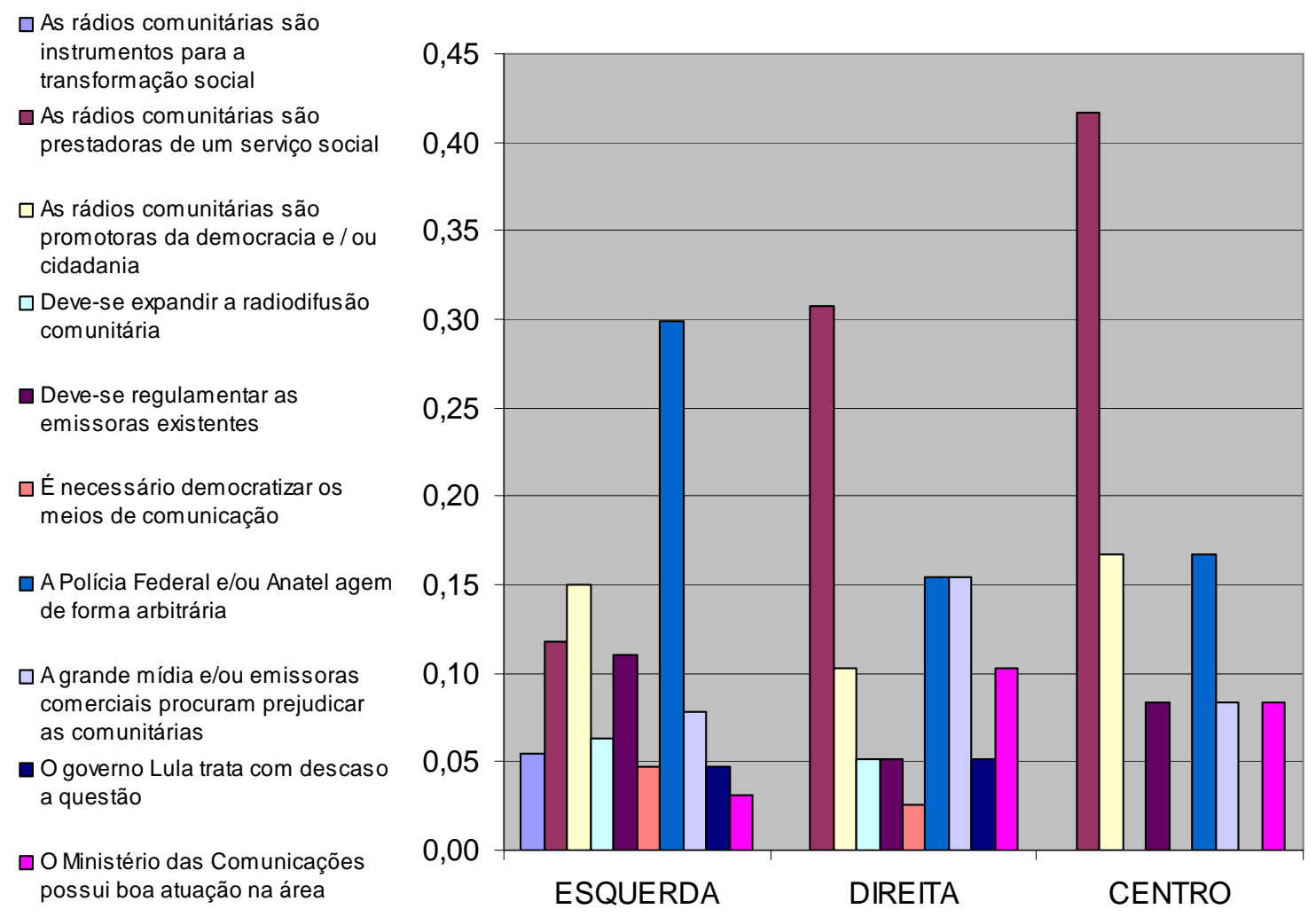

Os dados apresentados revelam que os parlamentares desenham um quadro relativamente homogêneo a respeito das rádios comunitárias: agentes democratizantes, com capacidade para gerar transformações sociais, mas fortemente perseguidos por instrumentos do Estado (Anatel e Polícia Federal). Os exemplos encontrados tanto nos discursos quanto na mídia reforçam a identificação das comunitárias com as idéias de John Dewey apresentadas no Capítulo I, no sentido de que a população encontra modos de expressar suas necessidades, deixam de ser consumidores e passam a condição de usuários, promovendo a participação e a educação por meio da comunicação.

A otimista visão dos parlamentares, bem como o sucesso de algumas ações implementadas por rádios comunitárias, no entanto, não podem nos levar a conclusão de que o sistema de regulamentação implementado no Brasil é o adequado a nossa realidade. As regras atualmente em vigor incentivam a radiodifusão comunitária, estabelecem as bases para um funcionamento que efetivamente promova transformações 
sociais e a democracia, ou os exemplos de sucesso que encontramos são verdadeiros milagres frente às normas em vigor? Quais alterações tem sido buscadas? Em qual direção se tem construído os novos projetos? Essas e outras questões serão analisadas no capítulo seguinte. 


\section{Capítulo III}

\section{A legislação vigente e as perspectivas de avanço}

O serviço de radiodifusão comunitária no Brasil encontra-se regulado por um número relativamente pequeno de normas. Seu principal marco legal é a Lei ${ }^{\circ}$ 9.612/98 (Anexo A) que, por sua vez, foi complementada ou modificada por outros instrumentos jurídicos. Destacamos neste trabalho os mais relevantes: o Decreto $\mathrm{n}^{\circ} 2.615$ (Anexo B), de 3 de junho de 1998, que regulamentou a lei 9.612/98, aprovando o Regulamento do Serviço de Radiodifusão Comunitária; a Norma Complementar n 2/1998 (Anexo C), aprovada pela portaria $\mathrm{n}^{\circ} 191$, de 6 de agosto de 1998; e a Norma Complementar $\mathrm{n}^{\circ}$ 1/2004 (Anexo D) que, mais uma vez, complementa as disposições estabelecidas pela Lei n. ${ }^{\circ}$ 9.612/98.

Existem vários enfoques possíveis no estudo da legislação vigente. Foge ao escopo desta análise verificar se existe conflito entre a Lei $n^{0}$ 9.612/98 e dispositivos superiores, se esta é inconstitucional ou se fere princípios básicos da liberdade de expressão ou do direito à informação ${ }^{4}$. O que se procura investigar é se o modo como o serviço foi implementado no Brasil estabelece efetivamente as bases para o desenvolvimento de rádios comunitárias que sirvam a uma comunidade, que tenham a capacidade de promover a participação, a educação e a livre comunicação, bem como a aproximação entre seus membros, funcionando as rádios como efetivos agentes democratizantes.

Essas características, por sinal, vão ao encontro do Art. $3^{\circ}$ da Lei n ${ }^{\circ}$ 9.612/98, que estabelece como finalidade do Serviço de Radiodifusão Comunitária: I) dar oportunidade à difusão de idéias, elementos de cultura, tradições e hábitos sociais da comunidade; II) oferecer mecanismos à formação e integração da comunidade, estimulando o lazer, a cultura e o convívio social; III) prestar serviços de utilidade pública, integrando-se aos serviços de defesa civil, sempre que necessário; IV) contribuir para o aperfeiçoamento profissional nas áreas de atuação dos jornalistas e radialistas, de conformidade com a legislação profissional vigente; V) permitir a capacitação dos cidadãos no exercício do direito de expressão da forma mais acessível possível.

\footnotetext{
${ }^{4}$ Para estas e outras abordagens centradas no Direito, vide Silveira (2001)
} 
O Art. $4^{\circ}$ reforça a questão da integração da comunidade e da educação de seus membros, nos incisos I, II e III, determinando como princípios a serem seguidos pelas rádios “a preferência a finalidades educativas, artísticas, culturais e informativas em benefício do desenvolvimento geral da comunidade; a promoção das atividades artísticas e jornalísticas na comunidade e da integração dos membros da comunidade atendida; e o respeito aos valores éticos e sociais da pessoa e da família, favorecendo a integração dos membros da comunidade atendida”. Os parágrafos 2 e 3 do inciso IV deste mesmo artigo tratam da livre comunicação, estabelecendo, ainda, que "as programações opinativa e informativa observarão os princípios da pluralidade de opinião", e que "qualquer cidadão da comunidade beneficiada terá direito a emitir opiniões sobre quaisquer assuntos abordados na programação da emissora”. As rádios assegurarão também, de acordo com o Art. 15º "espaço para divulgação de planos e realizações de entidades ligadas, por suas finalidades, ao desenvolvimento da comunidade".

Buscou-se coibir a ingerência externa nos assuntos da comunidade por meio do Art. $11^{\circ}$, que estabelece que a entidade detentora de autorização para operar a rádio "não poderá estabelecer ou manter vínculos que a subordinem ou a sujeitem à gerência, à administração, ao domínio, ao comando ou à orientação de qualquer outra entidade, mediante compromissos ou relações financeiras, religiosas, familiares, políticopartidárias ou comerciais”. Como será discutido posteriormente, nem sempre essa norma é respeitada.

Apresentadas as finalidades que a lei estabelece, estas em clara sintonia com a noção de democracia desenvolvida no Capítulo I, cabe agora retornar ao Art. $1^{\circ}$ da Lei 9.612/98, responsável pela definição básica das rádios. Segundo este artigo, “denominase Serviço de Radiodifusão Comunitária a radiodifusão sonora, em freqüência modulada, operada em baixa potência e cobertura restrita, outorgada a fundações e associações comunitárias, sem fins lucrativos, com sede na localidade de prestação do serviço”. O $\S 1^{\circ}$ define como baixa potência o sinal limitado “a um máximo de 25 watts ERP e altura do sistema irradiante não superior a trinta metros”, bem como cobertura restrita aquela "destinada ao atendimento de determinada comunidade de um bairro e/ou vila”. Aqui, em seu Art. $1^{\circ}$, começam os entraves para a realização das finalidades supramencionadas.

Segundo técnicos da Anatel, em condições ideais - sem barreiras, como construções altas, por exemplo -, o sinal de um transmissor de 25 watts ERP poderia ser 
ouvido em torno de dez quilômetros (Igreja, 2004). No entanto, o relevo específico de cada região influencia sobremaneira o modo de dispersão das ondas. A legislação não prevê que se adeque cada realidade a uma potência diferente, limitando-se em estabelecer um teto. Indo além, no Art. $6^{\circ}$ do Decreto $n^{\circ}$ 2.615/98, estabelece que "a cobertura restrita de uma emissora do RadCom é a área limitada por um raio igual ou inferior a mil metros a partir da antena transmissora, destinada ao atendimento de determinada comunidade de um bairro, uma vila ou uma localidade de pequeno porte”. Se a Universidade de Brasília fosse tomada como um bairro, uma rádio comunitária operando legalmente seria incapaz de cobrir toda sua amplitude. De que adianta, então, montar todo um aparato, vencer uma extensa burocracia, se não é possível atingir todos os membros de uma comunidade?

Destaco, novamente, que a solução não seria simplesmente dobrar a potência ou expandir área de cobertura. A lei deveria ser flexível a ponto de contemplar diversas realidades, estudando caso a caso qual a potência ideal para contemplar a comunidade que requer a instalação do serviço de radiodifusão. A Norma Complementar no 1/2004 já estabelece no item 12 (“Da Apresentação do Projeto Técnico”) uma série de estudos que as comunidades devem apresentar para a instalação das rádios, de modo que caberia ao governo apenas analisar a documentação e, se for o caso, encomendar estudo complementar para melhor adequar a potencia do transmissor à região onde a comunidade se encontra. Fato é que não há embasamento técnico para o limite estabelecido de 25 watts ERP.

Ainda em relação à transmissão, a frágil realidade das comunitárias é expressa no Art. $22^{\circ}$ da Lei 9.612/98: “As emissoras do Serviço de Radiodifusão Comunitária operarão sem direito a proteção contra eventuais interferências causadas por emissoras de quaisquer Serviços de Telecomunicações e Radiodifusão regularmente instaladas”. Por outro lado, o Decreto $n^{\circ}$ 2.615/98 estabelece em seus Arts. $26^{\circ}$ e $27^{\circ}$ a interrupção do serviço de radiodifusão comunitária caso esse apresente interferência indesejável ou prejudicial nos demais serviços regulares de Telecomunicações e Radiodifusão. Ou seja, ainda que opere de forma legal, dentro do canal 200 (87,8 a 88,0 MHz) ou de canal alternativo designado, reservado exclusivamente para o serviço de radiodifusão comunitária, não existe garantia de que todos os recursos empenhados para a instalação da rádio não terão sido em vão. Indo além, a legislação vigente não estabelece foro para a resolução de conflitos, nem indica a quem as rádios podem recorrer caso se sintam lesadas. 
Outro entrave para se atingir as finalidades listadas na Lei $n^{0}$ 9.612/98 é a burocracia envolvida no processo de outorga. À parte da quantidade de documentos e estudos técnicos que devem ser entregues, o grande problema é que o poder para emitir as licenças de funcionamento se encontra centralizado no Executivo e Legislativo Federal, na figura do Ministério das Comunicações e da Câmara dos Deputados, respectivamente. O Decreto $n^{0} 2.615 / 98$ estabelece que os interessados em executar 0 serviço de RadCom deverão apresentar requerimento ao Ministério das Comunicações, ficando este requerimento sobrestado quando já existir, em análise no Ministério, pedido de autorização na mesma área de interesse. A tramitação dos requerimentos, segundo a Norma Complementar $n^{0} 1 / 2004$, deve obedecer à ordem cronológica de publicação dos Avisos de Habilitação - o que não ocorre em todas as ocasiões, conforme será oportunamente discutido.

Aprovado o requerimento, a autorização para funcionamento é outorgada por meio de portaria do Ministério das Comunicações, que produzirá efeitos legais somente após deliberação do Congresso Nacional, conforme disposto o $\S 3^{\circ}$ do Art. $223^{\circ}$ da Constituição Federal. No entanto, conforme estipulado pela Medida Provisória ${ }^{0}$ 2.14333/2001, sem a apreciação do Congresso em até noventa dias, o Ministério das Comunicações expedirá autorização de operação, em caráter provisório. Em abril de 2007, segundo o Ministro das Comunicações, quatro mil pedidos de habilitação aguardavam análise do Governo Federal (JB Online, 2007a); segundo Joaquim Carlos Carvalho, coordenador jurídico da Associação Brasileira de Radiodifusão Comunitária (Abraço), o tempo final para tramitação de um processo gira em torno de quatro anos e meio, em média (JB Online, 2007c). Vale ressaltar que, salvo o prazo de noventa dias citado acima, nenhuma norma referente à radiodifusão comunitária estabelece prazos para a ação do Estado, ao passo que a todo o momento, em diversos dispositivos, são elencados uma série de prazos a serem cumpridos pelas associações que pleiteiam o serviço de RadCom.

A centralização torna moroso o processo de outorga, tendo em vista que um único órgão, o Ministério das Comunicações, fica encarregado de um gigantesco volume de pedidos, a serem analisados por um número restrito de técnicos. Algo semelhante ocorre no Congresso Nacional, que além das tradicionais funções de representar, fiscalizar e legislar encontra-se, no Brasil, inflado com as mais diversas incumbências. A explicação legal para essa centralização encontra-se no Art. $21^{\circ}$ da Constituição, XII, “a”, segundo o qual “Compete à União explorar, diretamente ou 
mediante autorização, concessão ou permissão, os serviços de radiodifusão sonora, e de sons e imagens", bem como o já citado Art. $223^{\circ}$, segundo o qual "compete ao Poder Executivo outorgar e renovar concessão, permissão e autorização para o serviço de radiodifusão sonora e de sons e imagens, observado o princípio da complementaridade dos sistemas privado, público e estatal”.

No entanto, conforme bem nota o Juiz Federal Paulo Fernando Silveira (2001), a Constituição estabelece a competência da União para autorizar o serviço de radiodifusão apenas nos casos onde este envolve interesse nacional ou abrange mais de um Estadomembro, como no caso das rádios comercias e canais de televisão, todas de grande potência e enorme alcance. Deve-se levar em conta o preceito federalista, que estabelece o âmbito de atuação da União, citado anteriormente, o dos Estados-membros, constituído dos assuntos regionais, e o dos Municípios, que possuem o poder de legislar, com exclusividade e privativamente, sobre o interesse local, quando este for predominante. O mesmo se aplica à aprovação do Congresso Nacional, que somente é necessária ao se tratar de redes nacionais de televisão, de empresas telefônicas e de rádios comerciais.

Assim, não existe explicação para os dispositivos supracitados serem aplicados à questão da radiodifusão comunitária porque tal assunto é meramente local. Segundo Silveira (2001), “basta ler a Lei n 9.612/98 para se ter a inabalável convicção de que nenhum interesse nacional ou que supere o de um Estado-membro esteja em disputa. Ante ao argumento de que a União precisa proteger a aviação civil - e realmente tem esse interesse - deve exercer sua competência legislativa por meio da edição de normas gerais e não, como está acontecendo, pela pura e simples usurpação da competência municipal”.

A prova de que este entendimento ecoa pelo país é que, em 23/06/2005, o então prefeito de São Paulo José Serra sancionou a Lei $\mathrm{n}^{\circ}$ 14.013, fruto de projeto aprovado em maio pela Câmara Municipal de autoria dos vereadores Carlos Neder (PT) e Ricardo Montoro (PSDB), disciplinando a exploração do serviço de radiodifusão comunitária no âmbito do município. Fora o fato do poder para concessão de outorgas passar a ser do município, a principal alteração em relação à lei federal é a possibilidade das rádios captarem recursos na forma de apoio cultural de estabelecimentos situados fora da área da comunidade ${ }^{5}$.

\footnotetext{
${ }^{5}$ Em 2006, por força de decisão proferida pelo Tribunal de Justiça de São Paulo, a referida lei foi considerada inconstitucional.
} 
A questão da captação de recursos nos leva à discussão sobre as principais alterações que têm sido debatidas na Câmara dos Deputados no que tange a regulação do serviço de radiodifusão comunitária. Em setembro de 2008, 28 proposições referentes ao tema encontravam-se tramitando. Dessas, oito eram referentes à questão do financiamento das rádios, que, de acordo com a Lei $n^{\circ} 9.612 / 2008$, deveria ocorrer sob a forma de apoio cultural, este definido, de acordo com a Norma Complementar $\mathrm{n}^{\circ}$ 1/2004, como "o pagamento dos custos relativos a transmissão da programação ou de um programa específico, mediante a divulgação de mensagens institucionais da entidade apoiadora”.

No entanto, alguns parlamentares entendem que esse apoio cultural se mostra insuficiente para a manutenção e desenvolvimento das rádios. O PL 1513/1999 já buscava permitir a inserção de peças publicitárias na programação das emissoras de radiodifusão comunitária, desde que restrito a estabelecimentos na área da comunidade, sendo vedada a publicidade de qualquer órgão ou entidade da Administração Pública. De acordo com seu autor, Luiz Bittencourt (PMDB/GO), a rigidez da legislação atual leva as emissoras, pela absoluta falta de recursos, a buscar formas de apoio indevidas, gerando assim vínculos prejudiciais à comunidade. Segundo Fernando Ferro (PT/PE), ao banir completamente a possibilidade de veicular propagandas, limitou-se, em demasia, a possibilidade de auto-financiamento das rádios. O PL 2105/2003, de sua autoria, propõe a liberação da veiculação de propagandas de estabelecimentos comerciais, que sejam considerados legalmente como Microempresas e Empresas de Pequeno Porte e instituídos na região de cobertura da rádio, pelo período máximo de seis minutos, não cumulativos, a cada hora de programação ${ }^{6}$. No mesmo sentido temos também Adelor Vieira (PMDB/SC), autor do PL 2189/2003, que enxergas nas comunitárias um canal de comunicação mais acessível do que as emissoras comerciais, tendo em vista que seu serviço não visa o lucro, favorecendo assim os comerciantes da região.

Uma solução apresentada por alguns parlamentares para a questão do financiamento é a utilização de recursos públicos. O PL 1594/2003, de Washington Luiz (PT/MA), autoriza as rádios a veicular publicidade e divulgação oficial da União em caráter oneroso. Assim, caberia à União destinar cinco por cento da sua verba publicitária anual para veiculação da publicidade em emissoras de RadCom. Outra

\footnotetext{
${ }^{6}$ O PL 6464/2002, de Clovis Ilgenfritz (PT/RS), também define um limite para a inserção publicitária, limitando esta a $20 \%$ do tempo de operação diária da rádio.
} 
alternativa defendida é a criação de um fundo próprio para auxiliar as rádios. O PL 6348/2002, de Walter Pinheiro (PT/BA), propõe a criação de fundo especial para execução de projetos com o intuito de promover o aparelhamento de emissoras educativas e comunitárias, bem como a ampliação de infra-estruturas, a formação de mão-de-obra e outras formas de incentivo. As receitas do fundo seriam provenientes da aplicação de 2\% dos recursos do Fundo de Fiscalização das Telecomunicações (Fistel) e, portanto, oriundas do próprio setor. A gestão do fundo seria por meio da atuação conjunta das administrações estaduais e municipais, do Ministério Público e do Conselho de Comunicação Social do Congresso Nacional, que passaria também a abrigar um representante das rádios comunitárias e educativas, cabendo ao Conselho a análise, aprovação e fiscalização dos projetos desenvolvidos com os recursos do fundo ${ }^{7}$. Já o PL 3269/2004, de Edson Duarte (PV/BA), prevê a criação de Fundo de Apoio à Radiodifusão Comunitária, para fins de custeio de atividades de desenvolvimento e de capacitação de recursos humanos, bem como para a aquisição de equipamentos. O fundo seria constituído, entre outras receitas, por 1\% do Fistel.

O problema em se prever o uso de recursos do Fistel é que a lei que criou este fundo estabelece, logo no seu artigo primeiro, que o mesmo "se destina a prover recursos para cobrir as despesas feitas pelo Governo Federal na execução da fiscalização dos serviços de telecomunicações". Segundo Vanderlei Assis (PP/SP), o Fistel arrecada R\$ 1,7 bilhão anuais, sendo apenas R\$ 350 milhões efetivamente gastos. Dessa forma, o uso de parte de seus recursos não prejudicaria a função inicial do fundo. No entanto, em seus pareceres sobre o PL 3269/2004, tanto Maria do Carmo Lara (PT/MG), quanto Sandes Júnior (PP/GO) consideraram ilegal o desvio de função dos recursos.

Outro ponto tocado por diversos projetos é o proselitismo, que aparece na discussão ligado à questão da divulgação pelas rádios de conteúdo religioso e políticopartidário. O PL 5669/2001, de Bispo Rodrigues (PL/RJ), bem como o PL 6851/2002, de Luiz Moreira (PFL/BA), visam suprimir o dispositivo que proíbe o proselitismo. Argumenta Bispo Rodrigues que este dispositivo é, além de inconstitucional, instrumento de censura. A questão religiosa aparece nos mais diversos graus: o PL 1665/2003, de Wladimir da Costa (PMDB/PA), não só visa permitir o proselitismo religioso como pretende obrigar as rádios a conceder uma hora de programação diária

\footnotetext{
${ }^{7}$ O PL 5872/2001, de autoria de Ana Corso (PT/RS), também propõe a inclusão de um representante das rádios comunitárias e televisões comunitárias na composição do Conselho de Comunicação Social.
} 
aos sábados e aos domingos no período compreendido entre as seis horas e as vinte horas para a veiculação de conteúdo religioso; o PL 1550/2003, de Fernando de Fabinho (PFL/BA), visa permitir a outorga do serviço de RadCom para instituições religiosas e político-partidárias, argumentando que segmentos comunitários religiosos e políticos têm muito a contribuir com a difusão social, artística e cultural da população; por fim, o PL 7046/2006, de Lincoln Portela (PL/MG), pretende conceder às emissoras o direito de veicular conteúdos estritamente religiosos.

Os projetos descritos no parágrafo anterior são uma afronta direta à Lei $\mathrm{n}^{\circ}$ 9.612/1998, casos onde o que se propõe é o total desvio das finalidades previstas para o serviço de RadCom. Pode-se argumentar que conceder algum espaço para programas religiosos estaria ligado à oportunidade de difusão de diferentes idéias e elementos culturais, mas emissoras exclusivamente religiosas abrem espaço para se veicular tudo, exceto conteúdo de interesse da comunidade. O único projeto ligado ao tema que visa reafirmar as bases da legislação vigente é o PL 2949/2000, assinado por diversos parlamentares e encabeçado por Walter Pinheiro (PT/BA) e Fernando Ferro (PT/PE), que proíbe as instituições co-partidárias e religiosas, assim como os organismos a elas vinculadas, de serem proprietários ou administradores de rádios comunitárias ${ }^{8}$.

A idéia por trás do PL 2949/2000, evitar o desvirtuamento das rádios comunitárias, está presente também no PL 2480/2007, do Professor Victorio Galli (PMDB/MT), que busca vedar a participação de pessoas condenadas por desenvolver atividade clandestina de radiodifusão na direção de sociedades civis e fundações autorizadas a prestar o serviço de RadCom, bem como no PL 3790/2008, de Edson Duarte (PV/BA), que busca proibir ocupantes de cargo público, ou no gozo de imunidade parlamentar, ou de foro especial de serem dirigentes de entidades de radiodifusão comunitária. Apesar da boa intenção do legislador, o PL 3790/2008 não apresenta mecanismos eficientes para a solução do problema, tendo em vista que os políticos podem controlar as rádios de forma indireta, exercendo influência sobre o dirigente legal. O que se deve fazer é proporcionar instrumentos para que as emissoras não fiquem dependentes de favores externos, tanto para conseguir sua licença de funcionamento, quanto para se manter, uma vez instalada.

\footnotetext{
${ }^{8}$ O PL 2949/2000 trata ainda de diversos outros assuntos, como a definição da potência máxima do significado da expressão "cobertura restrita", a distribuição das freqüências de transmissão e a criação da Comissão Estadual da Radiodifusão Comunitária, com a finalidade de prestar assessoramento técnico, bem como arbitrar litígios e conflitos de interesse.
} 
Três projetos possuem como princípio a busca por uma maior democratização das comunicações. Em 2005, Celso Russomanno (PP/SP) apresentou o PL 5172, visando autorizar as instituições de ensino superior a executar o serviço de RadCom, a fim de que sirva de laboratório para os alunos dos cursos de jornalismo, publicidade e propaganda, relações públicas, rádio e televisão. Segundo o parlamentar, embora a legislação em vigor já preveja a possibilidade das universidades serem autorizadas a executar serviços de radiodifusão, os custos envolvidos na instalação e manutenção da infra-estrutura de uma rádio educativa inviabilizam sua implantação pelas universidades. No substituto apresentado pelo Deputado Fernando Ferro (PT/PE) ficam autorizadas também a prestar o serviço de RadCom os centros de educação tecnológica e instituições de ensino médio.

Já o PL 480/2007, de Édio Lopes (PMDB/RR), autoriza as rádios comunitárias da Amazônia Legal a operarem em média potência, a uma maior altura do sistema irradiante e a retransmitirem as programações das Rádios Câmara e Senado. Na Comissão da Amazônia, Integração Nacional e de Desenvolvimento Regional, o projeto recebeu parecer pela aprovação, com duas emendas que estenderam as previsões da proposição aos municípios do Nordeste, sob o argumento de que a realidade dos habitantes da região também difere em muito das demais regiões brasileiras, necessitando que a legislação seja adaptada à sua realidade. Pelas razões expostas, foi sugerido na Comissão de Ciência e Tecnologia, Comunicação e Informática que a área de cobertura possa ser de até dez mil metros de raio a partir da antena transmissora.

Mais uma vez, a boa intenção do legislador não é convertida em mecanismos eficazes para a solução do problema, tendo em vista que a questão da diversidade entre as regiões é tratada de forma muito rasa - adaptar o serviço de radiodifusão comunitária se reduz aqui a aumentar a potência e a cobertura das rádios. Também não é de muita valia retransmitir as rádios da Câmara e do Senado. Nas palavras de Silas Câmara (PSC/AM), "entendemos que isso pode desvirtuar o principal objetivo desse tipo de meio de comunicação: o privilégio à informação local”.

Por fim, o PL 2490/2007, de Eduardo Valverde (PT/RP), busca estender às comunidades indígenas oficialmente reconhecidas pelo Poder Público o direito de prestarem o Serviço de RadCom, por meio de um pedido de habilitação simplificado. Segundo o projeto, “as regras atuais, ainda que de maneira indireta, excluem os povos indígenas da possibilidade de operarem rádios comunitárias, uma vez que as outorgas 
podem ser destinadas apenas a associações ou fundações comunitárias, que estejam regularmente instaladas em ambientes urbanos”.

Tabela 4 - Principais projetos de lei tramitando (Out/2008)

\begin{tabular}{|c|c|c|}
\hline Temática & Projetos de Lei & Autor \\
\hline Proselitismo religioso e & PL 2949/2000 & Walter Pinheiro - PT/BA \\
\cline { 3 - 3 } político & PL 5669/2001 & Bispo Rodrigues - PL/RJ \\
\cline { 3 - 3 } & PL 6851/2002 & Luiz Moreira - PFL/BA \\
\cline { 3 - 3 } & PL 1550/2003 & Fernando de Fabinho - PFL/BA \\
\cline { 3 - 3 } & PL 1665/2003 & Wladimir Costa - PMDB/PA \\
\cline { 3 - 3 } & PL 7046/2006 & Lincoln Portela - PL/MG \\
\hline Veiculação de publicidade & PL 1513/1999 & Luiz Bittencourt - PMDB/GO \\
\cline { 3 - 3 } & PL 1594/2003 & Washington Luiz - PT/MA \\
\cline { 3 - 3 } & PL 2105/2003 & Fernando Ferro - PT/PE \\
\cline { 3 - 3 } & PL 2189/2003 & Adelor Vieira - PMDB/SC \\
\hline Financiamento público & PL 6348/2002 & Walter Pinheiro - PT/BA \\
\cline { 3 - 3 } & PL 1594/2003 & Washington Luiz - PT/MA \\
\cline { 3 - 3 } & PL 3269/2004 & Edson Duarte - PV/BA \\
\hline Proteção às finalidades da & PL 2949/2000 & Walter Pinheiro - PT/BA \\
\cline { 3 - 3 } RadCom & PL 2480/2007 & Professor Victorio Galli - PMDB/MT \\
\cline { 3 - 3 } & PL 3790/2008 & Edson Duarte - PV/BA \\
\cline { 3 - 3 } & PL 5172/2005 & Celso Russomanno - PP/SP \\
\cline { 3 - 3 } & PL 480/2007 & Édio Lopes - PMDB/RR \\
\hline Democratização das & PL 2490/2007 & Eduardo Valverde - PT/RP \\
\hline comunicações & & \\
& &
\end{tabular}

Nada menos que 16 dos 28 projetos tramitando encontram-se apensados ao PL 4186/1998, de autoria de Arnaldo Faria de Sá (PPB/SP), proposição que por três vezes já foi arquivada, em 1999, 2003 e 2007, encontrando-se atualmente na Comissão de Ciência e Tecnologia, Comunicação e Informática (CCTCI). Proposta ampla, possuía originalmente como seus principais pontos o aumento da potência das emissoras de 25 watts ERP para 50 watts ERP; a ampliação do número de canais a ser ofertado às emissoras, atualmente restrito a um canal, em nível nacional, na faixa de freqüência modulada; supressão do parágrafo $1^{\circ}$ do art. $4^{\circ}$ da Lei $n^{\circ} 9.612 / 98$, que proíbe expressamente o proselitismo; eliminação da expressão "sob a forma de apoio cultural” no artigo que permite o patrocínio por parte de estabelecimentos situados na área de abrangência da emissora; tipificação da punição a ser imposta conforme a infração; e restrição a não proteção contra interferência aos casos de serviços essenciais, igualando as comunitárias às rádios comerciais. Apresentado poucos dias após a sanção da Lei 9.612/98, o projeto estabelecia ainda um prazo de 90 dias para que as emissoras já em 
funcionamento, mas sem a devida autorização, regularizassem sua situação, sem o risco de serem fechadas nesse período.

Em 24/4/08, foi apresentado por Maria do Carmo Lara (PT/MG) um amplo projeto substitutivo, que se mostra como a principal esperança de avanço na área, propondo: aumento da potência de 25 watts ERP para 50 watts ERP, e permitindo que haja uma certa discricionariedade do Poder Concedente para estabelecer a potência em casos específicos, levando-se em conta fatores técnicos e sócio-econômicos, tendo como parâmetros as potências de 100 watts ERP, 150 watts ERP ou 200 watts ERP; destinação de, no mínimo, três canais para o serviço de RadCom, por localidade; elaboração de uma política nacional para a área, por um conselho no qual está assegurada a participação de representantes da sociedade e dos operadores, além de representantes da Câmara e do Senado, bem como a formação de conselho estaduais, que teriam como finalidade levar ao Poder Público Federal, responsável pelas concessões, demandas mais focalizadas das diversas unidades da federação, de modo a catalisar o processo de consolidação do sistema de radiodifusão comunitária no País; a obrigatoriedade de expedição periódica de avisos de habilitação, num intervalo mínimo de quatro meses; a criação do Cadastro Nacional de Rádios Comunitárias, propiciando, por meio da Internet, a disponibilização de informações de interesse geral da sociedade e contribuindo para o aumento da transparência; a criação de uma espécie de ouvidoria, para o recebimento de sugestões e denúncias; fim da exigência de pré-sintonia pela Anatel na freqüência de operação consignada à emissora; a obrigatoriedade das emissoras de RadCom reservarem intervalo mínimo de cinco (minutos) em sua programação, intercalados ou não, para transmissão de programas produzidos por entidades sediadas na localidade, conforme sugestão constante no Projeto de Lei $\mathrm{n}^{\circ}$ 4.165, de autoria do senador e atual ministro das Comunicações, Hélio Costa; fim do veto à formação de rede, limitando as transmissões em cadeia a 15\% do total da programação, a fim de evitar abusos e perda do caráter local; a permissão de destinação de até $15 \%$ do total da programação para veiculação de publicidade ou patrocínio, distribuídos eqüitativamente ao longo de toda a grade, com a receita oriunda de propaganda sendo revertida para a manutenção da emissora; e a mudança na questão da não proteção contra interferência, restrita agora aos casos de serviços essenciais, igualando as comunitárias às rádios comerciais. Atualmente, o projeto encontra-se na CCTCI aguardando o parecer da Comissão. 


\section{Conclusão}

A discussão estabelecida nos capítulos anteriores nos permite detectar uma congruência entre as finalidades estabelecidas pela Lei $n^{0}$ 9.612/1998, a visão dos parlamentares a respeito da radiodifusão comunitária e o modo como esta se insere em um contexto de resgate da democracia. No entanto, fato é que o modo como serviço de radiodifusão comunitária foi implantado no Brasil acabou gerando dois espaços diferentes: o primeiro, quase utópico, abriga as experiências positivas, ou seja, comunidades que conseguiram implementar os objetivos previstos na legislação; o outro, mais realista, é composto por desvirtuamentos dos objetivos da radiodifusão comunitária, desdobramento até natural tendo em vista os aspectos da legislação descritos no Capítulo III, que apresentam mais entraves do que incentivos à implementação das rádios.

A tentativa de fortalecimento da democracia é explícita nos objetivos da Lei $\mathrm{n}^{\circ}$ 9612/2008, sendo seus Arts. $3^{\circ}$ e $4^{\circ}$ praticamente a institucionalização da noção de "reflective human agency" trabalhada no Capítulo I. Integração da comunidade, participação direta, capacitação dos indivíduos, transformação da sociedade, livre exercício da comunicação; todas essas noções estão presentes tanto na lei quanto no conceito deweyano. Considerando a noção de democracia desenvolvida neste trabalho, e olhando apenas para as finalidades e princípios da radiodifusão comunitária no Brasil, seria perfeitamente normal considerá-la como um agente democratizante.

O contraponto aos objetivos, princípios e finalidades estabelecidos em lei são os exemplos empíricos de desvirtuamento do serviço de RadCom, oriundos do modo sofrível como este foi implementado no Brasil. Em junho de 2007, o próprio presidente da Associação Brasileira de Radiodifusão Comunitária, José Guilherme Castro, reconheceu o problema: "Há 3 mil emissoras comunitárias, e só 10\% são de fato com fins sociais. O restante tem uso político. As rádios comunitárias são uma continuação do poder político” (Mazzini, 2007).

O principal problema é que a burocracia excessiva funciona como empecilho, dificultando o pedido de outorga e tornando lenta a tramitação dos processos, resultando não só em um alto nível de arquivamento como praticamente incentivando ações ilegais. Em média, para cada processo aprovado, cinco são arquivados, sendo a maior parte deles por razões burocráticas e não técnicas (Lima e Lopes, 2007). Segundo pesquisa 
“Rádios comunitárias: Coronelismo eletrônico de novo tipo (1999-2004)”, realizada por Venício Artur de Lima e Cristiano Aguiar Lopes, de 4.878 processos de outorga arquivados entre agosto de 1998 e maio de 2004, mais de 80\% tiveram como causa do arquivamento o não-cumprimento de alguma exigência burocrática, como a não apresentação de documentos exigidos no aviso de habilitação (2007). Ainda segundo os mesmos pesquisadores, “dos 1.822 processos que não tinham um 'padrinho político', apenas 146 foram aprovados - uma taxa de sucesso de 8,01\%. Já dos 1.010 processos apadrinhados, 357 foram aprovados - uma taxa de sucesso de 35,34\%”.

O “apadrinhamento” funciona em dois níveis. O primeiro, que não pode por si só ser considerado ilegal, consiste em um assessoramento por parte de políticos, instruindo as associações comunitárias e disponibilizando recursos financeiros e técnicos a fim de se reunir toda a documentação necessária para a aprovação da outorga. O segundo, por sua vez, está ligado ao encaminhamento dos processos iniciados no Ministério das Comunicações ao Congresso Nacional, que ocorre por meio de uma mensagem presidencial, após tramitarem na Presidência da República - Casa Civil/SRI. A pesquisa supracitada constatou uma enorme diferença no tempo necessário para o encaminhamento dos processos.

Segundo Lima e Lopes, “para os 86 processos apadrinhados por políticos do Partido dos Trabalhadores, a média de tempo de tramitação na Presidência da República - Casa Civil/SRI foi de 280 dias. Já para os 184 processos apadrinhados pela base aliada, esse tempo foi de 326 dias. E para os 44 processos de interesse da oposição, o tempo médio de tramitação subiu para 374 dias”. Indo além, olhando a dispersão dos tempos de tramitação, fica evidente na pesquisa que houve um claro privilégio para alguns processos, bem como uma clara retenção de outros. Como apontam os pesquisadores, as razões para essa prática ficam evidentes quando se percebe que o envio ao Congresso Nacional passou a ser praticamente a liberação tácita de funcionamento de uma rádio, considerando que o Legislativo raramente cumpre o prazo de 90 dias para deliberação a respeito da outorga. Já a retenção de um processo significa praticamente sua negação, tendo em vista que a contagem do prazo se dá apenas após o envio do processo ao Congresso Nacional.

O modo como funciona o processo de liberação das outorgas contribui, então, para perigosas e ilegais relações entre rádios comunitárias e políticos, mensuradas de forma aproximada pela pesquisa de Lima e Lopes. Segundo os autores, “entre as 2.205 rádios comunitárias integrantes da amostra (rádios comunitárias outorgadas entre 1999 e 
2004), foi possível detectar vínculos políticos em 1.106 (50,2\%); dos 1.106 casos detectados em que havia vínculo político, exatos 1.095 (99\%) eram relativos a um ou mais políticos que atuam em nível municipal”. Os casos restantes são referentes a vínculos com políticos que atuam no âmbito do estado, não sendo encontrado nenhum caso de vínculo entre rádios comunitárias e deputados federais ou senadores. Foram encontradas, ainda, 120 rádios (5,4\% do total) com algum tipo de vínculo religioso.

O primeiro ponto a se observar é que durante toda a pesquisa para a realização desta monografia não foi possível detectar notícia de uma única medida por parte do executivo federal que visasse combater a associação entre políticos e rádios comunitárias; o foco de repressão do governo está claramente nas rádios irregulares, chamadas “piratas”, fortemente perseguidas pela Polícia Federal e Anatel, conforme discutido no Capítulo II. É certo que algumas dessas rádios estão associadas com políticos, assim como também é certo que outras tantas são rádios independentes, perdidas no universo de quatro mil entidades que aguardam autorização de funcionamento. Enquanto essas rádios são fechadas, nada é feito para caçar as outorgas de rádios ligadas direta ou indiretamente à políticos.

O outro ponto importante é a direção em que aponta os processos de lei que se encontram tramitando na Câmara dos Deputados; em outros termos, sua "não-direção". É fato que existem alguns projetos que merecem destaque, como o PL 2490/2007, que busca estender às comunidades indígenas o direito de prestarem o Serviço de RadCom; os PLs 6464/2002 e 2189/2003, que buscam estipular uma nova fonte de renda para as rádios, sem estabelecer vínculo das mesmas com o governo; e os PLs 2949/2000 e 3790/2008, que visam combater, respectivamente, o proselitismo e a participação direta na direção de rádios de ocupantes de cargo público ou no gozo de imunidade parlamentar. No entanto, a grande maioria dos projetos, conforme descrito no Capítulo III, simplesmente não contribui para o desenvolvimento das rádios. Pior: nenhum projeto em tramitação visa modificar o processo de outorga, deixando intocado aquele que desponta como o principal empecilho ao desenvolvimento da radiodifusão comunitária.

A Deputada Maria do Carmo Lara (PT/MG) é precisa em sintetizar a questão, em parecer sobre o PL 4186/1998 na Comissão de Ciência, Tecnologia, Comunicação e Informática: 
“Se, ideologicamente, o modelo [de radiodifusão comunitária] foi bem concebido, o formato mostrou-se incompatível com a realidade do País. Desde a promulgação, a Lei de Radiodifusão Comunitária é deliberadamente restritiva e burocrática. As exigências formais são excessivas e o processo é ritualístico ao extremo, além de eivado de vícios políticos. As restrições legais aqui expostas; a morosidade dos processos, a lentidão do Poder Executivo em lançar comunicados de habilitação com regularidade; o número excessivo de processos arquivados - mais de 6.500, contra um total de 2.867 entidades autorizadas -, muitos por mera exigência burocrática, são alguns dos problemas que estão minando o crescimento saudável de um sistema de rádio comunitária no Brasil. O fortalecimento das rádios comunitárias é um bom caminho para a consolidação de nossa democracia, para o incentivo à nossa diversidade cultural e para o desenvolvimento de nossas regiões.”

Enquanto não for feita uma séria revisão da legislação, incluindo no debate não apenas questões ligadas ao modo de operação das rádios - altura de antenas, potência, espectro magnético - mas sim o modo como se dá o próprio rito de concessão, a radiodifusão comunitária estará fadada a ser um potencial, como outros tantos “se...” da história do nosso país. 


\section{ANEXO A - Lei $n^{\circ}$ 9.612/2008}

\section{O PRESIDENTE DA REPÚBLICA}

Faço saber que o Congresso Nacional decreta e eu sanciono a seguinte Lei:

Art. $1^{\circ}$ Denomina-se Serviço de Radiodifusão Comunitária a radiodifusão sonora, em freqüência modulada, operada em baixa potência e cobertura restrita, outorgada a fundações e associações comunitárias, sem fins lucrativos, com sede na localidade de prestação do serviço.

$\S 1^{\circ}$ Entende-se por baixa potência o serviço de radiodifusão prestado a comunidade, com potência limitada a um máximo de 25 watts ERP e altura do sistema irradiante não superior a trinta metros.

$\S 2^{\circ}$ Entende-se por cobertura restrita aquela destinada ao atendimento de determinada comunidade de um bairro e/ou vila.

Art. $2^{0}$ O Serviço de Radiodifusão Comunitária obedecerá ao disposto no art. 223 da Constituição, aos preceitos desta Lei e, no que couber, aos mandamentos da Lei ${ }^{\circ}$ 4.117, de 27 de agosto de 1962, e demais disposições legais. (Redação dada pela Medida Provisória n $2.216-37$, de 2001)

Parágrafo único. Autorizada a execução do serviço e, transcorrido o prazo previsto no art. 64, $\S \S 2^{0}$ e $4^{\circ}$ da Constituição, sem apreciação do Congresso Nacional, o Poder Concedente expedirá autorização de operação, em caráter provisório, que perdurará até a apreciação do ato de outorga pelo Congresso Nacional. (Redação dada pela Medida Provisória $\mathrm{n}^{\circ}$ 2.216-37, de 2001)

Art. $3^{\circ} \mathrm{O}$ Serviço de Radiodifusão Comunitária tem por finalidade o atendimento à comunidade beneficiada, com vistas a:

I - dar oportunidade à difusão de idéias, elementos de cultura, tradições e hábitos sociais da comunidade;

II - oferecer mecanismos à formação e integração da comunidade, estimulando o lazer, a cultura e o convívio social;

III - prestar serviços de utilidade pública, integrando-se aos serviços de defesa civil, sempre que necessário;

IV - contribuir para o aperfeiçoamento profissional nas áreas de atuação dos jornalistas e radialistas, de conformidade com a legislação profissional vigente;

V - permitir a capacitação dos cidadãos no exercício do direito de expressão da forma mais acessível possível. 
Art. $4^{\circ}$ As emissoras do Serviço de Radiodifusão Comunitária atenderão, em sua programação, aos seguintes princípios:

I - preferência a finalidades educativas, artísticas, culturais e informativas em benefício do desenvolvimento geral da comunidade;

II - promoção das atividades artísticas e jornalísticas na comunidade e da integração dos membros da comunidade atendida;

III - respeito aos valores éticos e sociais da pessoa e da família, favorecendo a integração dos membros da comunidade atendida;

IV - não discriminação de raça, religião, sexo, preferências sexuais, convicções político-ideológico-partidárias e condição social nas relações comunitárias.

$\S 1^{\circ}$ É vedado o proselitismo de qualquer natureza na programação das emissoras de radiodifusão comunitária.

$\S 2^{\circ}$ As programações opinativa e informativa observarão os princípios da pluralidade de opinião e de versão simultâneas em matérias polêmicas, divulgando, sempre, as diferentes interpretações relativas aos fatos noticiados.

$\S 3^{\circ}$ Qualquer cidadão da comunidade beneficiada terá direito a emitir opiniões sobre quaisquer assuntos abordados na programação da emissora, bem como manifestar idéias, propostas, sugestões, reclamações ou reivindicações, devendo observar apenas o momento adequado da programação para fazê-lo, mediante pedido encaminhado à Direção responsável pela Rádio Comunitária.

Art. 5 O Poder Concedente designará, em nível nacional, para utilização do Serviço de Radiodifusão Comunitária, um único e específico canal na faixa de freqüência do serviço de radiodifusão sonora em freqüência modulada.

Parágrafo único. Em caso de manifesta impossibilidade técnica quanto ao uso desse canal em determinada região, será indicado, em substituição, canal alternativo, para utilização exclusiva nessa região.

Art. $6^{\circ}$ Compete ao Poder Concedente outorgar à entidade interessada autorização para exploração do Serviço de Radiodifusão Comunitária, observados os procedimentos estabelecidos nesta Lei e normas reguladoras das condições de exploração do Serviço.

Parágrafo único. A outorga terá validade de dez anos, permitida a renovação por igual período, se cumpridas as exigências desta Lei e demais disposições legais vigentes.(Redação dada pela Lei $n^{0} 10.597$, de 2002)

Art. $7^{\circ}$ São competentes para explorar o Serviço de Radiodifusão Comunitária as fundações e associações comunitárias, sem fins lucrativos, desde que legalmente instituídas e devidamente registradas, sediadas na área da comunidade para a qual pretendem prestar o Serviço, e cujos dirigentes sejam brasileiros natos ou naturalizados há mais de 10 anos. 
Parágrafo único. Os dirigentes das fundações e sociedades civis autorizadas a explorar o Serviço, além das exigências deste artigo, deverão manter residência na área da comunidade atendida.

Art. $8^{\circ}$ A entidade autorizada a explorar o Serviço deverá instituir um Conselho Comunitário, composto por no mínimo cinco pessoas representantes de entidades da comunidade local, tais como associações de classe, beneméritas, religiosas ou de moradores, desde que legalmente instituídas, com o objetivo de acompanhar a programação da emissora, com vista ao atendimento do interesse exclusivo da comunidade e dos princípios estabelecidos no art. $4^{\circ}$ desta Lei.

Art. $9^{\circ}$ Para outorga da autorização para execução do Serviço de Radiodifusão Comunitária, as entidades interessadas deverão dirigir petição ao Poder Concedente, indicando a área onde pretendem prestar o serviço.

$\S 1^{\circ}$ Analisada a pretensão quanto a sua viabilidade técnica, o Poder Concedente publicará comunicado de habilitação e promoverá sua mais ampla divulgação para que as entidades interessadas se inscrevam.

$\S 2^{\circ}$ As entidades deverão apresentar, no prazo fixado para habilitação, os seguintes documentos: I - estatuto da entidade, devidamente registrado;

II - ata da constituição da entidade e eleição dos seus dirigentes, devidamente registrada;

Ill - prova de que seus diretores são brasileiros natos ou naturalizados há mais de dez anos;

IV - comprovação de maioridade dos diretores;

V - declaração assinada de cada diretor, comprometendo-se ao fiel cumprimento das normas estabelecidas para o serviço;

VI - manifestação em apoio à iniciativa, formulada por entidades associativas e comunitárias, legalmente constituídas e sediadas na área pretendida para a prestação do serviço, e firmada por pessoas naturais ou jurídicas que tenham residência, domicílio ou sede nessa área.

$\S 3^{\circ}$ Se apenas uma entidade se habilitar para a prestação do Serviço e estando regular a documentação apresentada, o Poder Concedente outorgará a autorização à referida entidade.

$\S 4^{\circ}$ Havendo mais de uma entidade habilitada para a prestação do Serviço, o Poder Concedente promoverá o entendimento entre elas, objetivando que se associem.

$\S 5^{\circ}$ Não alcançando êxito a iniciativa prevista no parágrafo anterior, o Poder Concedente procederá à escolha da entidade levando em consideração o critério da representatividade, evidenciada por meio de manifestações de apoio encaminhadas por membros da comunidade a ser atendida e/ou por associações que a representem. 
$\S 6^{\circ}$ Havendo igual representatividade entre as entidades, proceder-se-á à escolha por sorteio.

Art. 10. A cada entidade será outorgada apenas uma autorização para exploração do Serviço de Radiodifusão Comunitária.

Parágrafo único. É vedada a outorga de autorização para entidades prestadoras de qualquer outra modalidade de Serviço de Radiodifusão ou de serviços de distribuição de sinais de televisão mediante assinatura, bem como à entidade que tenha como integrante de seus quadros de sócios e de administradores pessoas que, nestas condições, participem de outra entidade detentora de outorga para exploração de qualquer dos serviços mencionados.

Art. 11. A entidade detentora de autorização para execução do Serviço de Radiodifusão Comunitária não poderá estabelecer ou manter vínculos que a subordinem ou a sujeitem à gerência, à administração, ao domínio, ao comando ou à orientação de qualquer outra entidade, mediante compromissos ou relações financeiras, religiosas, familiares, político-partidárias ou comerciais.

Art. 12. É vedada a transferência, a qualquer título, das autorizações para exploração do Serviço de Radiodifusão Comunitária.

Art. 13. A entidade detentora de autorização pala exploração do Serviço de Radiodifusão Comunitária pode realizar alterações em seus atos constitutivos e modificar a composição de sua diretoria, sem prévia anuência do Poder Concedente, desde que mantidos os termos e condições inicialmente exigidos para a outorga da autorização, devendo apresentar, para fins de registro e controle, os atos que caracterizam as alterações mencionadas, devidamente registrados ou averbados na repartição competente, dentro do prazo de trinta dias contados de sua efetivação.

Art. 14. Os equipamentos de transmissão utilizados no Serviço de Radiodifusão Comunitária serão pré-sintonizados na freqüência de operação designada para o serviço e devem ser homologados ou certificados pelo Poder Concedente.

Art. 15. As emissoras do Serviço de Radiodifusão Comunitária assegurarão, em sua programação, espaço para divulgação de planos e realizações de entidades ligadas, por suas finalidades, ao desenvolvimento da comunidade.

Art. 16. É vedada a formação de redes na exploração do Serviço de Radiodifusão Comunitária, excetuadas as situações de guerra, calamidade pública e epidemias, bem como as transmissões obrigatórias dos Poderes Executivo, Judiciário e Legislativo definidas em leis.

Art. 17. As emissoras do Serviço de Radiodifusão Comunitária cumprirão tempo mínimo de operação diária a ser fixado na regulamentação desta Lei.

Art. 18. As prestadoras do Serviço de Radiodifusão Comunitária poderão admitir patrocínio, sob a forma de apoio cultural, para os programas a serem transmitidos, desde que restritos aos estabelecimentos situados na área da comunidade atendida. 
Art. 19. É vedada a cessão ou arrendamento da emissora do Serviço de Radiodifusão Comunitária ou de horários de sua programação.

Art. 20. Compete ao Poder Concedente estimular o desenvolvimento de Serviço de Radiodifusão Comunitária em todo o território nacional, podendo, para tanto, elaborar Manual de Legislação, Conhecimentos e Ética para uso das rádios comunitárias e organizar cursos de treinamento, destinados aos interessados na operação de emissoras comunitárias, visando o seu aprimoramento e a melhoria na execução do serviço.

Art. 21. Constituem infrações - operação das emissoras do Serviço de Radiodifusão Comunitária:

I - usar equipamentos fora das especificações autorizadas pelo Poder Concedente;

II - transferir a terceiros os direitos ou procedimentos de execução do Serviço;

III - permanecer fora de operação por mais de trinta dias sem motivo justificável;

IV - infringir qualquer dispositivo desta Lei ou da correspondente regulamentação;

Parágrafo único. As penalidades aplicáveis em decorrência das infrações cometidas são:

I - advertência;

Il - multa; e

III - na reincidência, revogação da autorização.

Art. 22. As emissoras do Serviço de Radiodifusão Comunitária operarão sem direito a proteção contra eventuais interferências causadas por emissoras de quaisquer Serviços de Telecomunicações e Radiodifusão regularmente instaladas, condições estas que constarão do seu certificado de licença de funcionamento.

Art. 23. Estando em funcionamento a emissora do Serviço de Radiodifusão Comunitária, em conformidade com as prescrições desta Lei, e constatando-se interferências indesejáveis nos demais Serviços regulares de Telecomunicações e Radiodifusão, o Poder Concedente determinará a correção da operação e, se a interferência não for eliminada, no prazo estipulado, determinará a interrupção do serviço.

Art. 24. A outorga de autorização para execução do Serviço de Radiodifusão Comunitária fica sujeita a pagamento de taxa simbólica, para efeito de cadastramento, cujo valor e condições serão estabelecidos pelo Poder Concedente.

Art. 25. O Poder Concedente baixará os atos complementares necessários à regulamentação do Serviço de Radiodifusão Comunitária, no prazo de cento e vinte dias, contados da publicação desta Lei.

Art. 26. Esta Lei entra em vigor na data de sua publicação. 
Art. 27. Revogam-se as disposições em contrário.

Brasília, 19 de fevereiro de 1998; $177^{\circ}$ da Independência e $110^{\circ}$ da República.

FERNANDO HENRIQUE CARDOSO

Sergio Motta 


\section{ANEXO B - Decreto $n^{\circ}$ 2.615/1998}

Aprova o Regulamento do Serviço de Radiodifusão Comunitária.

O PRESIDENTE DA REPÚBLICA, no uso das atribuições que lhe confere o art. 84, inciso IV, da Constituição, e tendo em vista o disposto na Lei no 9.612, de 19 de fevereiro de 1998,

D E C R E T A :

Art. $1^{\circ}$ Fica aprovado, na forma do Anexo a este Decreto, o Regulamento do Serviço de Radiodifusão Comunitária, que com este baixa.

Art. $2^{\circ}$ Este Decreto entra em vigor na data de sua publicação.

Brasília, 03 de junho de 1998; $177^{\circ}$ da Independência e $110^{\circ}$ da República.

ANEXO

REGULAMENTO DO SERVIÇO DE RADIODIFUSÃO COMUNITÁRIA

CAPÍTULO I

DAS GENERALIDADES

Art. $1^{\circ}$ Este Regulamento dispõe sobre o Serviço de Radiodifusão Comunitária RadCom, instituído pela Lei no 9.612, de 19 de fevereiro de 1998, como um Serviço de Radiodifusão Sonora, com baixa potência e com cobertura restrita, para ser executado por fundações e associações comunitárias, sem fins lucrativos, com sede na localidade de prestação do Serviço.

Art. $2^{\circ}$ As condições para execução do RadCom subordinam-se ao disposto no art. 223 da Constituição Federal, à Lei no 9.612, de 1998 e, no que couber, à Lei nº4.117, de 27 de agosto de 1962, modificada pelo Decreto-Lei no 236, de 28 de fevereiro de 1967, e à regulamentação do Serviço de Radiodifusão Sonora, bem como a este Regulamento, às normas complementares, aos tratados, aos acordos e aos atos internacionais.

Art. $3^{\circ} \mathrm{O}$ RadCom tem por finalidade o atendimento de determinada comunidade, com vistas a:

I - dar oportunidade à difusão de idéias, elementos de cultura, tradições e hábitos sociais da comunidade;

II - oferecer mecanismos à formação e integração da comunidade, estimulando o lazer, a cultura e o convívio social;

III - prestar serviços de utilidade pública, integrando-se aos serviços de defesa civil, sempre que necessário;

IV - contribuir para o aperfeiçoamento profissional nas áreas de atuação dos jornalistas 
e radialistas, de conformidade com a legislação profissional vigente;

V - permitir a capacitação dos cidadãos no exercício do direito de expressão, da forma mais acessível possível.

Art. $4^{\circ}$ A Agência Nacional de Telecomunicações - ANATEL designará um único e específico canal na faixa de freqüências do Serviço de Radiodifusão Sonora em Freqüência Modulada, para atender, em âmbito nacional, ao Serviço de que trata este Regulamento.

Parágrafo único. Em caso de manifesta impossibilidade técnica quanto ao uso desse canal em determinada região, a ANATEL indicará, em substituição, canal alternativo, para utilização exclusiva naquela região, desde que haja algum que atenda aos critérios de proteção dos canais previstos nos Planos Básicos de Distribuição de Canais de Radiodifusão Sonora em Freqüência Modulada, de Televisão em VHF e de Retransmissão de Televisão em VHF.

Art. $5^{\circ}$ A potência efetiva irradiada por emissora do RadCom será igual ou inferior a vinte e cinco watts.

Art. $6^{\circ}$ A cobertura restrita de uma emissora do RadCom é a área limitada por um raio igual ou inferior a mil metros a partir da antena transmissora, destinada ao atendimento de determinada comunidade de um bairro, uma vila ou uma localidade de pequeno porte.

Art. $7^{\circ} \mathrm{O}$ Ministério das Comunicações estabelecerá, no comunicado de habilitação de que trata $\mathrm{o} \S \mathrm{l}^{\circ}$ do art. $9^{\circ}$ da Lei $\mathrm{n}^{\circ} 9.612$, de 1998 , o valor da taxa relativa ao cadastramento da emissora, bem como as condições de seu pagamento.

\section{CAPÍTULO II}

DAS DEFINIÇÕES

Art. $8^{\circ}$ Para os efeitos deste Regulamento, são adotadas as seguintes definições:

I - Licença para Funcionamento de Estação: é o documento que habilita a estação a funcionar em caráter definitivo, e que explicita a condição de não possuir a emissora direito à proteção contra interferências causadas por estações de telecomunicações e de radiodifusão regularmente instaladas;

II - Localidade de pequeno porte: é toda cidade ou povoado cuja área urbana possa estar contida nos limites de uma área de cobertura restrita;

III - Interferência indesejável: é a interferência que prejudica, de modo levemente perceptível, o serviço prestado por uma estação de telecomunicações ou de radiodifusão regularmente instalada;

IV - Interferência prejudicial: é a interferência que, repetida ou continuamente, prejudica ou interrompe o serviço prestado por uma estação de telecomunicações ou de radiodifusão regularmente instalada. 


\section{CAPÍTULO III \\ DA COMPETÊNCIA}

Art. $9^{\circ}$ Compete ao Ministério das Comunicações:

I - estabelecer as normas complementares do RadCom, indicando os parâmetros técnicos de funcionamento das estações, bem como detalhando os procedimentos para expedição de autorização e licenciamento;

II - expedir ato de autorização para a execução do Serviço, observados os procedimentos estabelecidos na Lei n ${ }^{\circ}$ 9.612, de 1998 e em norma complementar;

III - fiscalizar a execução do RadCom, em todo o território nacional, no que disser respeito ao conteúdo da programação, nos termos da legislação pertinente;

Art. 10. Compete à ANATEL:

I - designar, em nível nacional, para utilização do RadCom, um único e específico canal na faixa de freqüências do Serviço de Radiodifusão Sonora em Freqüência Modulada;

II - designar canal alternativo nas regiões onde houver impossibilidade técnica de uso do canal em nível nacional;

III - certificar os equipamentos de transmissão utilizados no RadCom;

IV - fiscalizar a execução do RadCom, em todo o território nacional, no que disser respeito ao uso do espectro radioelétrico.

\section{CAPÍTULO IV}

DA AUTORIZAÇÃO

Art. 11. São competentes para executar o RadCom fundações e associações comunitárias, sem fins lucrativos, desde que legalmente instituídas e devidamente registradas, sediadas na área da comunidade para a qual pretendem prestar o Serviço, e cujos dirigentes sejam brasileiros natos ou naturalizados há mais de dez anos.

Parágrafo único. Os dirigentes das fundações e sociedades civis autorizadas a executar o Serviço, além das exigências deste artigo, deverão manter residência na área da comunidade atendida.

Art. 12. As entidades interessadas em executar o RadCom deverão apresentar requerimento ao Ministério das Comunicações, demonstrando seu interesse, indicando a área onde pretendem prestar o Serviço e solicitando a designação de canal para a respectiva prestação.

Parágrafo único. A ANATEL procederá a análise da viabilidade técnica para uso do canal nacionalmente designado para o RadCom ou de canal alternativo, conforme disposto no art. $4^{\circ}$ e no inciso I do art. 10 deste Regulamento.

Art. 13. Havendo possibilidade técnica para o uso do canal específico ou de canal 
alternativo, o Ministério das Comunicações publicará, no Diário Oficial da União, comunicado de habilitação para inscrição das entidades interessadas, estabelecendo prazo para que o façam, bem como informando o valor e as condições de pagamento da taxa relativa às despesas de cadastramento.

Art. 14. As entidades interessadas na execução do RadCom, inclusive aquela cuja petição originou o comunicado de habilitação, deverão apresentar ao Ministério das Comunicações, no prazo fixado no comunicado de habilitação, os documentos a seguir indicados, além de atender as disposições estabelecidas em norma complementar:

I - estatuto da entidade, devidamente registrado;

II - ata da constituição da entidade e eleição dos seus dirigentes, devidamente registrada;

III - prova de que seus diretores são brasileiros natos, ou naturalizados há mais de dez anos;

IV - comprovação de maioridade dos diretores;

V - declaração assinada de cada diretor, comprometendo-se ao fiel cumprimento das normas estabelecidas para o Serviço;

VI - manifestação em apoio à iniciativa, formulada por entidades associativas e comunitárias, legalmente constituídas e sediadas na área pretendida para a prestação do Serviço, e firmada por pessoas naturais ou jurídicas que tenham residência, domicílio ou sede nessa área.

Art. 15. Se apenas uma entidade se habilitar para a prestação do Serviço, estando regular a documentação apresentada, o Ministério das Comunicações expedirá autorização à referida entidade.

Art. 16. Havendo mais de uma entidade habilitada para a prestação do Serviço, o Ministério das Comunicações promoverá o entendimento entre elas, objetivando que se associem. Não alcançando êxito, será procedida a escolha pelo critério de representatividade, evidenciada por meio de manifestações de apoio encaminhadas por membros ou por associações da comunidade a ser atendida.

Parágrafo único. Havendo igual representatividade entre as entidades, proceder-se-á à escolha por sorteio.

Art. 17. A autorização terá validade de três anos, permitida a renovação por igual período, se cumpridas as disposições legais vigentes.

Art. 18. A cada entidade será expedida apenas uma autorização para execução do RadCom.

Parágrafo único. É vedada a expedição de autorização para entidades prestadoras de qualquer outra modalidade de serviço de radiodifusão ou de serviços de distribuição de sinais de televisão mediante assinatura, bem como a entidade que tenha como integrante de seus quadros de sócios e de administradores pessoas que, nestas condições, 
participem de outra entidade detentora de outorga para execução de qualquer dos serviços mencionados.

\section{CAPÍTULO V \\ DA FORMALIZAÇÃO DA AUTORIZAÇÃO}

Art. 19. A autorização para execução do RadCom será formalizada mediante ato do Ministério das Comunicações, que deverá conter, pelo menos, a denominação da entidade, o objeto e o prazo da autorização, a área de cobertura da emissora e o prazo para início da execução do Serviço.

Art. 20. O Ministério das Comunicações providenciará a publicação, no Diário Oficial da União, do resumo do ato de autorização, como condição indispensável para sua eficácia, nos termos dos instrumentos aplicáveis.

\section{CAPÍTULO VI}

\section{DA INSTALAÇÃO DE EMISSORA DO SERVIÇO DE RADIODIFUSÃO COMUNITÁRIA}

Art. 21. As condições necessárias à instalação da emissora, bem como o prazo para o início efetivo da execução do RadCom, serão estabelecidos pelo Ministério das Comunicações em norma complementar.

Parágrafo único. O prazo mencionado neste artigo será contado a partir da data de publicação do ato de autorização.

Art. 22. Dentro do prazo que lhe é concedido para iniciar a execução do Serviço, a entidade deverá requerer a emissão de Licença para Funcionamento de Estação, devendo instruir o requerimento de acordo com o estabelecido em norma complementar.

\section{CAPÍTULO VII \\ DA EXECUÇÃO DO SERVIÇO}

Art. 23. O Ministério das Comunicações disporá, em norma complementar, sobre as características de operação das emissoras do RadCom.

Art. 24. Os equipamentos utilizados no RadCom serão certificados pela ANATEL, devendo ser pré-sintonizados na freqüência de operação consignada à emissora.

Art. 25. A emissora do RadCom operará sem direito a proteção contra eventuais interferências causadas por estações de Serviços de Telecomunicações e de Radiodifusão regularmente instaladas.

Art. 26. Caso uma emissora do RadCom provoque interferência indesejável nos demais Serviços regulares de Telecomunicações e de Radiodifusão, a ANATEL determinará a interrupção do serviço da emissora de RadCom interferente, no prazo fixado em norma complementar, até a completa eliminação da causa da interferência.

Art. 27. Caso uma emissora do RadCom provoque interferência prejudicial nos demais Serviços regulares de Telecomunicações e de Radiodifusão, a ANATEL determinará a 
imediata interrupção do seu funcionamento, até a completa eliminação da causa da interferência.

Art. 28. As emissoras do RadCom cumprirão período de oito horas, contínuas ou não, como tempo mínimo de operação diária.

Art. 29. É vedada a formação de redes na execução do RadCom, excetuadas as situações de guerra, calamidade pública e epidemias, bem como as transmissões obrigatórias dos Poderes Executivo, Judiciário e Legislativo, definidas em lei.

\section{CAPÍTULO VIII \\ DA PROGRAMAÇÃO}

Art. 30. As emissoras do RadCom atenderão, em sua programação, aos seguintes princípios:

I - preferência a finalidades educativas, artísticas, culturais e informativas, em benefício do desenvolvimento geral da comunidade;

II - promoção das atividades artísticas e jornalísticas na comunidade, e da integração dos membros da comunidade atendida;

III - respeito aos valores éticos e sociais da pessoa e da família, favorecendo a integração dos membros da comunidade atendida;

IV - não discriminação de raça, religião, sexo, preferências sexuais, convicções políticoideológico-partidárias e condição social nas relações comunitárias.

$\S 1^{\circ}$ É vedado o proselitismo de qualquer natureza na programação das emissoras de radiodifusão comunitária.

$\S 2^{\circ}$ As programações opinativa e informativa observarão os princípios da pluralidade de opinião e de versão simultânea em matérias polêmicas, divulgando sempre as diferentes interpretações relativas aos fatos noticiados.

$\S 3^{\circ}$ Qualquer cidadão da comunidade beneficiada terá direito a emitir opiniões sobre quaisquer assuntos abordados na programação da emissora, bem como manifestar idéias, propostas, sugestões, reclamações ou reivindicações, devendo observar apenas o momento adequado da programação para fazê-lo, mediante pedido encaminhado à direção responsável pela rádio comunitária.

Art. 31. As emissoras do RadCom assegurarão, em sua programação, espaço para divulgação de planos e realizações de entidades ligadas, por suas finalidades, ao desenvolvimento da comunidade.

Art. 32. As prestadoras do RadCom poderão admitir patrocínio, sob a forma de apoio cultural, para os programas a serem transmitidos, desde que restritos aos estabelecimentos situados na área da comunidade atendida. 
Art. 33. É vedada a cessão ou arrendamento da emissora do RadCom ou de horários de sua programação.

\section{CAPÍTULO IX \\ DA TRANSFERÊNCIA DA AUTORIZAÇÃO}

Art. 34. É vedada a transferência da autorização para execução do RadCom, a qualquer título, nos termos do art. 12 da Lei ${ }^{\circ}$ 9.612, de 1998.

Art. 35. A entidade autorizada a executar o RadCom pode, sem anuência do Ministério das Comunicações, realizar alterações em seus atos constitutivos e modificar a composição de sua diretoria, desde que essas operações não impliquem alteração nos termos e condições inicialmente exigidos para a autorização, devendo apresentar ao Ministério das Comunicações os atos que caracterizam as alterações mencionadas, devidamente registrados ou averbados na repartição competente, para fins de registro e controle, no prazo de trinta dias contado de sua efetivação.

\section{CAPÍTULO X}

DA RENOVAÇÃO DA AUTORIZAÇÃO

Art. 36. A autorização para execução do RadCom poderá ser renovada por um outro período de três anos, desde que a autorizada apresente solicitação neste sentido com antecedência de três a um mês do seu termo final e que cumpra as exigências estabelecidas para tanto pelo Ministério das Comunicações.

Art. 37. A renovação da autorização para execução do RadCom implicará pagamento de valor relativo às despesas decorrentes deste ato.

\section{CAPÍTULO XI}

\section{DAS INFRAÇÕES E PENALIDADES}

Art. 38. As penalidades aplicáveis em razão de infringência a qualquer dispositivo da Lei $\mathrm{n}^{\circ}$ 9.612, de 1998, deste Regulamento e das normas aplicáveis ao RadCom são:

I - advertência;

II - multa; e

III - na reincidência, revogação da autorização.

$\S 1^{\circ}$ A pena de advertência poderá ser aplicada ao infrator primário quando incorrer em infração considerada de menor gravidade.

$\S 2^{\circ}$ Os valores das multas a serem aplicadas obedecerão aos critérios estabelecidos no art. 59 da Lei $n^{\circ} 4.117$, de 1962, com a redação que lhe deu o art. $3^{\circ}$ do Decreto-Lei $n^{\circ}$ 236, de 1967.

Art. 39. Antes da aplicação de penalidades, a autorizada será notificada para exercer seu direito de defesa, conforme o estabelecido na Lei $n^{\circ}$ 4.117, de 1962, sem prejuízo da apreensão cautelar de que trata o parágrafo único do seu art. 70, com a redação que lhe 
deu o art. $3^{\circ}$ do Decreto-Lei ${ }^{\circ} 236$, de 1967.

Art. 40. São puníveis com multa as seguintes infrações na operação das emissoras do RadCom:

I - transferência a terceiros dos direitos ou procedimentos de execução do Serviço;

II - permanência fora de operação por mais de trinta dias sem motivo justificável;

III - uso de equipamentos não certificados ou homologados pela ANATEL;

IV - manutenção, pela autorizada, no seu quadro diretivo, de dirigente com residência fora da área da comunidade atendida;

V - não manutenção do Conselho Comunitário, nos termos da Lei;

VI - estabelecimento ou manutenção de vínculos que subordinem a entidade ou a sujeitem à gerência, à administração, ao domínio, ao comando ou à orientação de qualquer outra entidade, mediante compromissos ou relações financeiras, religiosas, familiares, político-partidárias ou comerciais;

VII - não comunicação ao Ministério das Comunicações, no prazo de trinta dias, das alterações efetivadas nos atos constitutivos ou da mudança de sua diretoria;

VIII - modificação dos termos e das condições inicialmente atendidos para a expedição do ato de autorização;

IX - não destinação de espaço na programação disponível à divulgação de planos e realizações de entidades ligadas, por suas finalidades, ao desenvolvimento da comunidade;

X - formação de redes na exploração do RadCom;

XI - não integração a redes quando convocadas em situações de guerra, calamidade pública e epidemias;

XII - não integração a redes para as transmissões obrigatórias dos Poderes Executivo, Judiciário e Legislativo;

XIII - cessão ou arrendamento da emissora ou de horários de sua programação;

XIV - transmissão de patrocínio em desacordo com as normas legais pertinentes;

XV - transmissão de propaganda ou publicidade comercial a qualquer título;

XVI - desvirtuamento das finalidades do RadCom e dos princípios fundamentais da programação;

XVII - utilização de denominação de fantasia diversa da comunicada ao Ministério das Comunicações; 
XVIII - imposição de dificuldades à fiscalização do Serviço;

XIX - não manutenção em dia os registros da programação em texto e fitas, nos termos da regulamentação;

XX - uso de equipamentos fora das especificações constantes dos certificados emitidos pela ANATEL;

XXI - não obediência ao tempo de funcionamento da estação comunicado ao Ministério das Comunicações;

XXII - alteração das características constantes da Licença para Funcionamento de Estação, sem observância das formalidades estabelecidas;

XXIII - não solicitação, no prazo estabelecido, da expedição de Licença para Funcionamento de Estação;

XXIV - não observância do prazo estabelecido para início da execução do Serviço;

XXV - utilização de freqüência diversa da autorizada;

XXVI - início da execução do Serviço pela autorizada sem estar previamente licenciada;

XXVII - início da operação em caráter experimental pela autorizada, sem ter comunicado o fato no prazo estabelecido em norma complementar;

XXVIII - não comunicação de alteração do horário de funcionamento

XXIX - não cumprimento pela autorizada, no tempo estipulado, de exigência que lhe tenha sido feita pelo Ministério das Comunicações ou pela ANATEL.

\section{CAPÍTULO XII}

DA INTERRUPÇÃO DO SERVIÇO

Art. 41. A execução do RadCom será interrompida nos seguintes casos:

I - de imediato, na ocorrência de interferências prejudiciais;

II - no prazo estipulado pela ANATEL, na constatação de interferências indesejáveis, caso estas não tenham sido eliminadas;

III - quando estiver configurada situação de perigo de vida.

\section{CAPÍTULO XIII}

DAS DISPOSIÇÕES GERAIS

Art. 42. As entidades autorizadas a executar o RadCom estão sujeitas ao pagamento das taxas de fiscalização das telecomunicações previstas em lei. 
Art. 43. A entidade detentora de autorização para execução do RadCom não poderá estabelecer ou manter vínculos que a subordinem ou a sujeitem à gerência, à administração, ao domínio, ao comando ou à orientação de qualquer outra entidade, mediante compromissos ou relações financeiras, religiosas, familiares, políticopartidárias ou comerciais. 


\section{ANEXO C - Norma Complementar $n^{\circ}$ 2/1998}

\section{OBJETIVO}

Esta Norma tem por objetivo complementar as disposições relativas ao Serviço de Radiodifusão Comunitária - RadCom, instituído pela Lei n ${ }^{\circ}$ 9.612, de 19 de fevereiro de 1998, como um Serviço de Radiodifusão Sonora, com baixa potência e com cobertura restrita, para ser executado por fundações e associações comunitárias, sem fins lucrativos, com sede na localidade de prestação do Serviço, detalhando essas disposições e estabelecendo as condições técnicas de operação das estações do Serviço.

\section{REFERÊNCIAS BÁSICAS}

2.1 Lei n. ${ }^{\circ}$ 4.117, de 27 de agosto de 1962, modificada pelo Decreto-lei n. ${ }^{\circ}$ 236, de 28 de fevereiro de 1967.

2.2 Lei n. ${ }^{\circ}$ 9.612, de 19 de fevereiro de 1998, que institui o Serviço de Radiodifusão Comunitária.

2.3 Decreto n. ${ }^{\circ}$ 52.795, de 31 de outubro de 1963, que aprova o Regulamento dos Serviços de Radiodifusão, e suas alterações.

2.4 Decreto n. ${ }^{\circ}$ 2.615, de 3 de junho de 1998, que aprova o Regulamento do Serviço de Radiodifusão Comunitária.

2.5 Portaria nº 017, de 31 de janeiro de 1983, que dá nova redação à N-07/80 - Norma Técnica para a Execução do Serviço de Radiodifusão Sonora em Freqüência Modulada.

\section{DEFINIÇÕES}

Aplicam-se a esta Norma as definições estabelecidas na regulamentação do serviço de radiodifusão, em especial de radiodifusão sonora em freqüência modulada, além das indicadas a seguir:

I - Licença para Funcionamento de Estação: é o documento que habilita a estação a funcionar em caráter definitivo, e que explicita a condição de não possuir a emissora direito a proteção contra interferências causadas por estações de telecomunicações e de radiodifusão regularmente instaladas.

II - Localidade de pequeno porte: é toda cidade ou povoado cuja área urbana possa estar contida nos limites de uma área de cobertura restrita.

III - Interferência indesejável - é aquela que prejudica, de modo levemente perceptível, o serviço prestado por uma estação de telecomunicações ou de radiodifusão regularmente instalada. 
IV - Interferência prejudicial - é aquela que, repetida ou continuamente, prejudica ou interrompe o serviço prestado por uma estação de telecomunicações ou de radiodifusão regularmente instalada.

\section{FINALIDADE DO SERVIÇO}

O RadCom tem por finalidade o atendimento de determinada comunidade, com vistas a:

I - dar oportunidade à difusão de idéias, elementos de cultura, tradições e hábitos sociais da comunidade;

II - oferecer mecanismos à formação e integração da comunidade, estimulando o lazer, a cultura e o convívio social;

III - prestar serviços de utilidade pública, integrando-se aos serviços de defesa civil, sempre que necessário;

IV - contribuir para o aperfeiçoamento profissional nas áreas de atuação dos jornalistas e radialistas, de conformidade com a legislação profissional vigente;

V - permitir a capacitação dos cidadãos no exercício do direito de expressão, da forma mais acessível possível.

\section{CANAL DE OPERAÇÃO DAS ESTAÇÕES DO RADCOM}

5.1 A Agência Nacional de Telecomunicações - ANATEL designará um único e específico canal na faixa de freqüências do Serviço de Radiodifusão Sonora em Freqüência Modulada, para atender, em âmbito nacional, ao RadCom.

5.1.1 Em caso de manifesta impossibilidade técnica quanto ao uso desse canal em determinada região, a ANATEL indicará, em substituição, um único canal alternativo para utilização exclusiva nessa região, desde que haja algum que atenda aos critérios de proteção estabelecidos em norma.

5.1.1.1 Os canais a serem protegidos são os dos serviços de radiodifusão sonora em freqüência modulada e de radiodifusão de sons e imagens e retransmissão de televisão em VHF, previstos em plano básico de distribuição de canais, bem como os canais dos mesmos serviços localizados em Zona de Coordenação de país limítrofe que mantenha acordo ou convênio com o Brasil e, ainda, os canais dos Serviços de Radionavegação Aeronáutica e Móvel Aeronáutico.

\section{DE AUTORIZAÇÃO PARA EXECUÇÃO DO SERVIÇO}

6.1 Em localidades cuja área urbana estiver circunscrita a um círculo com raio menor ou igual a 3,5 km, somente será expedida uma autorização de RadCom.

6.2 São competentes para executar o RadCom fundações e associações comunitárias, 
sem fins lucrativos, desde que legalmente instituídas e devidamente registradas, sediadas na área da comunidade para a qual pretendem prestar o Serviço, e cujos dirigentes sejam brasileiros natos ou naturalizados há mais de dez anos.

6.2.1 A sede das fundações e associações de localidade enquadrada na situação indicada no item 6.1 poderá estar em qualquer ponto da área urbana.

6.3 Os dirigentes das entidades pretendentes à execução do Serviço, além das exigências deste item, deverão manter residência na área da comunidade atendida.

6.3.1 A residência dos dirigentes de entidades de localidades enquadradas na situação indicada no item 6.1 poderá estar em qualquer ponto da área urbana.

6.4. As entidades interessadas em executar o RadCom deverão encaminhar requerimento à Delegacia do Ministério das Comunicações na jurisdição onde será instalada a estação, conforme modelo próprio, indicando a área onde pretendem prestar o Serviço, informando o endereço pretendido para a instalação da antena, bem como as respectivas coordenadas geográficas com precisão de segundos.

6.5 A ANATEL verificará se a área de interesse faz parte da região de utilização do canal nacionalmente designado para o RadCom ou indicará um canal alternativo, conforme disposto no item 5 desta Norma.

6.6 Constatada a possibilidade técnica de que trata o item anterior, o Ministério das Comunicações publicará, no Diário Oficial da União, comunicado de inscrição para habilitação das entidades interessadas em prestar o Serviço na mesma área solicitada ou em área com o centro deslocado de até quinhentos metros daquela.

6.6.1 O comunicado de habilitação para inscrição de entidades interessadas estabelecerá um prazo de, no máximo, 45 dias para as inscrições, bem como informará o canal consignado para a estação, o endereço e as coordenadas geográficas inicialmente propostas para a instalação da antena e o valor e as condições de pagamento da taxa relativa às despesas de cadastramento.

6.7 As entidades interessadas na execução do RadCom, inclusive aquela cuja petição originou o comunicado de habilitação, deverão encaminhar à Delegacia do Ministério das Comunicações na jurisdição onde será instalada a estação, no prazo fixado, requerimento, acompanhado dos documentos a seguir indicados:

I - estatuto da entidade, devidamente registrado;

II - ata da constituição da entidade e eleição dos seus dirigentes, devidamente registrada;

III - prova de que seus diretores são brasileiros natos ou naturalizados há mais de dez anos e maiores de 21 anos ou emancipados;

IV - declaração assinada pelo representante legal da entidade de que todos os seus dirigentes residem na área da comunidade a ser atendida pela estação ou na área urbana da localidade, conforme o caso; 
V - declaração assinada por todos os diretores, comprometendo-se ao fiel cumprimento das normas estabelecidas para o Serviço;

VI - manifestação em apoio à iniciativa, formulada por entidades associativas e comunitárias, legalmente constituídas e sediadas na área pretendida para a prestação do Serviço ou, nos casos enquadrados no item 6.1, na área urbana da localidade, firmada por pessoas naturais ou jurídicas que tenham residência, domicílio ou sede nessas áreas, devidamente comprovada;

VII - comprovante de que obteve o assentimento prévio do órgão próprio, se a estação pretendida estiver situada na faixa de fronteira, conforme indicado no item 6.8;

VIII - declaração do representante legal de que a entidade não é prestadora de qualquer modalidade de serviço de radiodifusão, inclusive comunitária, ou de qualquer serviço de distribuição de sinais de televisão mediante assinatura, bem como de que a entidade não tem como integrante de seus quadros de sócios e de administradores pessoas que, nestas condições, participem de outra entidade detentora de outorga para execução de qualquer dos serviços mencionados;

IX - declaração do representante legal de que o local pretendido para a instalação do sistema irradiante possibilita o atendimento do disposto no item 14.2.7.1 ou 14.2.7.1.1;

X - planta de arruamento, em escala de denominador máximo igual a 10.000, onde deverá estar assinalado o local de instalação do sistema irradiante, com indicação das coordenadas geográficas com precisão de segundos, e traçada a circunferência de até um km de raio, que limita a área abrangida pelo contorno de serviço;

XI - declaração constando, se for o caso, sua denominação de fantasia.

6.8 Para obtenção do assentimento prévio de que trata o inciso VII do item 6.7, a interessada deverá enviar à Delegacia do Ministério das Comunicações na jurisdição onde será instalada a estação, requerimento dirigido ao Secretário de Assuntos Estratégicos da Presidência da República, solicitando o assentimento para instalar estação de radiodifusão comunitária na localidade pretendida, acompanhado da seguinte documentação:

I - minuta dos estatutos da entidade (se ainda em formação) ou cópia dos estatutos e suas alterações (se já constituída) em que constem artigos dispondo que:

a) a responsabilidade e a orientação intelectual da entidade caberão sempre a brasileiros natos ou naturalizados há mais de dez anos;

b) o quadro de pessoal será constituído de, ao menos, 2/3 (dois terços) de trabalhadores brasileiros;

c) a entidade não poderá efetuar nenhuma alteração do seu estatuto sem prévia autorização dos órgãos competentes;

II - prova de nacionalidade de todos os administradores (cópia da certidão de 
nascimento para os solteiros, cópia da certidão de casamento para os casados, cópia de certidão de casamento com a correspondente averbação para os desquitados ou separados judicialmente ou divorciados, e cópia da certidão de casamento e de óbito do cônjuge, para os viúvos);

III - prova de estarem em dia com as obrigações referentes ao serviço militar de todos os administradores;

IV - prova de estarem em dia com as obrigações relacionadas com a Justiça Eleitoral de todos os administradores.

6.9 Se apenas uma entidade se habilitar para a prestação do Serviço, estando regular a documentação apresentada, o Ministério das Comunicações expedirá autorização à referida entidade.

6.10 Havendo mais de uma entidade habilitada para a prestação do Serviço, o Ministério das Comunicações promoverá o entendimento entre elas, objetivando que se associem.

6.10.1 Será estabelecido um prazo de, no máximo, trinta dias para que as entidades habilitadas realizem o entendimento entre si e apresentem o resultado ao Ministério das Comunicações.

6.10.2 Não alcançando êxito, será realizada a escolha pelo critério de representatividade, evidenciada por meio de manifestações de apoio encaminhadas por membros ou por associações da comunidade a ser atendida, conforme mencionado no inciso VI do item 6.7.

6.10.3 Havendo igual representatividade entre as entidades, proceder-se-á a escolha por sorteio.

6.11 Selecionada a entidade a ser autorizada, a Secretaria de Serviços de Radiodifusão SSR estabelecerá um prazo de, no máximo, trinta dias para que esta apresente os dados de instalação da estação, conforme a seguir estabelecido:

I - formulário padronizado, devidamente preenchido, contendo as características técnicas de instalação e operação pretendidas para a estação do RadCom;

II - declaração firmada pelo representante legal da entidade de que:

a) na ocorrência de interferências prejudiciais causadas pela estação, interromperá imediatamente suas transmissões até que os problemas sejam sanados;

b)na ocorrência de interferências indesejáveis causadas pela estação, caso estas não sejam sanadas no prazo estipulado pela ANATEL, interromperá suas transmissões;

III - planta de arruamento, em escala de denominador máximo igual a 10.000, onde deverá estar assinalado o local de instalação do sistema irradiante, com indicação das coordenadas geográficas com precisão de segundos, e traçada a circunferência de até um km de raio, que limita a área abrangida pelo contorno de serviço; 
IV - diagrama de irradiação horizontal da antena transmissora, com a indicação do Norte Verdadeiro, diagrama de irradiação vertical e especificações técnicas do sistema irradiante proposto; no caso de antenas de polarização circular ou elíptica, devem ser apresentadas curvas distintas das componentes horizontal e vertical dos diagramas;

V - declaração do profissional habilitado de que a cota do terreno, no local de instalação do sistema irradiante, atende as condições exigidas no item 14.2.7.1 ou estudo específico, conforme determina o item 14.2.7.1.1;

VI - declaração do profissional habilitado atestando que a instalação proposta não fere os gabaritos de proteção aos aeródromos, ou declaração do órgão competente do Ministério da Aeronáutica autorizando a instalação proposta, ou, se for o caso, declaração de inexistência de aeródromos na localidade;

VII - parecer conclusivo, assinado pelo profissional habilitado, atestando que a instalação proposta atende a todas as exigências das normas técnicas em vigor aplicáveis à mesma e que o contorno de $91 \mathrm{dBm}$ da emissora não fica situado a mais de um km de distância da antena transmissora em nenhuma direção;

VIII - Anotação de Responsabilidade Técnica - ART referente à instalação proposta.

6.12 O formulário de que trata o item 6.11 estará disponível nas Delegacias do Ministério das Comunicações nos Estados.

6.13 Anteriormente à expedição da autorização, a SSR poderá formular exigências relativas às informações técnicas indicadas no item 6.11 .

6.14 Para a formalização da autorização, a entidade selecionada deverá encaminhar à SSR comprovante de recolhimento da taxa relativa às despesas de cadastramento.

\section{FORMALIZAÇÃO DA AUTORIZAÇÃO}

7.1 A autorização para execução do RadCom será formalizada mediante ato do Ministro das Comunicações que deverá conter, pelo menos, a denominação da entidade, o objeto e o prazo da autorização, a área de serviço da emissora, o endereço e as coordenadas geográficas de instalação da estação, a freqüência de operação e o prazo para início da execução do Serviço.

7.2 O Ministério das Comunicações providenciará a publicação, no Diário Oficial da União, do resumo do ato de autorização.

7.3 O ato de autorização somente produzirá efeitos legais após deliberação do Congresso Nacional, nos termos do parágrafo único do art. $2^{\circ}$ da Lei n. ${ }^{\circ}$ 9.612, de 1998, publicada em ato competente.

7.4 A autorização terá validade de três anos, permitida a renovação por igual período, se cumpridas as disposições previstas nesta Norma.

7.5 A cada entidade será expedida apenas uma autorização para execução do RadCom. 


\section{INSTALAÇÃO}

8.1 A instalação da estação deverá atender às disposições estabelecidas no item 14 desta Norma e deverá estar de acordo com os dados constantes dos formulários mencionados no inciso I do item 6.11.

8.1.1 Qualquer alteração na instalação da estação que implique modificação dos dados informados deverá ser submetida à prévia anuência da Delegacia do Ministério das Comunicações na jurisdição da estação, em formulário padronizado.

8.2 O prazo para o início efetivo da execução do RadCom é de seis meses a contar da data de vigência do ato de autorização, não podendo ser prorrogado.

\section{EXPEDIÇÃO DA LICENÇA PARA FUNCIONAMENTO DE ESTAÇÃO}

9.1 Dentro do prazo que lhe é concedido para iniciar a execução do Serviço e com a antecedência mínima de dez dias do seu termo final, a entidade autorizada deverá apresentar requerimento à Delegacia do Ministério das Comunicações na jurisdição da estação, solicitando expedição de Licença para Funcionamento de Estação, devendo instruir o requerimento com a informação relativa ao horário de funcionamento da estação e o comprovante de recolhimento da taxa de fiscalização da instalação.

9.2 Cumprida a formalidade estabelecida no item 9.1, a SSR emitirá a Licença para Funcionamento de Estação.

9.3 Caso a entidade tenha interesse em testar os equipamentos antes do início efetivo da execução do Serviço, uma vez concluída a instalação da estação, e dentro de tal prazo, poderá operar em caráter experimental, pelo período máximo de trinta dias, desde que comunique o fato à Delegacia do Ministério das Comunicações na jurisdição da estação, com antecedência mínima de cinco dias úteis.

9.4 Da Licença para Funcionamento de Estação deverá constar, pelo menos:

a) nome da entidade;

b) denominação de fantasia da emissora;

c) endereço do estúdio e da estação transmissora e coordenadas geográficas do sistema irradiante;

d) raio da área de serviço;

e) freqüência de operação;

f) indicativo de chamada;

g) fabricante, modelo e código de certificação do transmissor;

h) potência de operação do transmissor; 
i) fabricante, modelo, tipo, polarização, ganho e altura da antena transmissora com relação ao solo;

j) informação de que a emissora não tem direito a proteção contra interferências causadas por estações de telecomunicações e de radiodifusão regularmente instaladas. 9.5 Iniciada a operação da estação, a entidade autorizada comunicará o fato à ANATEL, no prazo máximo de cinco dias úteis, cabendo a esta proceder à vistoria a qualquer tempo.

9.6 Qualquer alteração na estação, que implique modificação nos dados constantes da Licença para Funcionamento de Estação, será objeto de emissão de nova Licença, uma vez comprovado o recolhimento da correspondente Taxa de Fiscalização da Instalação.

\section{EXECUÇÃO DO SERVIÇO}

10.1 A emissora do RadCom operará sem direito a proteção contra eventuais interferências causadas por estações de Serviços de Telecomunicações e de Radiodifusão regularmente instaladas.

10.2 Caso uma emissora do RadCom provoque interferência indesejável em Serviços de Telecomunicações e de Radiodifusão regularmente executados, a ANATEL

estabelecerá o prazo máximo de 48 horas para a eliminação da causa da interferência e, não sendo esta eliminada, determinará a interrupção do serviço da emissora interferente até que cesse a interferência.

10.3 Caso uma emissora do RadCom provoque interferência prejudicial em Serviços de Telecomunicações e de Radiodifusão regularmente executados, a ANATEL determinará a imediata interrupção do seu funcionamento, até a completa eliminação da causa da interferência.

10.4 A emissora de RadCom deverá manter a Licença para Funcionamento de Estação permanentemente exposta em local visível, no recinto onde se encontra o transmissor.

10.5 As emissoras do RadCom cumprirão período de oito horas, contínuas ou não, como tempo mínimo de operação diária.

10.5.1 Sempre que a entidade pretender alterar o horário de funcionamento de sua estação, deverá comunicar o fato ao Ministério das Comunicações com antecedência mínima de cinco dias úteis da data de efetivação da alteração.

10.6 Toda estação de RadCom é obrigada a irradiar seu indicativo de chamada a cada trinta minutos.

10.7 É vedada a formação de redes na execução do RadCom, excetuadas as situações de guerra, calamidade pública e epidemias, bem como as transmissões obrigatórias dos Poderes Executivo, Judiciário e Legislativo, definidas em lei.

10.8 A entidade autorizada a executar o RadCom não poderá estabelecer ou manter vínculos que a subordinem ou a sujeitem à gerência, à administração, ao domínio, ao 
comando ou à orientação de qualquer outra entidade, mediante compromissos ou relações financeiras, religiosas, familiares, político-partidárias ou comerciais.

10.9 Os dirigentes das executantes do RadCom deverão manter residência na área da comunidade atendida ou, nos casos enquadrados no item 6.1, na área urbana da localidade.

10.9.1 A entidade autorizada a executar o RadCom deverá manter disponível e atualizado o nome e o endereço residencial de cada um de seus dirigentes, para qualquer solicitação ou inspeção do Ministério das Comunicações.

10.10 Toda a programação deverá ser gravada e mantida em arquivo durante as 24 horas subseqüentes ao encerramento dos trabalhos diários da emissora, devendo também ser conservados em arquivo os textos dos programas, inclusive noticiosos, devidamente autenticados pelos responsáveis, durante sessenta dias.

\section{PROGRAMAÇÃO}

11.1 As emissoras do RadCom atenderão, em sua programação, aos seguintes princípios:

1. deverá ser dada preferência a finalidades educativas, artísticas, culturais e informativas, em benefício do desenvolvimento geral da comunidade;

2. deverá haver promoção das atividades artísticas e jornalísticas, e da integração dos membros da comunidade atendida;

3. deverão ser respeitados os valores éticos e sociais da pessoa e da família, favorecendo a integração dos membros da comunidade atendida;

4. não deverá haver discriminação de raça, religião, sexo, preferências sexuais, convicções político-ideológico-partidárias e condição social;

5. é vedado o proselitismo de qualquer natureza na programação das emissoras de radiodifusão comunitária;

6. as programações opinativa e informativa observarão os princípios da pluralidade de opinião e de versão simultâneas em matérias polêmicas, divulgando sempre as diferentes interpretações relativas aos fatos noticiados;

7. qualquer cidadão da comunidade beneficiada terá direito a emitir opiniões sobre quaisquer assuntos abordados na programação da emissora, bem como manifestar idéias, propostas, sugestões, reclamações ou reivindicações, devendo observar apenas o momento adequado da programação para fazê-lo, mediante pedido encaminhado à direção da entidade.

11.2 A entidade autorizada a executar o RadCom deverá instituir um Conselho Comunitário, composto por, no mínimo, cinco pessoas representantes de entidades da comunidade local ou, nos casos enquadrados no item 6.1, da área urbana da localidade, tais como associações de classe, beneméritas, religiosas ou de moradores, desde que legalmente instituídas, com o objetivo de acompanhar a programação da emissora, com vistas ao atendimento do interesse exclusivo da comunidade e dos princípios estabelecidos no art. $4^{\circ}$ da Lei ${ }^{\circ}$ 9.612, de 1998.

11.2.1 A entidade deverá manter disponível e atualizado, para qualquer solicitação ou inspeção do Ministério das Comunicações, o ato que estabeleceu a composição do 
Conselho Comunitário.

11.3 As emissoras do RadCom assegurarão, em sua programação, espaço para divulgação de planos e realizações de entidades ligadas, por suas finalidades, ao desenvolvimento da comunidade.

11.4 As autorizadas do RadCom poderão admitir patrocínio, sob a forma de apoio cultural, para os programas a serem transmitidos, desde que restritos aos estabelecimentos situados na área da comunidade atendida ou, nos casos enquadrados no item 6.1, na área urbana da localidade.

11.5 É vedada a cessão ou arrendamento da emissora do RadCom ou de horários de sua programação.

\section{TRANSFERÊNCIA DA AUTORIZAÇÃO}

12.1 É vedada a transferência da autorização para execução do RadCom, a qualquer título, nos termos do art. 12 da Lei n. ${ }^{\circ}$ 9.612, de 1998.

12.2 A entidade autorizada a executar o RadCom pode, sem a anuência do Ministério das Comunicações, ressalvado o disposto na alínea c do inciso I do item 6.8, realizar alterações em seus atos constitutivos e modificar a composição de sua diretoria, desde que essas operações não impliquem alteração nos termos e condições inicialmente exigidos para a autorização, devendo esta apresentar à SSR os atos que caracterizam as alterações mencionadas, devidamente registrados ou averbados na repartição competente, para fins de registro e controle, no prazo de trinta dias contado de sua efetivação.

\section{RENOVAÇÃO DA AUTORIZAÇÃO}

13.1 A autorização para execução do RadCom poderá ser renovada por um outro período de três anos, desde que a autorizada apresente solicitação neste sentido com antecedência de três meses a um mês do seu termo final e que cumpra as exigências estabelecidas para tanto pelo Ministério das Comunicações.

13.2 A renovação da autorização para execução do RadCom implicará pagamento de valor relativo às despesas decorrentes desse ato.

\section{ASPECTOS TÉCNICOS}

\subsection{CARACTERÍSTICAS DA EMISSÃO}

\subsubsection{Designação: monofônica: 180KF3EGN estereofônica: 256KF8EHF}

14.1.2 Polarização: a polarização da onda eletromagnética emitida pela antena poderá ser linear (horizontal ou vertical), circular ou elíptica.

14.1.3 Tolerância de freqüência: a freqüência central da emissão não deve se afastar mais que $2000 \mathrm{~Hz}$ (para cima ou para baixo) de seu valor nominal. 
14.1.4 Espúrios de radiofreqüência: qualquer emissão presente em freqüências afastadas de 120 a $240 \mathrm{kHz}$, inclusive, da freqüência da portadora deverá estar pelo menos 25 dB abaixo do nível da portadora sem modulação; as emissões em freqüências afastadas de mais de $240 \mathrm{kHz}$ até $600 \mathrm{kHz}$, inclusive, da freqüência da portadora deverão estar pelo menos $35 \mathrm{~dB}$ abaixo do nível da portadora sem modulação; as emissões em freqüências afastadas de mais de $600 \mathrm{kHz}$ da freqüência da portadora deverão estar pelo menos $(73+\mathrm{P}) \mathrm{dB}(\mathrm{P}=$ potência de operação do transmissor, em dBk) abaixo do nível da portadora sem modulação.

14.1.5 É estabelecida a referência de 75 kHz no desvio de freqüência da portadora para definir o nível de modulação de 100\%.

\subsection{CARACTERÍSTICAS DAS EMISSORAS}

14.2.1 A potência efetiva irradiada - ERP por emissora do RadCom será, no máximo, 25 Watts.

14.2.2 O máximo valor de intensidade de campo que a estação poderá ter a uma distância de $1 \mathrm{~km}$ da antena e a uma altura de 10 metros sobre o solo será de $91 \mathrm{dBm}$, obtido a partir da expressão:

$\mathrm{E}(\mathrm{dBm})=107+\mathrm{ERP}(\mathrm{dBk})-20 \log \mathrm{d}(\mathrm{km})$, Onde:

ERP (dBk) - potência efetiva irradiada, em dB relativos a $1 \mathrm{~kW}$ (tomado o valor máximo, de -16 dBk, correspondentes a $25 \mathrm{~W}$ ), sendo:

ERP $(\mathrm{dBk})=10 \log ($ Pt $x$ Ght $x$ Gvt $x$ h $)$, em que:

Pt - potência do transmissor, em kW

Ght - ganho da antena, no plano horizontal, em relação ao dipolo de meia onda, em vezes

Gvt - ganho da antena, no plano vertical, em relação ao dipolo de meia onda, em vezes

h - eficiência da linha de transmissão

d - distância da antena transmissora ao limite da área de serviço, em km, (tomado o valor máximo de um km)

0. Em nenhuma direção, o valor da intensidade de campo, a um km, poderá ser superior à indicada no item 14.2.2.

14.2.3 A área de serviço de uma emissora do RadCom é aquela limitada por uma circunferência de raio igual ou inferior a mil metros a partir da antena transmissora, e será estabelecida de acordo com a área da comunidade servida pela estação.

14.2.4 O sistema irradiante de estação do RadCom deverá estar localizado no centro da área de serviço da emissora. 
14.2.5 O diagrama de irradiação da antena utilizada por estação do RadCom deverá ser onidirecional.

14.2.6 O ganho da antena transmissora será de, no máximo, $0 \mathrm{~dB}$, em relação ao dipolo de meia onda.

14.2.7 A altura da antena com relação ao solo será de, no máximo, trinta metros.

14.2.7.1 A cota do terreno (solo), no local de instalação do sistema irradiante, não poderá ter desnível maior que trinta metros, com relação à cota de qualquer ponto do terreno no raio de um km em torno do local do sistema irradiante.

14.2.7.1.1 Caso a condição estabelecida no item 14.2.7.1 não seja satisfeita, a instalação proposta será analisada como situação especial, mediante análise, caso a caso, de estudo específico que apresente as peculiaridades do terreno, com levantamento das cotas num raio de até $3,5 \mathrm{~km}$, e no qual fique demonstrada a adequada prestação de serviço na área a ser atendida, sem acréscimo dos valores de intensidade de campo sobre áreas de serviço de estações de radiodifusão comunitária ocupando o mesmo canal. 14.2.8 A ligação entre o transmissor e a antena deve ser feita por meio de cabo coaxial.

14.2.9 O estúdio e o transmissor devem estar instalados, preferencialmente, na mesma edificação, não sendo permitida a instalação de estúdio auxiliar.

14.2.9.1 No caso em que o estúdio e o transmissor não estejam instalados na mesma edificação, não será autorizado o uso de freqüências destinadas aos serviços auxiliares de radiodifusão e correlatos.

14.2.10 A separação mínima entre duas estações do RadCom será de 3,5km.

\subsection{TRANSMISSORES}

14.3.1 Somente será permitida a utilização de equipamentos transmissores certificados pela ANATEL.

14.3.1.1 Os equipamentos transmissores utilizados no RadCom deverão ser présintonizados na freqüência de operação consignada à emissora e deverão ter sua potência de saída inibida à potência de operação constante da Licença para Funcionamento de Estação.

\subsection{REQUISITOS MÍNIMOS DOS TRANSMISSORES}

As especificações dos transmissores deverão atender os requisitos mínimos a seguir indicados.

14.4.1 Os transmissores não poderão ter dispositivos externos que permitam a alteração da freqüência de operação.

14.4.2 Os transmissores não poderão ter dispositivos externos que permitam a alteração da potência de operação. 
14.4.3 Os transmissores devem estar completamente encerrados em gabinete metálico e todas as partes expostas ao contato dos operadores serão eletricamente interligadas e conectadas à terra.

14.4.4 Todo o transmissor deve ter fixada no gabinete uma placa de identificação onde conste, no mínimo, o nome do fabricante, o número de série, a potência nominal e a freqüência de operação.

14.4.5 O dispositivo de controle da freqüência deve ser tal que permita a manutenção automática da freqüência de operação entre os limites de mais ou menos $2000 \mathrm{~Hz}$ da freqüência nominal.

14.4.6 Qualquer emissão presente em freqüências afastadas de 120 a $240 \mathrm{kHz}$ (inclusive) da freqüência da portadora deverá estar, pelo menos, 25 dB abaixo do nível da portadora sem modulação.

14.4.7 As emissões em freqüências afastadas da freqüência da portadora de $240 \mathrm{kHz}$ até $600 \mathrm{kHz}$, inclusive, deverão estar, pelo menos, 35 dB abaixo do nível da portadora sem modulação.

14.4.8 As emissões em freqüências afastadas de mais de $600 \mathrm{kHz}$ da freqüência da portadora deverão estar abaixo do nível da portadora sem modulação de $(73+\mathrm{P}) \mathrm{dB}$, onde P é a potência de operação do transmissor em dBk.

14.4.9 A distorção harmônica total das freqüências de áudio, introduzidas pelo transmissor, não deve ultrapassar o valor eficaz de 3,0\% na faixa de 50 a $15.000 \mathrm{~Hz}$ para percentagens de modulação de 25, 50 e $100 \%$.

14.4.10 O nível de ruído, por modulação em freqüência, medido na saída do transmissor, na faixa de 50 a $15.000 \mathrm{~Hz}$, deverá estar, pelo menos, $50 \mathrm{~dB}$ abaixo do nível correspondente a $100 \%$ de modulação da portadora por um sinal senoidal de 400 Hz.

14.4.11 O nível de ruído, por modulação em amplitude, medido na saída do transmissor, na faixa de 50 a $15.000 \mathrm{~Hz}$, deverá estar, pelo menos, $50 \mathrm{~dB}$ abaixo do nível que represente $100 \%$ de modulação em amplitude.

\section{INFRAÇÕES E PENALIDADES}

15.1 As penalidades aplicáveis em razão de infringência a qualquer dispositivo da Lei n. ${ }^{\circ}$ 9.612, de 1998, de seu Regulamento, desta Norma e das demais normas aplicáveis ao RadCom são:

I - advertência;

II - multa; e

III - na reincidência, revogação da autorização. 
15.1.1 A pena de advertência poderá ser aplicada ao infrator primário quando incorrer em infração considerada de menor gravidade.

15.1.2 Os valores das multas a serem aplicadas obedecerão aos critérios estabelecidos no art. 59 da Lei n. ${ }^{\circ} 4.117$, de 1962, com a redação que lhe foi dada pelo art. $3^{\circ}$ do Decreto-lei n. ${ }^{\circ}$ 236, de 1967

15.2 Antes da aplicação de penalidades, a autorizada será notificada para exercer seu direito de defesa, conforme o estabelecido na Lei no 4.117, de1962, sem prejuízo da apreensão cautelar de que trata o parágrafo único do seu art. 70, com a redação que lhe foi dada pelo art. $3^{\circ}$ do Decreto-lei n ${ }^{\circ}$ 236, de 1967.

15.3 São puníveis com multa as seguintes infrações na operação das emissoras do RadCom:

I - transferência a terceiros dos direitos ou procedimentos de execução do Serviço;

II - permanência fora de operação por mais de trinta dias sem motivo justificável;

III - uso de equipamentos não certificados pela ANATEL;

IV - manutenção pela autorizada, no seu quadro diretivo, de dirigente com residência fora da área da comunidade atendida ou, nos casos enquadrados no item 6.1, da área urbana da localidade;

V - não manutenção do Conselho Comunitário, nos termos da Lei;

VI - estabelecimento ou manutenção de vínculos que subordinem a entidade ou a sujeitem à gerência, à administração, ao domínio, ao comando ou à orientação de qualquer outra entidade, mediante compromissos ou relações financeiras, religiosas, familiares, político-partidárias ou comerciais;

VII - não comunicação ao Ministério das Comunicações, no prazo de trinta dias, das alterações efetivadas nos atos constitutivos ou da mudança de sua diretoria;

VIII - modificação dos termos e das condições inicialmente atendidos para a expedição do ato de autorização;

IX - não destinação de espaço na programação disponível à divulgação de planos e realizações de entidades ligadas, por suas finalidades, ao desenvolvimento da comunidade;

X - formação de redes na exploração do RadCom;

XI - não integração a redes quando convocadas em situações de guerra, calamidade pública e epidemias;

XII - não integração a redes para as transmissões obrigatórias dos Poderes Executivo, Judiciário e Legislativo; 
XIII - cessão ou arrendamento da emissora ou de horários de sua programação;

XIV - transmissão de patrocínio em desacordo com as normas legais pertinentes ;

XV - transmissão de propaganda ou publicidade comercial a qualquer título;

XVI - desvirtuamento das finalidades do RadCom e dos princípios fundamentais da programação;

XVII - utilização de denominação de fantasia diversa da comunicada ao Ministério das Comunicações;

XVIII - imposição de dificuldades à fiscalização do Serviço;

XIX - não manutenção em dia dos registros da programação em texto e fitas, nos termos da regulamentação;

XX - uso de equipamentos fora das especificações constantes dos certificados emitidos pela ANATEL;

XXI - não obediência ao tempo de funcionamento da estação comunicado ao Ministério das Comunicações;

XXII - alteração das características constantes da Licença para Funcionamento de Estação, sem observância às formalidades estabelecidas;

XXIII - não solicitação, no prazo estabelecido, da expedição de Licença para Funcionamento de Estação;

XXIV - não observância do prazo estabelecido para início da execução do Serviço;

XXV - utilização de freqüência diversa da autorizada;

XXVI - início da execução do Serviço sem estar previamente licenciada;

XXVII - início da operação em caráter experimental sem ter comunicado o fato no prazo estabelecido em norma complementar;

XXVIII - não comunicação de alteração do horário de funcionamento;

XXIX - não cumprimento, no tempo estipulado, de exigência que lhe tenha sido feita pelo Ministério das Comunicações ou pela ANATEL.

\section{INTERRUPÇÃO DO SERVIÇO}

16.1 A execução do RadCom será interrompida nos seguintes casos:

I - de imediato, na ocorrência de interferências prejudiciais;

II - no prazo estipulado pela ANATEL, na constatação de interferências indesejáveis, 
caso estas não tenham sido eliminadas;

III - quando for criada situação de perigo de vida.

\section{DISPOSIÇÃO GERAL}

As entidades autorizadas a executar o RadCom estão sujeitas ao pagamento das taxas de fiscalização das telecomunicações previstas em lei. 


\section{ANEXO D - Norma Complementar $n^{\circ}$ $1 / 2004$}

\section{OBJETIVO}

Esta Norma tem por objetivo complementar as disposições relativas ao Serviço de Radiodifusão Comunitária, instituído pela Lei n. ${ }^{\circ}$ 9.612, de 19 de fevereiro de 1998, como um serviço de radiodifusão sonora, em freqüência modulada, com baixa potência e cobertura restrita, para ser outorgado a fundações e associações comunitárias, sem fins lucrativos, sediadas na localidade de execução do Serviço, e estabelecer as condições técnicas de operação das respectivas estações.

\section{REFERÊNCIAS BÁSICAS}

\subsection{Constituição Federal.}

2.2. Código Brasileiro de Telecomunicações, instituído pela Lei n. ${ }^{\circ}$ 4.117, de 27 de agosto de 1962, modificado e complementado pelo Decreto-lei n. ${ }^{\circ} 236$, de 28 de fevereiro de 1967.

2.3. Lei n. ${ }^{\circ}$ 9.612, de 19 de fevereiro de 1998, que institui o Serviço de Radiodifusão Comunitária.

2.4. Lei $\mathrm{n}^{\circ} 10.610$, de 12.12 .2002 , que altera o prazo de outorga de três para dez anos.

2.5. Medida Provisória $n^{\circ}$ 2.216-37, de 31.08.01, art. 19, que altera o parágrafo único do art. $2^{\circ}$ da Lei 9.612, de 19 de fevereiro de 1998, criando a possibilidade de emissão de autorização provisória para o funcionamento de estação do serviço de radiodifusão comunitária.

2.6. Regulamento dos Serviços de Radiodifusão, aprovado pelo Decreto n. ${ }^{\circ}$ 52.795, de 31 de outubro de 1963, e suas alterações.

2.7. Regulamento do Serviço de Radiodifusão Comunitária, aprovado pelo Decreto n. $^{\circ}$ 2.615, de 3 de junho de 1998.

2.8. Regulamento Técnico para Emissoras de Radiodifusão Sonora em Freqüência Modulada, aprovado pela Resolução Anatel n 67, de 12 de novembro de 1998.

2.9. Resolução Anatel no 60, de 24 de setembro de 1998, que designou o canal 200 para uso exclusivo e em caráter secundário, das estações do Serviço de Radiodifusão Comunitária, em nível nacional.

2.10. Plano de Referência para a Distribuição de Canais do Serviço de Radiodifusão Comunitária (PRRadCom), da Anatel. 


\section{DA MANIFESTAÇÃO DE INTERESSE EM EXECUTAR O SERVIÇO}

3.1. A entidade interessada em executar o Serviço de Radiodifusão Comunitária deverá, por intermédio de seu representante legal, dirigir requerimento ao Ministro de Estado das Comunicações, demonstrando o seu interesse, bem como solicitando a designação de canal de operação.

3.1.1. O requerimento deverá ser feito mediante a utilização do formulário padronizado Modelo A-1, e poderá ser enviado por meio eletrônico, pela Internet, no endereço www.mc.gov.br, ou apresentado diretamente ao Ministério das Comunicações, em Brasília, ou ainda encaminhado via postal, por correspondência dirigida à Secretaria de Serviços de Comunicação Eletrônica.

3.1.2. No requerimento Modelo A-1 deverão ser informados os seguintes dados:

a) a denominação da entidade;

b) o número de inscrição da entidade no Cadastro Nacional de Pessoas Jurídicas do Ministério da Fazenda - CNPJ/MF;

c) o endereço da sede da entidade;

d) o $\mathrm{n}^{\circ}$ do telefone e o endereço eletrônico, se houver;

e) o endereço pretendido para a instalação do sistema irradiante, bem como as respectivas

coordenadas geográficas na forma GGMM’SS (GPS - SAD 69 ou WGS84);

f) o local e a data ;

g) a assinatura do representante legal ;

h) o nome do representante legal ;

i) o número de inscrição do responsável legal no Cadastro de Pessoas Físicas (CPF);

j) o endereço para correspondência e o telefone para contato.

3.2. O Ministério das Comunicações analisará o requerimento, concluindo pelo seu prosseguimento, sobrestamento ou arquivamento.

3.2.1. A decisão pelo prosseguimento do requerimento poderá, considerado o interesse público, resultar na publicação de Aviso de Habilitação.

3.2.2. O requerimento ficará sobrestado quando existir, em análise no Ministério, pedido de autorização para a execução do Serviço na mesma área de interesse, devendo assim permanecer até a decisão do pedido em tramitação.

3.2.3. O requerimento será arquivado quando:

a) existir entidade autorizada na área de execução de serviço pretendida;

b) a distância entre os sistemas irradiantes da estação autorizada e da estação pretendida for inferior a quatro quilômetros; ou

c) não houver canal designado para o município no Plano de Referência para a

Distribuição de Canais do Serviço de Radiodifusão Comunitária (PRRadCom), da

Anatel.

3.2.4. O arquivamento ou sobrestamento do processo, bem como as razões que determinaram a decisão, deverão ser comunicados à entidade requerente, por meio de ofício expedido pela Secretaria de Serviços de Comunicação Eletrônica. 


\section{DOS CANAIS DE OPERAÇÃO DAS ESTAÇÕES}

4.1. Havendo na localidade pretendida manifesta impossibilidade técnica quanto ao uso do canal 200, designado, nos termos da Resolução n ${ }^{\circ}$ 60, de 24 de setembro de 2003, para atender, em âmbito nacional, ao Serviço de Radiodifusão Comunitária, a Anatel indicará, em substituição, canal alternativo para utilização exclusiva naquela localidade, desde que exista canal que atenda aos critérios de proteção estabelecidos nesta Norma Complementar, relativos à compatibilidade eletromagnética entre estações envolvidas na análise.

4.1.1. Os canais a serem protegidos são os dos serviços de radiodifusão sonora em freqüência modulada, de radiodifusão de sons e imagens e de retransmissão de televisão em VHF, previstos em Planos Básicos de Distribuição de Canais, bem como os canais dos mesmos serviços localizados em Zona de Coordenação de país limítrofe que mantenha acordo ou convênio com o Brasil e, ainda, as estações dos serviços de radionavegação aeronáutica e móvel aeronáutico.

4.2. A Anatel promoverá, paulatinamente, a substituição dos canais alternativos atualmente constantes do PRRadCom pelos canais 200 (87,9 MHz), 199 (87,7 MHz) e 198 (87,5 MHz).

\section{DO AVISO DE HABILITAÇÃO}

5.1. Existindo canal designado pela Anatel para a execução do Serviço em determinada localidade, o Ministério das Comunicações publicará Aviso de Habilitação no Diário Oficial da União e o veiculará na Internet, no endereço www.mc.gov.br, garantindo ampla divulgação, convocando as entidades interessadas em executar o Serviço de Radiodifusão Comunitária a apresentarem a documentação exigida no item 7 para o procedimento seletivo.

5.2 . Do Aviso de Habilitação deverá constar:

a) o Estado e o município;

b) as coordenadas geográficas propostas para instalação do sistema irradiante;

c) o canal de operação consignado;

d) o prazo de quarenta e cinco dias para a apresentação da documentação;

e) a relação da documentação a ser apresentada pelas entidades interessadas;

f) o valor da taxa relativa às despesas de cadastramento, bem como o banco, a agência e a conta na qual deverá ser efetuado o depósito; e

g) determinação de que poderão se habilitar todas as entidades cujo local pretendido para a instalação do sistema irradiante esteja circunscrito a um raio de até um quilômetro das coordenadas geográficas constantes do Aviso.

5.3. Somente será publicado Aviso de Habilitação para localidade onde não haja, em tramitação, outro Aviso de Habilitação para execução do Serviço de Radiodifusão Comunitária.

5.4. Concluído o prazo previsto no Aviso de Habilitação, o Ministério das Comunicações publicará no Diário Oficial da União e disponibilizará na Internet relação nominal das entidades que solicitaram autorização para execução do Serviço de Radiodifusão Comunitária, em cada localidade, organizada por Unidade da Federação. 


\section{DO REQUERIMENTO PARA AUTORIZAÇÃO}

6.1 A entidade interessada em obter a autorização para executar o Serviço de Radiodifusão Comunitária deverá apresentar requerimento padronizado, Modelo A-2, e a documentação relacionada no subitem 7.1 e detalhada no subitem 7.2.

6.2. No requerimento padronizado, Modelo A-2, deverá ser informado:

a) os dados da entidade;

b) a relação da documentação que está sendo apresentada ao Ministério das Comunicações; e

c) o número de manifestações de apoio que estão sendo apresentadas pela entidade, conforme constante do subitem 7.2.4.

6.3. O requerimento padronizado, Modelo A-2, poderá ser:

a) enviado pela Internet, no endereço www.mc.gov.br;

b) encaminhado via postal, por meio de correspondência dirigida à Secretaria de Serviços de Comunicação Eletrônica do Ministério das Comunicações, em Brasília; ou c) entregue diretamente no protocolo central do Ministério das Comunicações, em Brasília.

6.3.1. No caso de o requerimento ser formulado via Internet, concluído o preenchimento, o Sistema de Informações do Serviço de Radiodifusão Comunitária, denominado Sistema RadCom, solicitará a conferência e a confirmação ou retificação dos dados informados.

6.3.1.1. Confirmados os dados, a entidade enviará o requerimento pela Internet e receberá, imediatamente, por meio eletrônico, a certificação do recebimento e o número de protocolo a ser atribuído ao respectivo processo.

6.3.1.2. A documentação referente ao requerimento enviado pela Internet, bem como as correspondentes manifestações de apoio, poderão ser entregues pessoalmente no protocolo central do Ministério das Comunicações ou encaminhadas à Secretaria de Serviços de Comunicação Eletrônica, por via postal, indicando, na parte externa do envelope, o nome da entidade e o número de protocolo atribuído ao processo pelo Sistema RadCom.

6.3.2. Caso o requerimento padronizado, Modelo A-2, seja encaminhado via postal, ou entregue diretamente no protocolo central do Ministério das Comunicações, deverá ser acompanhado pela documentação referente aos dados nele informados e das correspondentes manifestações de apoio.

6.3.2.1. Ao receber o envelope contendo o requerimento e a documentação, a Secretaria de Serviços de Comunicações Eletrônica providenciará a inserção dos dados da entidade no Sistema RadCom e informará o recebimento da documentação e o número do processo.

\section{DA DOCUMENTAÇÃO A SER APRESENTADA}

7.1. A entidade requerente deverá apresentar a seguinte documentação: 
a) cópia de comprovante de inscrição no Cadastro Nacional de Pessoas Jurídicas do Ministério da Fazenda - CNPJ/MF;

b) Estatuto Social, devidamente registrado;

c) Ata de constituição da entidade e Ata de eleição da diretoria em exercício, devidamente registradas;

d) relação contendo o nome de todos os associados pessoas naturais, com o número do

$\mathrm{CPF}$, número do documento de identidade e órgão expedidor e endereço de residência

ou domicílio, bem como de todos os associados pessoas jurídicas, com o número do

CNPJ, número de registro no órgão competente e endereço da sede;

e) prova de que seus diretores são brasileiros natos ou naturalizados há mais de dez anos e maiores de dezoito anos ou emancipados;

f) manifestação de apoio à iniciativa, formulada por pessoas jurídicas legalmente constituídas e sediadas na área pretendida para a execução do Serviço ou na área urbana da localidade, conforme o caso, ou firmada por pessoas naturais que tenham residência ou domicílio nessa área;

g) declaração, assinada pelo representante legal, especificando o endereço completo da sede da entidade;

h) declaração, assinada pelo representante legal, de que todos os seus dirigentes residem na área da comunidade a ser atendida pela estação ou na área urbana da localidade, conforme o caso;

i) declaração, assinada por todos os diretores, comprometendo-se ao fiel cumprimento das normas estabelecidas para o Serviço;

j) declaração, assinada pelo representante legal, de que a entidade não é executante de qualquer modalidade de serviço de radiodifusão, inclusive comunitária, ou de qualquer serviço de distribuição de sinais de televisão mediante assinatura, bem como de que a entidade não tem como integrante de seu quadro diretivo ou de associados, pessoas que, nessas condições, participem de outra entidade detentora de outorga para execução de qualquer dos serviços mencionados;

l) declaração, assinada pelo representante legal, constando a denominação de fantasia da emissora, se houver;

m) declaração, assinada pelo representante legal, de que o local pretendido para a instalação do sistema irradiante possibilita o atendimento do disposto no subitem 18.2.7.1 ou 18.2.7.1.1;

n) declaração, assinada por profissional habilitado ou pelo representante legal da entidade, confirmando as coordenadas geográficas, na padronização GPS-SAD69 ou WGS84, e o endereço proposto para instalação do sistema irradiante;

o) declaração, assinada pelo representante legal, de que a entidade apresentará Projeto Técnico, de acordo com as disposições desta Norma Complementar, e com os dados indicados em seu requerimento, caso lhe seja outorgada a autorização; e

p) comprovante de recolhimento da taxa relativa às despesas de cadastramento.

7.2. A documentação apresentada pelas entidades deverá atender os requisitos estabelecidos nos subitens 7.2.1 a 7.2.4 e 7.3.

7.2.1. O Estatuto Social das associações comunitárias e fundações deverá:

a) ser apresentado na íntegra;

b) estar legível;

c) conter no cabeçalho e artigos pertinentes, a denominação da entidade rigorosamente de acordo com a constante da Ata de constituição ou da Ata da Assembléia Geral que a tenha 
alterado, quando se tratar de Associação Comunitária, ou ainda, do ato constitutivo ou da alteração estatutária que a tenha alterado, quando se tratar de Fundação;

d) estar registrado no Livro "A" do Registro de Pessoas Jurídicas, sendo que qualquer alteração efetuada deverá estar averbada junto àquele Registro;

e) conter a denominação, os fins, o endereço da sede e o tempo de duração da entidade e, ainda, quando houver, o fundo social;

f) indicar, entre seus objetivos sociais, a finalidade específica de executar o Serviço de Radiodifusão Comunitária, mencionando expressamente os fins a que se destina, conforme incisos I a V do art. 3o da Lei no 9.612, de 1998;

g) indicar o modo de constituição e funcionamento dos órgãos deliberativos e administrativos da entidade, estabelecendo:

g.1) os cargos que compõem a estrutura deliberativa e administrativa, bem como as suas respectivas atribuições;

g.2) o cargo ao qual caberá a representação passiva e ativa, judicial e extrajudicial;

g.3) o tempo de mandato dos membros que compõem a diretoria;

h) indicar que todos os dirigentes sejam brasileiros natos ou naturalizados há mais de dez anos;

i) indicar que todos os dirigentes deverão manter residência na área da comunidade atendida;

j) indicar as condições para a alteração das disposições estatutárias, observadas as disposições contidas nos arts. 59 e 67 da Lei n o 10.406, de 10 de janeiro de 2002, que institui o Código Civil; e

l) indicar as condições de extinção da entidade e a previsão da destinação do seu patrimônio, observadas as disposições contidas nos arts. 61 e 69 da Lei n o 10.406, de 10 de janeiro de 2002, que institui o Código Civil.

7.2.1.1. Os Estatutos Sociais das associações comunitárias deverão ainda conter disposições que:

a) estabeleçam os critérios para ingresso, demissão e exclusão dos associados;

b) assegurem o ingresso, como associado, de todo e qualquer cidadão domiciliado na localidade;

c) assegurem a todos os seus associados, pessoas físicas, o direito de votar e ser votado para todos os cargos que compõem os órgãos administrativos e deliberativos, bem como o direito de voz e voto nas deliberações sobre a vida social da entidade, nas instâncias deliberativas existentes;

d) assegurem o ingresso, como associadas, de pessoas jurídicas sem fins lucrativos, sediadas na localidade, conferindo-lhes inclusive, por intermédio de seus representantes legais, o direito de escolher, mediante voto, os integrantes dos órgãos deliberativos e administrativos, bem como o direito de voz e voto nas deliberações sobre a vida social da entidade, nas instâncias deliberativas existentes;

e) estabeleçam os direitos e deveres dos associados;

f) especifiquem as fontes de recursos para manutenção da entidade;

g) determinem que não haverá a distribuição de bônus ou eventuais sobras da receita entre os associados; e

h) determinem as competências da Assembléia Geral, observadas as disposições constantes do art. 59 da Lei no 10.406, de 10 de janeiro de 2002, que institui o Código Civil.

7.2.2. A Ata de constituição da entidade e Ata de eleição da diretoria deverão:

a) ser apresentadas na íntegra; e 
b) estar legíveis.

7.2.2.1. A Ata de constituição da entidade deverá ser registrada no Livro “A” do Registro Civil de Pessoas Jurídicas e a Ata de eleição de diretoria deverá ser registrada no Livro “B” do Registro de Títulos e Documentos.

7.2.3. A comprovação de nacionalidade e da capacidade civil dos dirigentes poderá ser feita mediante a apresentação de um dos seguintes documentos:

a) certidão de nascimento ou casamento;

b) certificado de reservista;

c) título de eleitor;

d) carteira profissional;

e) cédula de identidade;

f) certificado de naturalização expedido há mais de dez anos; ou

g) escritura pública de emancipação.

7.2.3.1. Não serão aceitos, a título de comprovação de maioridade e de nacionalidade, a carteira nacional de habilitação $(\mathrm{CNH})$ e a inscrição no Cadastro de Pessoas Físicas (CPF).

7.2.4. As manifestações de apoio:

a) quando individual, deverão conter o nome, o número da identidade, o endereço do domicílio ou residência, o Código de Endereçamento Postal (CEP) e a assinatura do declarante;

b) quando coletiva, apresentadas sob a forma de abaixo-assinado, deverão conter o nome, o número da identidade, o endereço do domicílio ou residência, o Código de Endereçamento Postal (CEP) e a assinatura de cada declarante;

c) quando apresentadas por pessoas jurídicas, facultada a entidades associativas e comunitárias, legalmente constituídas e sediadas na área pretendida para a execução do Serviço, deverão conter a denominação da entidade apoiadora, o endereço da sede, o Código de Endereçamento Postal (CEP) e a assinatura do representante legal, bem como ser acompanhada de cópia autenticada do comprovante de inscrição no Cadastro Nacional de Pessoas Jurídicas e da Ata de Eleição ou do Termo de Posse do declarante; d) quando apresentadas por associados da entidade requerente, deverão ser comprovadas por meio de assinaturas constantes da Ata de Assembléia Geral, convocada especialmente para manifestar apoio à iniciativa de requerer a autorização para execução do Serviço de Radiodifusão Comunitária;

d.1) a Ata deverá conter, ainda, o nome, o número da identidade, o endereço do domicílio ou residência e o Código de Endereçamento Postal (CEP) de cada associado participante;

d.2) a Ata deverá estar devidamente registrada no Cartório de Registro de Títulos e Documentos e declarar, de forma clara e expressa, que todos os associados participantes estão em dia com suas obrigações estatutárias.

7.3. A documentação deverá ser apresentada no original ou em cópia autenticada, não sendo exigido o reconhecimento de firma, excetuados os casos em que haja dúvida de autenticidade, conforme o disposto na Lei n. ${ }^{\circ} 9.784$ de 29 de janeiro de 1999, que regula o processo administrativo no âmbito da Administração Pública Federal. 


\section{REQUISITOS BÁSICOS PARA ANÁLISE}

8.1. A tramitação dos requerimentos obedecerá à ordem cronológica de publicação dos Avisos.

8.2. As fundações e associações comunitárias interessadas em executar o Serviço de Radiodifusão Comunitária deverão atender os seguintes requisitos:

a) estar legalmente instituídas e devidamente registradas;

b) ter a sede situada na área onde pretendem executar o Serviço, exceto nas localidades de pequeno porte, onde poderão estar sediadas em qualquer ponto da área urbana; c) ser dirigidas por pessoas naturais brasileiras, natas ou naturalizadas há mais de dez anos, com capacidade civil plena e que mantenham residência na área de execução do Serviço, exceto nas localidades de pequeno porte, onde poderão residir em qualquer ponto da área urbana;

d) não ser detentoras de outorga para a execução de qualquer outra modalidade de serviço de radiodifusão ou de serviços de distribuição de sinais de televisão por assinatura, bem como não ter, entre seus dirigentes ou associados, pessoas que, nessas condições, participem de outras entidades detentoras de outorga para execução de qualquer dos serviços mencionados;

e) ter caráter comunitário, entendendo-se como entidade comunitária, para o fim de execução do Serviço, que a requerente deva expressar um projeto de construção coletiva de unidade na diversidade, por meio das seguintes características:

e.1) ser especificamente voltada para a execução do Serviço de Radiodifusão Comunitária ou, caso seja entidade também dedicada a outros fins, inclua a execução do Serviço como uma das suas finalidades específicas, observando os princípios estabelecidos no art. 4o da Lei ${ }^{\circ}$ 9.612, de 1998;

e.2) assegurar o ingresso, como associado, de todo e qualquer cidadão domiciliado na área de execução do Serviço, bem como de outras entidades sem fins lucrativos nela sediadas;

e.3) assegurar a seus associados o direito de votar e ser votado para todos os cargos de direção, bem como o direito de voz e voto nas deliberações sobre a vida social da entidade, nas instâncias deliberativas existentes;

f) não manter vínculos que a subordinem ou a sujeitem à gerência, à administração, ao domínio, ao comando ou à orientação de qualquer outra entidade, mediante compromissos ou relações financeiras, religiosas, familiares, político-partidárias ou comerciais; e

g) ter o local proposto para a instalação do sistema irradiante situado de modo que assegure uma relação de proteção (sinal desejado/sinal interferente) entre emissoras do Serviço de Radiodifusão Comunitária que ocupem o mesmo canal, de no mínimo 25 dB, nas áreas de execução de Serviço delimitadas pelo contorno de $91 \mathrm{~dB}$ |, aproximadamente um quilômetro, considerando-se que a separação mínima exigida entre as estações será de quatro quilômetros.

\section{PROCEDIMENTOS PARA ANÁLISE}

9.1. A análise será procedida com a finalidade de averiguar a regularidade da documentação apresentada pela entidade requerente, bem como a sua adequação ao conceito de entidade comunitária.

9.2. A constatação de irregularidades na documentação instrutória dos pedidos poderá 
levar a Secretaria de Serviços de Comunicação Eletrônica a adotar uma das medidas previstas a seguir:

a) solicitar à entidade o atendimento a exigências formuladas em razão de irregularidades passíveis de saneamento, que possam ser resolvidas mediante retificação dos documentos encaminhados ou por acréscimo de novos documentos; e b) comunicar o arquivamento do pedido de autorização, frente à incompatibilidade da entidade com as exigências legais.

9.3 A Secretaria de Serviços de Comunicação Eletrônica, no que se refere aos ofícios com exigências encaminhados às entidades requerentes durante o procedimento de análise, observará:

a) a comprovação do recebimento do ofício pela entidade requerente, por meio do AR Postal;

b) a fixação de um prazo de resposta de 20 (vinte) dias contados a partir da data do recebimento, podendo ser prorrogado por igual período, uma única vez, desde que a entidade solicite a dilatação do prazo antes de seu término; e

c) a publicação no Diário Oficial da União e sua veiculação pela Internet, no endereço www.mc.gov.br, arquivando-se o processo, nos casos em que o ofício não for respondido no prazo estabelecido ou for devolvido pelos Correios por impossibilidade de localização do endereço indicado.

9.4. A Secretaria de Serviços de Comunicação Eletrônica analisará as manifestações de apoio atribuindo-lhes pontuação, calculada de acordo com a seguinte ponderação:

a) a cada manifestação de apoio encaminhada, individualmente, por pessoa natural será atribuído o valor de um ponto;

b) a cada manifestação de apoio, de pessoa natural, constante de abaixo-assinado, será atribuído o valor de um ponto por assinante;

c) a cada manifestação de apoio encaminhada por associação representativa da comunidade a ser atendida será atribuído o valor de cinco pontos, independentemente do número de associados; e

d) a cada manifestação de apoio dos associados integrantes da entidade requerente será atribuído o valor de dois pontos, por associado.

9.5. A Secretaria de Serviços de Comunicação Eletrônica divulgará, no Diário Oficial da União, na Internet e, ainda, comunicará aos interessados, via postal, quais as entidades participantes, por área de execução do serviço, informando a pontuação ponderada das manifestações de apoio apresentadas por entidade.

9.6. A análise será concluída com a habilitação das entidades participantes do procedimento seletivo, considerando os requisitos técnicos e jurídicos.

9.7. Da análise poderá também decorrer o arquivamento do pedido de autorização cuja documentação instrutória não atenda aos requisitos técnicos e jurídicos estabelecidos nesta Norma..

9.7.1. O arquivamento será determinado pelo Secretário de Serviços de Comunicação Eletrônica, precedido de parecer do Diretor do Departamento de Outorga de Serviços;

9.7.2. O arquivamento do pedido será comunicado à entidade requerente, explicitandose as razões da decisão adotada, mediante ofício enviado por AR Postal. 
9.7.3. Do arquivamento do pedido caberá solicitação de revisão da decisão, no prazo máximo de trinta dias contados a partir da data de recebimento do comunicado de arquivamento.

9.7.4. A revisão de decisão do arquivamento será indeferida nas seguintes situações:

a) quando as razões apresentadas pela requerente forem insuficientes para modificar a decisão que levou ao arquivamento;

b) no caso de o pedido de revisão ter sido apresentado intempestivamente

c) quando o pedido for formulado por quem não possua legitimidade para fazê-lo;

d) após exauridas as esferas administrativas.

\section{DA SELEÇÃO DA ENTIDADE HABILITADA}

10.1. Se apenas uma entidade se habilitar para a execução do Serviço, estando regular a documentação apresentada, o Ministério das Comunicações expedirá autorização à referida entidade.

10.2. Havendo mais de uma entidade habilitada para a execução do Serviço na mesma área de interesse, será concedido prazo de trinta dias para que essas entidades se associem, visando à exploração em comum do Serviço.

10.3. Findo o prazo assinalado, e:

a) havendo manifestação favorável ao acordo entre as entidades com interesse na mesma área de execução do Serviço, será acolhida a proposta de associação entre elas; e b) não havendo manifestação favorável ao acordo para associação, será selecionada a entidade que tiver apresentado a maior pontuação ponderada de manifestações de apoio.

10.4. Havendo igual representatividade entre as entidades, proceder-se-á a escolha por sorteio, em local público, na sede do Ministério das Comunicações, com a presença de, no mínimo, dois servidores, e para o qual serão convidadas as entidades interessadas.

\section{DO ASSENTIMENTO PRÉVIO PARA A EXECUÇÃO DO SERVIÇO NA FAIXA DE FRONTEIRA}

11.1. Caso a entidade selecionada pretenda instalar a estação em localidades distantes até cento e cinqüenta quilômetros da fronteira com outros países, deverá ser obtido, para essa finalidade, assentimento prévio junto ao Conselho de Defesa Nacional.

11.2. Para obtenção da autorização a que se refere o subitem 11.1, a entidade selecionada deverá enviar ao Ministério das Comunicações requerimento dirigido ao Secretário-Executivo do Conselho de Defesa Nacional da Presidência da República, solicitando o assentimento prévio para instalar a estação de Radiodifusão Comunitária na localidade pretendida, em conformidade com a Lei $\mathrm{n}^{0}$ 6.634, de 2 de maio de 1979 e o Decreto no 85.064, de 26 de agosto de 1980.

11.3. O requerimento deverá ser instruído com a seguinte documentação:

a) cópia autenticada do Estatuto Social da entidade, e suas alterações em que constem artigos dispondo que:

a.1) a responsabilidade e a orientação intelectual e administrativa da entidade caberão sempre 
a brasileiros natos ou naturalizados há mais de dez anos;

a.2) o quadro de pessoal será constituído de, pelo menos, dois terços de trabalhadores brasileiros;

a.3) a entidade não poderá efetuar nenhuma alteração do seu Estatuto Social sem prévia autorização da Secretaria Executiva do Conselho de Defesa Nacional;

b) prova de nacionalidade de todos os dirigentes (cópia da certidão de nascimento para os solteiros, cópia da certidão de casamento para os casados, cópia de certidão de casamento com a correspondente averbação para os separados judicialmente ou divorciados, e cópia da certidão de casamento e de óbito do cônjuge, para os viúvos);

c) prova de que os dirigentes estão em dia com as obrigações referentes ao serviço militar; e

d) prova de que os dirigentes estão em dia com as obrigações relacionadas com a Justiça Eleitoral.

11.4. A solicitação de assentimento prévio exige abertura de um novo processo, com um novo número, diferente do requerimento para execução do Serviço de Radiodifusão Comunitária.

11.5. O assentimento prévio, dado pela Secretaria Executiva do Conselho de Defesa Nacional, para instalação de estação em localidade situada na faixa de fronteira, é condição imprescindível para que a autorização para executar Serviço de Radiodifusão Comunitária seja outorgada.

\section{DA APRESENTAÇÃO DO PROJETO TÉCNICO}

12.1. Após a seleção, a entidade selecionada deverá apresentar ao Ministério das Comunicações, no prazo de trinta dias, projeto técnico para a instalação da estação, conforme a seguir estabelecido:

a) formulário padronizado, devidamente preenchido, contendo as características técnicas de instalação e de operação da estação;

b) declaração firmada pelo representante legal da entidade de que:

b.1) na ocorrência de interferências prejudiciais causadas pela estação, interromperá imediatamente suas transmissões até que essas sejam sanadas;

b.2) na ocorrência de interferências indesejáveis causadas pela estação, caso essas não sejam sanadas no prazo estipulado pela ANATEL, interromperá suas transmissões; c) planta de arruamento em escala compatível com a área da localidade objeto da outorga, que permita a visualização do nome das ruas, onde deverão estar assinalados o local de instalação do sistema irradiante, com indicação das coordenadas geográficas na forma $\mathrm{GG}^{\circ} \mathrm{MM}^{\prime}$ 'SS”, o traçado de circunferência de até um quilômetro de raio, que delimita a área abrangida pelo contorno de $91 \mathrm{~dB}$ |, e o local da sede da entidade; d) diagrama de irradiação horizontal da antena transmissora, com a indicação do Norte Verdadeiro; diagrama de irradiação vertical e especificações técnicas do sistema irradiante proposto; no caso de antenas de polarização circular ou elíptica, devem ser apresentadas curvas distintas das componentes horizontal e vertical dos diagramas; e) declaração do profissional habilitado de que a cota do terreno, no local de instalação do sistema irradiante, atende as condições exigidas no item 18.2.7.1 ou estudo específico, conforme determina o item 18.2.7.1.1;

f) declaração do profissional habilitado atestando que a instalação proposta não fere os 
gabaritos de proteção aos aeródromos, ou declaração do órgão competente do Ministério da Aeronáutica autorizando a instalação proposta, ou, se for o caso, declaração de inexistência de aeródromos na localidade;

g) parecer conclusivo, assinado pelo profissional habilitado, atestando que a instalação proposta atende a todas as exigências das normas técnicas em vigor aplicáveis à mesma e que o contorno de $91 \mathrm{~dB}$ / da emissora não fica situado a mais de um quilômetro de distância da antena transmissora em nenhuma direção; e

h) anotação de Responsabilidade Técnica - ART referente à instalação proposta.

\section{DA AUTORIZAÇÃO PARA EXECUTAR O SERVIÇO}

13.1. A autorização para a execução do Serviço de Radiodifusão Comunitária é outorgada mediante portaria do Ministro de Estado das Comunicações.

13.1.1. O Ministério das Comunicações publicará no Diário Oficial da União e disponibilizará na Internet, no endereço www.mc.gov.br., o resumo da autorização de que trata este subitem.

13.2. A portaria ministerial que formalizará a autorização deverá indicar:

a) a denominação da entidade;

b) o endereço da sede da entidade;

c) a localidade e o Estado;

d) o objeto e o prazo da autorização;

e) as coordenadas geográficas; e

f) a freqüência de operação.

13.3. O ato de autorização somente produzirá efeitos legais após deliberação do Congresso Nacional, nos termos do $\S 3^{\circ}$ do art. 223 da Constituição Federal.

13.4. Em localidades cuja área urbana estiver circunscrita a um círculo com raio menor ou igual a quatro quilômetros, somente será expedida uma autorização para executar o Serviço de Radiodifusão Comunitária.

13.5. Em localidades que não se enquadrem como de pequeno porte, nos termos do inciso II, do art. $8^{\circ}$, do Decreto $n^{\circ} 2.615$, de 3 de junho de 1998 , poderá ser admitida mais de uma emissora, desde que atendido o disposto no subitem 18.2.10.

\section{DA INSTALAÇÃO DA ESTAÇÃO}

14.1. A instalação da estação deverá atender às disposições estabelecidas no item 18 desta Norma e deverá estar de acordo com os dados constantes do formulário mencionado na alínea "a” do subitem 12.1.

14.2. Qualquer alteração na instalação da estação que implique modificação dos dados informados deverá ser submetida à prévia anuência do Ministério das Comunicações em formulário padronizado.

14.2.1. A alteração do local de instalação da estação somente poderá ocorrer se o novo local estiver circunscrito em um raio de até 1 (um) Km das coordenadas geográficas constantes da portaria de autorização da execução do serviço. 
14.3. O prazo para o início efetivo da execução do Serviço de Radiodifusão Comunitária é de seis meses a contar da data de vigência do ato de autorização de operação em caráter provisório ou da licença para funcionamento da estação, não podendo ser prorrogado.

14.4. Caso a entidade tenha interesse em testar os equipamentos antes do início efetivo da execução do Serviço, uma vez concluída a instalação da estação, poderá operar em caráter experimental, pelo período máximo de trinta dias, desde que comunique o fato ao Ministério das Comunicações, com antecedência mínima de cinco dias úteis.

\section{DA AUTORIZAÇÃO DE OPERAÇÃO EM CARÁTER PROVISÓRIO}

15.1. Autorizada a execução do serviço e, transcorrido o prazo previsto no art. 64 , $\S \S 2^{\circ}$ e $4^{\circ}$ da Constituição, sem apreciação do Congresso Nacional, o Ministério das Comunicações expedirá autorização de operação, em caráter provisório, que perdurará até a publicação do Decreto Legislativo expedido pelo Congresso Nacional.

15.2. Da autorização de operação em caráter provisório deverão constar as informações mencionadas nas alíneas do subitem 16.2.

\section{DA LICENÇA PARA FUNCIONAMENTO DE ESTAÇÃO}

16.1. Após a deliberação pelo Congresso Nacional e a expedição de Decreto Legislativo, o Ministério das Comunicações emitirá a licença para funcionamento de estação, com prazo de vigência de dez anos.

16.2. Da licença para funcionamento de estação, deverá constar, pelo menos:

a) denominação da entidade;

b) denominação de fantasia da emissora;

c) número do Fistel;

d) número da estação;

e) CNPJ;

f) número do processo;

g) coordenadas geográficas do sistema irradiante;

h) endereço da estação ou local de operação;

i) raio da área de serviço;

j) horário de funcionamento;

l) canal e freqüência de operação;

m) indicativo de chamada;

n) fabricante, modelo e código de certificação do transmissor;

o) potência de operação do transmissor;

p) polarização, ganho e altura da antena transmissora em relação ao solo;

q) informação de que a emissora não tem direito a proteção contra interferências causadas por estações de telecomunicações e de radiodifusão regularmente instaladas.

\section{DA OPERAÇÃO DA ESTAÇÃO}

17.1. Iniciada a operação da estação, em caráter provisório ou definitivo, a entidade autorizada comunicará o fato à ANATEL, no prazo máximo de cinco dias úteis, cabendo a esta proceder à vistoria. 
17.2. Qualquer alteração na estação, que implique modificação nos dados constantes da autorização de operação em caráter provisório, ou da licença para funcionamento de estação, será objeto de emissão de nova autorização de operação ou de nova licença, uma vez comprovado o recolhimento da correspondente taxa de fiscalização da instalação.

\section{DAS CARACTERÍSTICAS TÉCNICAS DA ESTAÇÃO}

\subsection{DA EMISSÃO}

\subsubsection{Designação: monofônica: 180KF3EGN estereofônica: 256KF8EHF}

18.1.2. Polarização: a polarização da onda eletromagnética emitida pela antena poderá ser linear (horizontal ou vertical), circular ou elíptica.

18.1.3. Tolerância de freqüência: a freqüência central da estação de radiodifusão comunitária não poderá variar mais que $\pm 2000 \mathrm{~Hz}$ de seu valor nominal.

18.1.4. Espúrios de radiofreqüência: qualquer emissão presente em freqüências afastadas de 120 a $240 \mathrm{kHz}$, inclusive, da freqüência da portadora deverá estar pelo menos 25 dB abaixo do nível da portadora sem modulação; as emissões em freqüências afastadas de mais de $240 \mathrm{kHz}$ até $600 \mathrm{kHz}$, inclusive, da freqüência da portadora deverão estar pelo menos 35 dB abaixo do nível da portadora sem modulação; as emissões em freqüências afastadas de mais de $600 \mathrm{kHz}$ da freqüência da portadora deverão estar pelo menos $(73+\mathrm{P}) \mathrm{dB}(\mathrm{P}=$ potência de operação do transmissor, em dBk) abaixo do nível da portadora sem modulação.

18.1.5. É estabelecida a referência de $75 \mathrm{kHz}$ no desvio de freqüência da portadora para definir o nível de modulação de $100 \%$.

\subsection{DAS EMISSORAS}

18.2.1. A potência efetiva irradiada - ERP por emissora do Serviço de Radiodifusão Comunitária será de, no máximo, 25 watts.

18.2.2. O máximo valor de intensidade de campo que a estação poderá ter a uma distância de um quilômetro da antena e a uma altura de 10 metros sobre o solo será de $91 \mathrm{~dB}$ (, obtido a partir da expressão: $\mathrm{E}(\mathrm{dB} \mid)=107+\mathrm{ERP}(\mathrm{dBk})-20 \log \mathrm{d}(\mathrm{km})$, onde: ERP (dBk) - potência efetiva irradiada, em dB relativos a $1 \mathrm{~kW}$ (tomado o valor máximo, de - $16 \mathrm{dBk}$, correspondentes a $25 \mathrm{~W})$, sendo: $\mathrm{ERP}(\mathrm{dBk})=10 \log (\mathrm{Pt} x \mathrm{Ght} x$ Gvt $\mathrm{x} \mid$ ), em que: Pt - potência do transmissor, em $\mathrm{kW}$; Ght - ganho da antena, no plano horizontal, em relação ao dipolo de meia onda, em vezes; Gvt - ganho da antena, no plano vertical, em relação ao dipolo de meia onda, em vezes; - eficiência da linha de transmissão; d - distância da antena transmissora ao limite da área de serviço, em km, (tomado o valor máximo de um $\mathrm{km}$ ). Em nenhuma direção o valor da intensidade de campo, a um quilômetro, poderá ser superior à indicada no item 18.2.2.

18.2.3. A área de serviço de uma emissora do Serviço de Radiodifusão Comunitária é aquela limitada por uma circunferência de raio igual ou inferior a mil metros, a partir da 
antena transmissora, e será estabelecida de acordo com a área da comunidade servida pela estação.

18.2.4. O sistema irradiante de estação do Serviço de Radiodifusão Comunitária deverá estar localizado, preferencialmente, no centro da área de serviço da emissora.

18.2.5. O diagrama de irradiação da antena utilizada por estação do Serviço de Radiodifusão Comunitária deverá ser omnidirecional.

18.2.6. O ganho da antena transmissora será de, no máximo, 0 dB, em relação ao dipolo de meia onda.

18.2.7. A altura da antena com relação ao solo será de, no máximo, trinta metros.

18.2.7.1. A cota do terreno (solo), no local de instalação do sistema irradiante, não poderá ser superior a trinta metros, com relação à cota de qualquer ponto do terreno no raio de um km em torno do local do sistema irradiante.

18.2.7.1.1. Caso a condição estabelecida no subitem 18.2.7.1 não seja satisfeita, a instalação proposta será analisada como situação especial, mediante análise, caso a caso, de estudo específico que apresente as peculiaridades do terreno, com levantamento das cotas num raio de até quatro quilômetros, e no qual fique demonstrada a adequada execução do serviço na área a ser atendida, sem acréscimo dos valores de intensidade de campo sobre áreas de serviço de estações de radiodifusão comunitária ocupando o mesmo canal.

18.2.8. A ligação entre o transmissor e a antena deve ser feita por meio de cabo coaxial.

18.2.9. O estúdio e o transmissor devem estar instalados, preferencialmente, na mesma edificação, não sendo permitida a instalação de estúdio auxiliar.

18.2.9.1. No caso em que o estúdio e o transmissor não estejam instalados na mesma edificação, o uso de freqüências destinadas aos serviços auxiliares de radiodifusão e correlatos, somente será autorizado, em caráter excepcional, em caso de interferência comprovada na recepção de televisão.

18.2.10. A separação mínima entre duas estações do Serviço de Radiodifusão Comunitária será de quatro quilômetros.

18.2.11. É vedada, às estações do Serviço de Radiodifusão Comunitária, a transmissão no canal secundário prevista no item 3.2.9. do Regulamento Técnico para Emissoras de Radiodifusão Sonora em Freqüência Modulada, aprovado pela Resolução Anatel n 67, de 12 de novembro de 1998.

\subsection{DOS TRANSMISSORES}

18.3.1. Somente será permitida a utilização de equipamentos transmissores certificados pela ANATEL. 
18.3.1.1. Os equipamentos transmissores utilizados no Serviço de Radiodifusão Comunitária deverão ser pré-sintonizados na freqüência de operação consignada à emissora e deverão ter sua potência de saída inibida à potência de operação constante da Licença para Funcionamento de Estação.

18.3.2. As especificações dos transmissores deverão atender os requisitos mínimos a seguir indicados.

18.3.2.1. Os transmissores não poderão ter dispositivos externos que permitam a alteração da freqüência e da potência de operação.

18.3.2.2. Os transmissores devem estar completamente encerrados em gabinete metálico e todas as partes expostas ao contato dos operadores serão eletricamente interligadas e conectadas à terra.

18.3.3. Todo o transmissor deve ter fixada no gabinete uma placa de identificação onde conste, no mínimo, o nome do fabricante, o número de série, a potência nominal e a freqüência de operação.

18.3.4. O dispositivo de controle da freqüência deve ser tal que permita a manutenção automática da freqüência de operação entre os limites de mais ou menos $2000 \mathrm{~Hz}$ da freqüência nominal.

18.3.5. Qualquer emissão presente em freqüências afastadas de 120 a $240 \mathrm{kHz}$ (inclusive) da freqüência da portadora deverá estar pelo menos 25 dB abaixo do nível da portadora sem modulação.

18.3.6. As emissões em freqüências afastadas da freqüência da portadora de $240 \mathrm{kHz}$ até $600 \mathrm{kHz}$, inclusive, deverão estar pelo menos 35 dB abaixo do nível da portadora sem modulação.

18.3.7. As emissões em freqüências afastadas de mais de $600 \mathrm{kHz}$ da freqüência da portadora deverão estar abaixo do nível da portadora sem modulação de $(73+P) d B$, onde P é a potência de operação do transmissor em dBk.

18.3.8. A distorção harmônica total das freqüências de áudio, introduzidas pelo transmissor, não deve ultrapassar o valor eficaz de 3\% na faixa de 50 a $15.000 \mathrm{~Hz}$ para percentagens de modulação de 25, 50 e 100\%.

18.3.9. O nível de ruído, por modulação em freqüência, medido na saída do transmissor, na faixa de 50 a $15.000 \mathrm{~Hz}$, deverá estar, pelo menos, $50 \mathrm{~dB}$ abaixo do nível correspondente a $100 \%$ de modulação da portadora por um sinal senoidal de $400 \mathrm{~Hz}$. 18.3.10. O nível de ruído, por modulação em amplitude, medido na saída do transmissor, na faixa de 50 a $15.000 \mathrm{~Hz}$, deverá estar, pelo menos, $50 \mathrm{~dB}$ abaixo do nível que represente $100 \%$ de modulação em amplitude.

\section{DAS REGRAS GERAIS PARA A EXECUÇÃO DO SERVIÇO}

19.1. Toda estação de Serviço de Radiodifusão Comunitária é obrigada a irradiar seu indicativo de chamada a cada sessenta minutos. 
19.2. A entidade autorizada a executar o Serviço de Radiodifusão Comunitária deverá manter atualizado o endereço de sua sede, bem como o nome e o endereço residencial de cada um de seus dirigentes, para qualquer solicitação ou inspeção do Ministério das Comunicações.

19.3. Toda a irradiação deverá ser gravada e mantida em arquivo durante as vinte e quatro horas subseqüentes ao encerramento dos trabalhos diários da emissora, devendo também ser conservados em arquivo, durante sessenta dias, os textos dos programas, inclusive noticiosos, devidamente autenticados pelo responsável legal da entidade.

19.3.1. As gravações dos programas políticos, de debates, entrevistas, pronunciamentos da mesma natureza e qualquer irradiação não registrada em texto deverão ser conservadas em arquivo pelo prazo de vinte dias, a partir da transmissão.

19.3.2. As transmissões compulsoriamente estatuídas por lei serão gravadas em material fornecido pelos interessados.

19.4. A entidade autorizada a executar o Serviço de Radiodifusão Comunitária deverá instituir um Conselho Comunitário, composto por, no mínimo, cinco pessoas representantes de entidades da comunidade local ou, nos casos enquadrados no subitem 13.5, da área urbana da localidade, tais como associações de classe, beneméritas, religiosas ou de moradores, desde que legalmente instituídas, com o objetivo de acompanhar a programação da emissora, com vista ao atendimento do interesse exclusivo da comunidade e dos princípios estabelecidos no art. $4^{\circ}$ da Lei n. ${ }^{\circ} 9.612$, de 1998.

19.4.1. O Conselho Comunitário deverá encaminhar ao Ministério das Comunicações, anualmente, sempre na data de aniversário da outorga, relatório resumido contendo a descrição da grade de programação, bem como sua avaliação considerando, entre outros aspectos, o atendimento dos objetivos estabelecidos no subitem 19.4.

19.4.2. A entidade deverá manter disponível e atualizado, para qualquer solicitação ou inspeção do Ministério das Comunicações, o ato que estabeleceu a composição do Conselho Comunitário.

19.5. As emissoras do Serviço de Radiodifusão Comunitária assegurarão, em sua programação, espaço para divulgação de planos e realizações de entidades ligadas, por suas finalidades, ao desenvolvimento da comunidade.

19.6. As entidades autorizadas para execução do Serviço de Radiodifusão Comunitária poderão admitir patrocínio, sob a forma de apoio cultural, para os programas a serem transmitidos, desde que restritos aos estabelecimentos situados na área da comunidade atendida.

19.6.1. Entende-se por apoio cultural o pagamento dos custos relativos a transmissão da programação ou de um programa específico, mediante a divulgação de mensagens institucionais da entidade apoiadora. 


\section{Bibliografia}

BOTWINICK, Aryeh; BACHRACH, Peter. Democracy and Scarcity: Toward a Theory of Participatory Democracy. International Political Science Review, Vol. 4, No. 3. [S.l.], 1983, p. 361-373.

BRANDÃO, Assis. Bobbio na história das idéias democráticas. Lua Nova, $\mathrm{n}^{\circ}$ 68. São Paulo: 2006, p. 123 a 145.

BRASIL, Kátia. Garis dão dicas sobre coleta de lixo pelo rádio no AM. Folha de São Paulo, $20 \quad$ dez. 2005.2 Disponível em <http://www1.folha.uol.com.br/folha/cotidiano/ult95u116452.shtml>. Acesso em 25 de agosto de 2008

CÂMARA DOS DEPUTADOS. (2003-2006), Discursos proferidos em plenário. Disponível em <http://www2.camara.gov.br/internet/plenario/discursos $>$. Acessos entre julho e dezembro de 2007.

CARRION, Eduardo K. M. A Respeito da Democracia Participativa in J. Soares (coord.), Estudos de Direito Constitucional: homenagem a Paulo Bonavides. São Paulo: LTr, 2001.

CORREIO BRASILIENSE (2002). Rádios Comunitárias. Notícia publicada em 1/10/2002. Disponível em <http://buscacb2.correioweb.com.br/correio/2002/10/01/G20110.PDF.pdf>. Acesso em 26 de agosto de 2008.

DEXHEIMER, Marcus Alexsander. Estatuto da Cidade e Democracia Participativa. Florianópolis: OAB/SC Editora, 2006.

FERNANDES, Luis. Muito Barulho por Nada? O realinhamento Político Ideológico nas Eleições de 1994. Dados, vol. 38, nº 1. Rio de Janeiro: 1995, p. 107 a 144.

FOLHA ONLINE (2007a). Prefeitura de SP derruba torre que transmitia sinais de rádios pirata. Notícia publicada em 23/10/2007. Disponível em <http://www1.folha.uol.com.br/folha/cotidiano/ult95u339209.shtml>. Acesso em 19 de agosto de 2008.

FOLHA ONLINE (2007b). Prefeitura e Anatel fecham duas rádios piratas em São Paulo. Notícia publicada em 22/11/2007. Disponível em $<$ http://www1.folha.uol.com.br/folha/cotidiano/ult95u347891.shtml>. Acesso em 19 de agosto de 2008.

FOLHA ONLINE (2008). Polícia fecha quatro rádios piratas e detém dois em Osasco (SP). Notícia publicada em 12/04/2008. Disponível em <http://www1.folha.uol.com.br/folha/cotidiano/ult95u391464.shtml>. Acesso em 19 de agosto de 2008. 
FREITAS, Clayton. Polícia Civil e Anatel fecham dez rádios piratas; oito são detidos. Folha de São Paulo, 6 jun. 2007. Disponível em $<$ http://www1.folha.uol.com.br/folha/cotidiano/ult95u302518.shtml>. Acesso em 19 de agosto de 2008.

GABARDI, Wayne. Contemporary Models of Democracy. Polity, Vol. 33, No. 4. [S.1.], 2001, p. 547 a 568.

GARCIA, José Carlos. O princípio democrático na Constituição de 1988. Revista de Direito da Defensoria Pública, Rio de Janeiro, ano 11, nº 15, 1999.

GOBBI, Nelson. O protesto das rádios. JB Online, 20 out. 2005. Disponível em <http://quest1.jb.com.br/jb/papel/cadernob/2005/10/19/jorcab20051019007.html>. Acesso em 19 de agosto de 2008.

GOULART, Guilherme; BERNARDES, Adriana. Interferência Pirata. Correio Brasiliense, Brasília, 23 nov. 2005. Caderno cidades, p. 28.

GRAMACHO, Wladimir. Pimenta da Veiga distribui rádios a aliados em MG. Folha de São Paulo, 212 out. 2001. Disponível em <http://www1.folha.uol.com.br/folha/brasil/ult96u25908.shtml>. Acesso em 28 de agosto de 2008.

HONNETH, Axel; FARRELL, John. M. M. Democracy as Reflexive Cooperation: John Dewey and The Teory of Democracy Today. Political Theory, Vol. 26, No. 6. [S.1], 1998, p. 763 a 783.

IGREJA, Gustavo. Rádios comunitárias ferem legislação. JB ONLINE, 3 mai. 2004. Disponível em <http://quest1.jb.com.br/jb/papel/brasilia/2004/05/02/jorbrs20040502004.html>. Acesso em 19 de setembro de 2008.

JB ONLINE (2005). Anvisa renova parceria com rádios comunitárias. Notícia publicada em 03/06/2005. Disponível em <http://quest1.jb.com.br/extra/2005/06/03/e03061209.html>. Acesso em 26 de agosto de 2008.

JB ONLINE (2007a). Novo edital de rádios comunitárias quer atender comunidades isoladas. Notícia publicada em 11/4/2007. Disponível em <http:/quest1.jb.com.br/extra/2007/04/11/e110430170.html>. Acesso em 23 de setembro de 2008.

JB ONLINE (2007b). Pesquisador cobra transparência em concessões de rádio e TV. Notícia publicada em 05/09/2007. Disponível em $<$ http://quest1.jb.com.br/extra/2007/09/05/e05096499.html>. Acesso em 28 de agosto de 2008.

JB ONLINE (2007c). Rádios comunitárias reclamam da demora para obter licença. Notícia publicada em 9/12/2007. Disponível em 
<http://quest1.jb.com.br/extra/2007/12/09/e09126548.html>. Acesso em 23 de setembro de 2008.

JB ONLINE (2008). Rádio Comunitária de Heliópolis é a primeira de São Paulo autorizada. Notícia publicada em 21/05/2008. Disponível em $<$ http://quest1.jb.com.br/extra/2008/05/21/e210521085.html>. Acesso em 14 de outubro de 2008.

KAUFMAN-OSBORN, Timothy V. John Dewey and the Liberal Science of Community. The Journal of Politics, Vol. 46, No. 4. [S.1], 1984, p. 1142 a 1165.

LIMA, Venício Artur de; LOPES, Cristiano Aguiar. Rádios comunitárias: coronelismo eletrônico de novo tipo (1999-2004). São Paulo: Observatório da Imprensa, 2007.

KINZO, MARIA D'ALVA G.. A democratização brasileira: um balanço do processo político desde a transição. São Paulo Perspec., São Paulo, v. 15, n. 4, 2001. Disponível em: $<$ http://www.scielo.br/scielo.php?script=sci_arttext\&pid=S010288392001000400002\&l ng=pt\&nrm=iso $>$. Acesso em: 04 Maio 2008. doi: 10.1590/S010288392001000400002.

LOBATO, Elvira. União Desvia R\$ 16 bi de telecomunicações. Folha de São Paulo, 15 out. $2006 . \quad$ Disponível em <http://www1.folha.uol.com.br/folha/dinheiro/ult91u111664.shtml>. Acesso em 14 de outubro de 2008.

MANSBRIDGE, Jane. Beyond Adversary Democracy. Chicago: The University of Chicago Press, 1983.

MATTOS, Laura. Polícia Federal e Anatel fecham rádio comunitária na Paraíba. Folha de São Paulo, 22 jan. 2003. Disponível em <http://www1.folha.uol.com.br/folha/ilustrada/ult90u30165.shtml>. Acesso em 19 de agosto de 2008.

MATTOS, Laura. Outra Freqüência: Na era Lula, sobe o número de rádios fechadas. Folha de São Paulo, 28 jan. 2004. Disponível em <http://www1.folha.uol.com.br/folha/ilustrada/ult90u40920.shtml>. Acesso em 19 de agosto de 2008.

MAZZINI, Leandro. Rádios comunitárias na mira da Câmara. JB ONLINE, 19 jun. $2007 . \quad$ Disponível em <http://quest1.jb.com.br/editorias/pais/papel/2007/06/19/pais20070619009.html>. Acesso em 9 de outubro de 2008.

MELTZ, Joseph G. Democracy and the Scientific Method in the Philosophy of John Dewey. The Review of Politics, Vol. 31, No. 2. [S.1], 1969, p. 242 a 262

MIGUEL, Luis Felipe. A democracia domesticada: Bases Antidemocráticas do Pensamento Democrático Contemporâneo. DADOS - Revista de Ciências Sociais, Vol. 45, n 3. Rio de Janeiro: 2002, p. 483 a 511. 
MORRIS, Debra. "How Shall We Read What We Call Reality?": John Dewey's New Science of Democracy. American Journal of Political Science, Vol. 43, No. 2. [S.1], 1999, p. 608-628.

POGREBINSCHI, Thamy. A democracia do homem comum: resgatando a teoria política de John Dewey. Rev. Sociol. Polit., n² 23. Curitiba: 2004, p. 43 a 53.

RODRIGUES, Leôncio Martins. Partidos, Ideologia e Composição Social. São Paulo: Edusp, 2002.

SILVEIRA, Paulo Fernando. Rádios Comunitárias. Belo Horizonte: Del Rey, 2001.

SCHUMPETER, Joseph. Capitalismo, socialismo e democracia. Rio de Janeiro: Zahar, 1984.

VITULLO, Gabriel. Representação e democracia representativa: dois conceitos indissociáveis? III Seminário de Ciência Política da UFPE, 2007. Disponível em $<$ http://seminariopolitica.t5.com.br/papers/gabrielvitulo.doc $>$. Acesso em 30 de junho de 2008.

WHIPPLE, Mark. The Dewey-Lippmann Debate Today: Communication Distortions, Reflective Agency, and Participatory Democracy. Sociological Theory, Vol. 23, No. 2. [S.1.], 2005, p. 156-178.

WOLFE, Joel D. A Defense of Participatory Democracy. The Review of Politics, Vol. 47, No. 3. [S.1.], 1985, pp. 370-389.

ZERO HORA (2006). São Vicente do Sul-RS Prefeito é cassado por vereadores. Notícia publicada em 19/07/2006. Disponível em $<$ http://www.amarribo.org.br/mambo/index.php?option=com_content\&task=view\&id=8 03\&Itemid=82>. Acesso em 28/08/2008. 